\title{
Mortgage Rates, Household Balance Sheets, and the Real Economy
}

\author{
Benjamin J. Keys, University of Chicago* \\ Tomasz Piskorski, Columbia Business School \\ Amit Seru, University of Chicago and NBER \\ Vincent Yao, Fannie Mae
}

September 2014

\begin{abstract}
This paper investigates the impact of lower mortgage rates on household balance sheets and other economic outcomes during the housing crisis. We use proprietary loan-level panel data matched to consumer credit records using borrowers' Social Security numbers, which allows for accurate measurement of the effects. Our main focus is on borrowers with agency loans, which constitute the vast majority of U.S. mortgage borrowers. Using a difference-in-differences framework that exploits variation in the timing of rate resets of adjustable rate mortgages with different fixed-rate periods, we find that a sizable decline in mortgage payments (\$150 per month on average) induces a significant drop in mortgage defaults, an increase in new financing of durable consumption (auto purchases) of more than $10 \%$ in relative terms, and an overall improvement in household credit standing. We identify important heterogeneity in the ability of monetary policy to stimulate households' consumption: Low-wealth borrowers are especially responsive to reductions in mortgage payments, while credit-constrained households use more than $70 \%$ of their increased liquidity to deleverage, dampening their consumption response. These findings also qualitatively hold in a sample of less-prevalent borrowers with private nonagency loans. We then use regional variation in mortgage contract types to explore the impact of lower mortgage rates on broader economic outcomes. Regions more exposed to mortgage rate declines saw a relatively faster recovery in house prices, increased durable (auto) consumption, and increased employment growth, with responses concentrated in the non-tradable sector. Our findings have implications for the pass-through of monetary policy to the real economy through mortgage contracts and household balance sheets.
\end{abstract}

JEL Classification: D12, E20, E51, E65, G21

Keywords: Household Leverage, Crisis, Deleveraging, Monetary Policy, Mortgage Rates, Household Consumption, Adjustable-Rate Mortgages

\footnotetext{
* First version: March 2014. Keys thanks the Kreisman Program on Housing Law and Policy at the University of Chicago. Piskorski thanks National Science Foundation (Grant 1124188) and the Paul Milstein Center for Real Estate at Columbia Business School for financial support. Seru thanks the Fama Miller Center at Booth for financial support. We are grateful to Atif Mian and Amir Sufi for sharing their auto sales data. We thank Sumit Agarwal, Patrick Bolton, Jon Steinsson, Amir Sufi, Neng Wang, and seminar participants at Columbia Business School for helpful discussions. Zach Wade and Vivek Sampathkumar provided excellent research assistance. The views expressed in this research are those of the authors and do not necessarily represent the position of Fannie Mae.
} 


\section{Introduction}

There has been a long-standing debate among economists regarding the effects of monetary policy on the real economy (e.g., Bernanke and Gertler 1995). During the Great Recession, the Federal Reserve reduced short-term interest rates and made large purchases of mortgage-backed securities in an attempt to stimulate household spending and support the prices of assets such as houses. ${ }^{1}$ Remarkably, despite their economic importance, empirical evidence on the consequences of these extraordinary policy interventions is fairly limited. In this paper we aim to inform this debate by providing novel evidence on the impact of lower interest rates on mortgage borrowers and broader economic outcomes during the recent economic downturn.

Two challenges have confronted researchers who have tried to explore the effects of lower interest rates on a broad set of household choices: the availability of data and an empirical strategy to achieve credible identification. The first challenge reflects a general issue with consumer credit analysis-namely, that borrower credit outcomes exhibit substantial dispersion due to differences in creditworthiness, income, or location. Thus one needs a sufficiently large and representative sample with information on a rich array of consumer outcomes-such as monthly mortgage payments, outstanding credit card debt, and auto loan debt balances-to detect potential effects.

We address the first challenge by relying on a comprehensive proprietary dataset belonging to a large financial institution. This loan-level panel data on millions of U.S. mortgage borrowers in the agency market has detailed information on loan, property, and borrower characteristics and monthly payment history on mortgage debt. All records in this data have been matched to consumer credit bureau records using borrowers' Social Security numbers. This merge results in a highly accurate dataset of credit conditions and consumer debt spending patterns for each borrower, giving us more power to detect even small effects in noisy consumer credit measures. In addition, our sample is quite representative of the U.S. population, since the vast majority of mortgages in the U.S. are agency loans.

The second challenge confronting researchers studying the effects of lower interest rates on household choices is a credible research design. Factors that impact interest rates also typically

\footnotetext{
${ }^{1}$ See Stroebel and Taylor (2012) who discuss such interventions and estimate the impact of the mortgage-backed securities purchases by the Federal Reserve on mortgage interest rate spreads.
} 
affect households and economic outcomes through a variety of other mechanisms. In a crosssection of borrowers, households that face lower interest rates are usually more creditworthy, and hence their subsequent behavior may reflect their inherently strong credit profile and not just their lower cost of credit. Similarly, changes in interest rates over time are unlikely to be fully exogenous to the evolution of broader economic conditions.

We address this challenge by using a difference-in-differences framework to study the impact of mortgage rates on households' decisions. Our setting exploits variation in the timing of rate resets of adjustable rate mortgages, originated between 2003 and 2007, with different initial fixed-rate periods. The panel structure of our data allows us to use within-borrower variation before and after the rate resets. We focus on the recent period (late 2007 through 2012) in which the major interest rate indices, such as the LIBOR and one-year Treasury rates, experienced an unprecedented and rapid decline and subsequently remained low for an extended period of time. Due to the rate indexation of ARM contracts, borrowers whose rates reset during this period experienced sizable reductions in monthly mortgage payments. ${ }^{2}$ In contrast to prior studies that mostly study household responses to one-time income shocks, reductions in monthly mortgage debt servicing costs induce significant shocks to both current and expected future disposable income (up to the life of the loan).

In particular, we use the fact that 5/1 ARMs contracts have an initial five-year fixed rate period, while 7/1 ARMs have a seven-year fixed rate period (and reset annually thereafter). In months 61 and 73 of the loan's life, 5/1 ARMs reset to a new interest rate based on prevailing indices, while 7/1 ARMs remain in their fixed rate period. Consequently, monthly scheduled mortgage payments of 5/1 ARM borrowers - the treatment group -- fell on average by about $\$ 150$ per month (\$125 per month during the first year after the reset and \$163 per month during the second year, about a $20 \%$ relative reduction in monthly mortgage payments). These changes are measured relative to 7/1 ARM borrowers - the control group -- whose mortgage payments are unchanged prior to reaching their first rate reset. By comparing borrowers with ARMs of varying fixed-rate periods, we alleviate the selection concerns that could have affected our analysis had we compared between adjustable-rate and fixed-rate mortgage borrowers (Campbell and Cocco 2003).

\footnotetext{
${ }^{2}$ We note that less creditworthy or underwater borrowers had limited refinancing opportunities during our period of interest, and were thus particularly exposed to changes in mortgage rates through ARM rate resets.
} 
Applying a difference-in-differences methodology to our uniquely matched data, we explore the impact of lower monthly mortgage payments on a range of credit market outcomes. Our identification assumption, which we substantiate later, is that in the absence of the earlier reset, borrowers with 5/1 ARM contracts would display comparable patterns of behavior (up to a constant difference) relative to borrowers in the control group. Unsurprisingly, and consistent with prior work (e.g., Tracy and Wright (2012)), we find that households subject to lower mortgage rates have lower mortgage default rates.

Unlike previous studies, however, we examine the full credit portfolio, and find that households use the additional funds generated by lower mortgage payments to improve their position in the unsecured credit market, with significant declines in outstanding credit card debt, delinquent card balances, and credit card utilization rates after their mortgage rate resets. We estimate that outstanding credit card debt falls by $\$ 616$ on average during the first two years of lower rates, and that roughly $18 \%$ of the liquidity provided by lower mortgage payments goes toward "saving" in the form of paying down unsecured debts.

We also observe a relative increase in the auto debt balances of 5/1 ARM borrowers after the rate reset. Two years after the reset, auto balances of these borrowers increase on average by about $\$ 324$, which constitutes about $10 \%$ of the extra liquidity generated by rate reductions. This additional auto debt is driven by a sizable increase in new auto loan financing, reaching more than $10 \%$ in relative terms two years after the mortgage payment reduction. This finding supports the view that debt service costs inhibit durables purchases, as in Mian, Rao, and Sufi (2013), and in the literature on “consumption commitments” (see, e.g., Chetty and Szeidl 2007).

We identify important heterogeneity in the ability of monetary policy to stimulate households' consumption. New financing of durable consumption (auto purchases) by borrowers with lower wealth levels - as proxied by lower housing wealth—is significantly more responsive to mortgage payment reductions when compared with wealthier households. This finding is consistent with mainstream life-cycle household finance models (Zeldes 1989; Carroll and Kimball 1996; Carroll 1997) that predict a larger increase in consumption due to an income shock among borrowers with lower wealth levels. However, we also find that credit-constrained households - those with substantial credit card debt balances - display significantly smaller increases in auto debt financing, instead using more than $70 \%$ of the liquidity provided by lower 
mortgage payments to repay credit card debts during the first year after the rate reset. This debt deleveraging process significantly inhibits the transmission of monetary policy to consumer spending for these credit-constrained borrowers.

We also verify that our findings hold beyond agency mortgages. Applying our empirical strategy on another dataset that provides mortgage performance and credit records for less prevalent borrowers with non-agency loans, we broadly find similar qualitative effects. Any discrepancies between the two samples, as we discuss later, can best be explained by the characteristics of borrowers with non-agency loans in this sample relative to the overall population of U.S. mortgage borrowers. Overall, we document significant heterogeneity across borrowers in their response to mortgage payment reductions depending on their credit position and housing wealth.

In the second part of our analysis, we explore the impact of monetary policy on broader economic activity such as housing prices, aggregate durable consumption, and employment. In order to investigate such a connection, we exploit the significant regional heterogeneity in the share of mortgages that are of adjustable-rate type. The fraction of adjustable-rate mortgages in a region (zip code) is generally persistent over time and was determined prior to the large declines in interest rate indices that occurred during the recent crisis. Thus, we can trace the effects of these rate declines on economic outcomes using variation in this ex ante measure of regional exposure: Regions with a higher concentration of adjustable-rate mortgages were more likely to benefit from interest rate reductions than similar regions with a relatively lower concentration. Our analysis allows for constant differences (controlling for other observables) in the evolution in outcomes across zip codes with higher and lower shares of ARMs that are not due to interest rate declines.

We take a number of steps to address the natural concern that zip codes with a larger share of adjustable-rate mortgages could be different from those that have a lower share. First, we use propensity score matching methods to identify zip codes that have "common support" on observable characteristics. Second, in our analysis we control for a rich set of regional characteristics to account for any remaining observable differences across zip codes. Finally, our findings hold in both a difference-in-differences framework among matched zip codes, as well as an instrumental variables framework using all zip codes. 
Consistent with our earlier evidence, we show that regions with a higher concentration of adjustable-rate mortgage loans experienced a significant decline in prevailing mortgage interest rates following a drop in major interest rate indices. These more exposed regions also saw a relative decrease in mortgage default rates, lower rates of house price decline, increases in durable consumption (auto sales), and a relative improvement of employment growth in the nontradable sector. This evidence indicates that a reduction in mortgage rates during the most recent recession had an economically meaningful impact on foreclosures, delinquencies of non-targeted consumer debt, durable consumption, house prices, and employment (at least in the near term). These findings have direct implications for the literature that studies the pass-through of monetary policy and house price shocks to the real economy through mortgage contracts and household balance sheets (e.g., Hurst and Stafford 2004; Mian, Rao, and Sufi 2013; Mian and Sufi 2014; Scharfstein and Sunderam 2013; Chen et al 2013).

Our analysis contributes to the household finance literature and especially to studies that investigate the role of liquidity constraints and interest rates on consumer behavior (e.g., Gross and Souleles 2002; Agarwal, Chomsisengphet, Mahoney, and Stroebel, 2014). ${ }^{3}$ Our paper is also closely related to the literature on how households respond to income changes and government stimulus programs (e.g., Agarwal et al. 2007 and Parker et al. 2013). ${ }^{4}$ In the context of this literature, we provide an empirical assessment of the household response to a different form of stimulus: the prolonged reduction in mortgage rates through monetary policy during the economic crisis. This setting is unique because the size and persistence of the change in the cost of servicing mortgage debt reduces payments each month and by thousands of dollars over the term of the loan. Our estimates imply a fairly limited initial consumption response among creditconstrained households relative to the effects identified in the prior literature for other forms of stimulus (e.g., a one-time tax rebate). This limited response could reflect the different timing of "stimulus payments," as mortgage rate reductions mostly affect households' expected future disposable income. Finally, by exploiting regional variation in exposure to lower interest rates, we extend this literature and provide novel evidence on the broader consequences of monetary policy interventions.

\footnotetext{
${ }^{3}$ See Campbell (2006) and Tufano (2009) for recent surveys of this literature.

${ }^{4}$ Previous research has carefully examined the household responses to fiscal stimulus, in the form of tax refunds (Shapiro and Slemrod 1995), rebates (Shapiro and Slemrod 2003, Johnson et al. 2006, Agarwal et al. 2007, Shapiro and Slemrod 2009, Parker et al. 2013), or other transfer programs (e.g. Agarwal and Qian 2014; Hsieh 2003). See Jappelli and Pistaferri (2010) for a recent review of the extensive literature on the consumption response to income changes and Parker (2011) for the discussion of studies on the effects of fiscal policy in recessions.
} 
Our paper is also connected to studies that explore the effects of mortgage rate resets and renegotiations. ${ }^{5}$ This previous research has confirmed that homeowners who face smaller mortgage payments are less likely to default, which reduces the extent of foreclosures. In contrast, we take advantage of administrative agency mortgage performance data perfectly matched to a panel of consumer credit records to assess the impact of lower mortgage rates on a wide range of homeowners' consumer debt and credit outcomes. Our findings are also related to concurrent work by Di Maggio et al. (2014), who employ a similar identification strategy to analyze the effects of rate reductions in a sample of non-agency borrowers.

Finally, the literature surrounding the recent financial crisis, most notably the extensive work of Mian and Sufi (2009, 2014), has emphasized the importance of residential housing and household leverage in understanding the scope and depth of the recession, as well as the prior economic boom (Charles, Hurst, and Notowidigdo 2013). ${ }^{6}$ Agarwal et al. (2012) provide evidence that debt relief programs, when used with sufficient intensity, may meaningfully reduce foreclosures and delinquencies on non-targeted consumer debt, and positively impact house prices. Our paper explores another approach to encourage deleveraging by reducing households’ debt service obligations-namely, monetary policy through both conventional and unconventional (“quantitative easing”) channels. Our results, together with those of the previous work, support the view that policies designed to improve household balance sheets had a direct and sizeable positive impact on a broad range of economic outcomes during the recovery. ${ }^{7}$

\section{Data}

The main data used in this study comes from a large proprietary database of conventional mortgages securitized by a large secondary market participant. These mortgages are conforming loans made to borrowers with relatively high credit scores, low loan-to-value (LTV) ratios, and

\footnotetext{
${ }^{5}$ Piskorski et al. (2010) and Agarwal et al. (2011) examine the impact of securitization on mortgage foreclosure and renegotiation rates. Mayer et al. (2014) study the effects of modification programs on household behavior. Tracy and Wright (2012) use variation in mortgage rates implied by differences in contract types to estimate the impact of mortgage rate reductions on mortgage performance. Fuster and Willen (2013) use a similar econometric strategy as ours to study the impact of payment declines on mortgage outcomes. Haughwout et al. (2010), Agarwal et al. (2011, 2012), and Zhu (2012) explore the reduction in foreclosure rates due to modifications made by private lenders and through government modification and refinancing programs.

${ }^{6}$ See, among many others, Keys et al. (2010, 2012, 2013), Mian and Sufi (2009), Mian et al. (2011), and Favilukis, Ludvingson, and Van Nieuwerburgh (2013), Piskorski et al (2014).

${ }^{7}$ Our findings on the impact of monetary policy on consumer spending also relates to work on the real effects of government spending (Auerbach and Gorodnichenko 2011; Nakamura and Steinsson 2014).
} 
fully documented incomes and assets. Conforming mortgages meet the conforming loan limit, which has been $\$ 417,000$ since 2006 for a one-unit, single-family dwelling in a low-cost area. Our sample includes 5/1 and 7/1 ARMs originated between January 2003 and July 2007 that were used to finance single-family, one-unit properties. In order to evaluate the impact of differential timing of payment shocks to these two different contracts, loans in our sample must have made at least four years of payments and thus remain active at a loan age of 48 months. Our sample has 348,259 such loans, of which 244,765 are 5/1 ARMs and 103,494 are 7/1 ARMs.

From this mortgage data, we can identify all of the original loan information and subsequent payment activity in each month until the loan is voluntarily prepaid, foreclosed, or still active as of 2013:Q3. Information at origination includes borrower income, original FICO score, LTV ratio, loan balance, initial teaser rate, and the index and margins used for rate resetting. Payment activity in each month includes the actual mortgage rate based on index and margin, loan balance, and payment and delinquency (DLQ) status. We focus on 60+ days delinquent as our measure of delinquency status. In addition, using the data provider's proprietary zip-code-level home price indices and information on all liens on a given property, we are able to track the monthly mark-to-market combined LTV (CLTV) ratio for loans in our sample.

The data provider has merged this mortgage data with each borrower's consumer credit bureau records using Social Security number. The merge results in perfect match quality between these datasets for all borrowers. This combined data constitutes a considerable advantage over commercially available products, which instead commonly employ statistical match algorithms to conduct such a merge.

Our merged data allow us to observe the current credit history of mortgage holders in each month following loan origination. To capture the household balance sheet, we use information on the borrower's current FICO credit score, outstanding credit card balance, utilization rate of all credit cards, balance of all delinquent credit cards, auto debt balance, and outstanding student loan debt. The auto debt balance also allows us to identify new auto financing transactions, since such transactions are accompanied by a significant discontinuous increase in a borrower's outstanding auto debt. We also use recent credit inquiries as a proxy for new credit demand. Put together, this data provides a comprehensive look at each homeowner's overall credit portfolio. 
Finally, we note that on observable characteristics, our data is broadly representative of most U.S. mortgage borrowers. First, as Table 1 shows, our borrowers have mortgage balances and FICO credit scores that are close to the population averages (see Keys et al. 2010). Second, our data consist of agency-insured loans, a category of loans constituting the vast majority of residential mortgage loans issued in the United States. Third, while we focus on ARMs, we also verify that the distribution of observable risk characteristics in our sample is similar to the overall distribution of these characteristics among all (ARM and non-ARM) agency loans.

\section{Empirical Methodology and Descriptive Statistics}

Our difference-in-differences research design exploits variation in the timing of rate resets of adjustable rate mortgages with different initial fixed-rate periods. The design is predicated on the fact that borrowers with 5/1 ARMs - the treatment group -- have a five-year fixed rate period, while borrowers with 7/1 ARMs - the control group -- have a seven-year fixed period. After the fixed period concludes, these loans reset once a year thereafter based on the relevant index to which they are benchmarked. Thus in months 61 and 73 of the loan's life, the 5/1 ARMs reset to a new interest rate, while the 7/1 ARMs remain in their fixed-rate period. A similar identification strategy has been used to explore sensitivity of mortgage defaults to interest rates in Tracy and Wright (2012) and Fuster and Willen (2013). This previous research has quantified the extent to which homeowners who face smaller mortgage payments are less likely to default. We confirm that these patterns are also present in our nationally representative dataset. We then turn to the main focus of our analysis: the impact of lower mortgage rates on a broad range of spending and credit outcomes and the broader economic consequences of rate reductions.

More formally, to analyze the household-level response to rate resets, we run difference-indifferences regressions of the form:

$$
Y_{i t}=\alpha+\beta_{1} 1_{\text {Type }_{i}=5 / 1}+\beta_{2} 1_{\text {Loan Age }_{i t}>60}+\beta_{3} 1_{\text {Type }_{i}=5 / 1} 1_{\text {Loan Age }_{i t}>60}+\delta X_{i}+\varepsilon_{i t} .
$$

In the above specification, the dependent variable, $Y_{i t}$, is a credit-related outcome variable for borrower $i$ at time $t$. $\beta_{1}$ captures any baseline difference between credit outcomes of borrowers 
with 5/1 and 7/1 ARM loans, $\beta_{2}$ captures the vintage effect of having a mortgage which is outstanding for at least 60 months, and $\beta_{3}$ is our key coefficient of interest, indicating the difference-in-differences effect due to the mortgage rate adjustment. $X_{i}$ is a vector including borrower- and loan-level characteristics at origination, such as the initial rate, initial FICO score, and initial CLTV, as well as month of origination fixed effects and state fixed effects. The panel structure of our data allows us to exploit within-borrower variation before and after the rate resets. For robustness, we also interact the product dummy and loan age dummies with other controls to allow for more flexible specification.

A key identification assumption of our analysis is that credit outcomes of 5/1 and 7/1 ARM loans in our sample were generally similar across a range of characteristics at origination, and also experienced similar trends (up to a constant difference) prior to interest rate resets beginning in month 61. Table 1 provides support for this assumption in terms of borrower and contract characteristics, both at the beginning of our sample (in month 48 of their life, Panel A) and in month 60, the month immediately prior to the reset date (Panel B). At the time of loan origination, the average FICO scores of the borrowers of these two contract types are only four points apart, less than one-tenth of a standard deviation. The average mortgages also feature very similar interest rates, loan amounts, LTV ratios, and reset margins. In Panel B of Table 1, it is clear that by month 60, the fortunes of the two groups remain quite similar. The difference in FICO scores between borrowers with a 5/1 and 7/1 ARM is 11 points, or one-seventh of a standard deviation. In addition, 5/1 ARM borrowers have slightly more revolving debt and slightly higher utilization rates. Finally, Panel C of Table 1 indicates that both 5/1 and 7/1 borrowers have similar distributions of outstanding revolving debt balances, credit scores, and credit utilization rates prior to the first 5/1 ARM rate reset.

As we will show, between months 48 and 60 (the "pre-reset" period), 5/1 and 7/1 ARM borrowers exhibit similar trends in all of these variables. Observing similar trends prior to the first rate reset is comforting given that 5/1 ARM borrowers carry somewhat more credit card and auto debt and have slightly lower FICO scores, which suggest that the 5/1 ARM borrower group contains a slightly larger share of risky borrowers. We also look for anticipatory behavior of households prior to the rate change in month 61 and, as discussed below, do not find significant evidence of anticipatory effects. 
We next confirm that the rate reset has a substantial impact on the prevailing interest rate faced by borrowers and thus on their monthly payments during this period. Figure 1A shows the average current interest rate for each type of mortgage. In this figure and all subsequent figures using this microdata, vertical lines are added at month 60, the month preceding the first rate reset for the 5/1 ARM borrowers, and at month 72, which precedes the second interest rate reset. The corresponding difference-in-differences estimates, shown in the first column of Tables $2 \mathrm{~A}$ and 2B, indicate that that interest rates were 114 basis points lower on average one year after reset, and 175 basis points lower two years after reset, for 5/1 borrowers relative to 7/1 borrowers.

These rate resets translate into substantially lower monthly payments for 5/1 ARM borrowers, as shown in Figure 1B. Monthly payments drop dramatically in months 61 and 73, producing declines in monthly payments on average of \$125 during the first year and \$163 in the second year relative to their 7/1 counterparts (see the second column of Tables 2A and 2B), implying about 20\% reduction in monthly mortgage payments and a two-year cumulative savings of $\$ 3,456$ on average. This result represents the first stage of our analysis, as it is clear from Figures $1 \mathrm{~A}$ and $1 \mathrm{~B}$ that 5/1 ARM borrowers face very different monthly mortgage obligations after their reset date, despite being similar to 7/1 borrowers both at origination and at the time of the rate reset across a wide range of mortgage and credit characteristics.

\section{Micro Evidence}

\section{IV.A Impact of Mortgage Payment Reduction on Mortgage Default}

We first verify that, consistent with prior studies, lower mortgage payments induced by rate resets significantly reduce the likelihood of delinquency. Mean mortgage delinquency rates of 5/1 and 7/1 ARM borrowers follow similar patterns prior to the month 61 rate reset, but start to diverge with 5/1 ARM borrowers experiencing a relative decline in delinquencies when their payments are reduced (see Appendix A1). Our difference-in-difference estimates, shown in the third column of Tables $2 \mathrm{~A}$ and $2 \mathrm{~B}$, indicate that the likelihood of 60+-day delinquency falls by 0.5 percentage points on average after one year and 1.8 percentage points after two years. These estimates imply that a reduction of monthly mortgage payments by about $20 \%$ on average 
reduces the likelihood of mortgage delinquency after two years by about $40 \%$ relative to the mean delinquency rate among 5/1 ARM borrowers. ${ }^{8}$

\section{IV.B Impact of Mortgage Payment Reduction on Consumer Revolving Debt}

Our data, which merges administrative mortgage records with credit bureau records using Social Security numbers, allows us to explore the impact of lower monthly mortgage payments not only on mortgage performance but also on a range of other credit market outcomes. In this subsection we investigate the impact of rate reduction on consumer revolving debt, which mainly consists of credit card debt.

Figure 2A shows that the two groups had similar pre-reset trends in outstanding revolving debt, but that 5/1 ARM borrowers' outstanding debt falls steadily after the reset date. As the fourth column of Table 2 shows, one year after their rates reset substantially downward, 5/1 ARM borrowers had on average \$218 less in revolving credit card debt than 7/1 ARM borrowers who had not experienced a rate reset. Although the adjustments on this dimension of the credit portfolio are gradual, the gap in revolving debt widens to $\$ 616$ on average by two years after the rate reset. This estimate implies that the borrowers used on average about $18 \%$ of the additional $\$ 3,456$ received from rate reductions over two years to pay down their revolving debts.

We next analyze the dynamics of revolving debt balances in the periods before and after the reduction in mortgage payments (due to a rate reset). For this purpose we estimate a version of specification (1) with outstanding revolving debt balance as the dependent variable, but instead of a "post-reset" time dummy we include quarterly fixed effects for the loan's life and their interactions with the 5/1 mortgage type dummy. This allows us to estimate the cumulative differential change in the revolving debt balances of 5/1 ARM borrowers during the first three quarters preceding the interest rate reset as well as during each of the eight quarters following the rate reset (with the fourth quarter preceding the rate reset serving as the excluded category).

Figure 2B presents these estimates. The results show no significant evidence of differential changes in the outstanding revolving debt balances of 5/1 ARM and 7/1 ARM borrowers prior to

\footnotetext{
${ }^{8}$ We also verify (unreported) that these differences in default rates are related to differences in foreclosure rates.
} 
the rate reset. This confirms our inference from Figure 2A, which also shows no visible changes in the evolution of mean debt balances between these two groups of borrowers prior to the rate reset. Furthermore, consistent with our results from the fourth column of Table 2, Figure 2B shows a progressive relative decline in the revolving debt balances of 5/1 ARM borrowers after the reduction of their mortgage payments. We also estimate the version of specification (1) where we use quarterly changes in the revolving balance as the dependent variable and find similar results (see Section IV.E for more discussion).

These deleveraging effects can also be seen in the revolving credit utilization rate, which falls relatively by an estimated 1.6 percentage points for borrowers with 5/1 ARMs after the rate reset (see Appendix A2). We also find that mortgage borrowers who benefit from the rate reset are also less likely to carry any delinquent revolving credit debt balance after two years (see Appendix A1). These improvements in 5/1 ARM borrowers' position in the credit card market through deleveraging are highly statistically significant two years after the reset date.

IV.C Impact of Mortgage Payment Reduction on Durable Consumption (Auto) Financing and Other Credit Outcomes

We next turn our attention to the financing of car purchases by borrowers. As Figure 3A indicates, outstanding auto debt of the two groups of borrowers follows a similar pattern prior to the reset rate of 5/1 ARM contracts. Interestingly, we observe a steady relative increase in auto debt balance for 5/1 ARM borrowers after the rate reset. This effect is also visible in the fifth column of Table 2. In particular, during the two years after the reset, the auto balances of these borrowers increased on average by $\$ 324$ (the fifth column of Table 2B).

Figure 3B shows a progressive differential increase in auto debt balances of 5/1 ARM borrowers, reaching about $\$ 300$ in the eighth quarter after the reduction in mortgage payments. As in Figure 2B, the figure plots the quarterly interactions with a 5/1 mortgage-type dummy to capture the differential change in auto debt over the period. Consistent with our prior results, the figure also indicates no differential change in the average level of auto debt balances of 5/1 ARM and 7/1 ARM borrowers prior to the rate reset. 
We next investigate whether the relative increase in auto debt among borrowers experiencing the reduction in mortgage payments can be explained by an increase in new outstanding auto loans. Such new car loans can be identified in our data using the monthly evolution of auto debt balances. In particular, a substantial increase in outstanding auto debt in a given month is indicative of a new auto financing transaction. ${ }^{9}$ After identifying such instances in our data, we investigate the evolution of the probability of new auto financing among borrowers with 5/1 and 7/1 ARMs.

Figure 4A indicates a differential increase in the average probability of new auto financing of 5/1 ARM borrowers during the two years after the reset. Consistent with this pattern, the sixth column of Table 2 shows that 5/1 ARM borrowers experience a differential increase in new auto loan financing. This effect reaches 1.2 percentage points during the first two years of reduction in their mortgage payments (the sixth column of Table 2B).

Figure 4B presents the estimated differential change in the quarterly probability of new auto financing of 5/1 ARM borrowers before and after the rate reset. We find no evidence of differential changes in the probability of new auto financing in the quarters preceding the reduction of mortgage payments. Consistent with our results from Table 2, the estimates in Figure 4B indicate a progressive differential increase in the probability of new auto financing among borrowers experiencing a reduction in their mortgage payments. Two years after the reduction in mortgage payments, 5/1 ARM borrowers are significantly more likely to purchase a new car, with an estimated increase in the probability of new auto financing of $0.52 \%$, constituting an $11 \%$ relative increase in the probability of buying a new car.

The evidence above suggests that borrowers experiencing a reduction in mortgage payments increase their durable (auto) consumption. Using monthly auto debt payments as a proxy for monthly auto consumption, our results suggest that two years after a rate reset, the value of household durable consumption increased on average by $10 \%$ of the extra liquidity generated by the mortgage payment reductions over the two-year period. However, we interpret these results with caution as we do not observe other forms of auto financing (e.g., using cash).

\footnotetext{
${ }^{9}$ We identify new auto financing transactions if the borrower auto balance increases in a given month by at least $15 \%$ or by at least $\$ 5000$ for borrowers who did not have prior auto debt. Our results are robust to perturbations around these thresholds (e.g., considering $10 \%$ or $20 \%$ thresholds).
} 
We also observe that new credit inquires of 5/1 ARM borrowers initially rise in relative terms after the rate reset (the seventh column of Table 2A) and then subsequently fall (the seventh column of Table 2B), suggesting that the extra liquidity encouraged borrowers to finance new car purchases. Subsequently, however, these borrowers relied less heavily on other consumer debt, such as new credit card borrowing, for consumption smoothing and other purposes.

Furthermore, our analysis also establishes that reducing monthly mortgage payments enhances the overall credit standing of borrowers: 5/1 ARM mortgage-holders have significantly higher credit scores two years after the rate reset (see the eighth column of Table 2B and Appendix A2). In response to mortgage rate reductions, borrowers improve their overall credit position (and thus credit score) by reducing delinquency on both mortgage and credit card debt, reducing credit utilization rates, and increasing secured auto debt.

Finally, we also investigate the impact of rate reductions on the speed of repayment of household mortgage debt. In unreported results, we find no evidence of significant accelerated repayment of mortgage debt due to the downward rate reset, as the vast majority of borrowers continue to follow their scheduled mortgage payments. Likewise, we do not find a significant effect of mortgage payment reductions on the repayment of outstanding student debt.

\section{IV.D Response Heterogeneity}

The analysis thus far has focused on the average response of borrowers to mortgage payment reductions, finding that extra liquidity is used to pay down revolving debt and to increase durable consumption. However, less wealthy and liquidity constrained borrowers may be especially sensitive to changes in income or consumption commitments. In this section, we analyze borrowers' responses to mortgage payment reductions across available measures of liquidity constraints and wealth.

We use a borrower's credit card utilization rate as a direct measure of liquidity constraints, which is considered to be far superior to earlier survey-based proxies of perceived credit constraints (see, e.g., the discussion in Gross and Souleles 2002). For robustness, we also use FICO scores as a direct measure of creditworthiness, as borrowers with lower credit score levels generally 
experience more limited access to credit and face higher borrowing costs. We note that our empirical proxies of borrowers' creditworthiness and liquidity constraints are highly correlated with outstanding revolving debt. Borrowers with above median credit utilization (below median credit score) have on average about $\$ 15,842(\$ 12,476)$ more outstanding credit card debt compared with borrowers with below the median.

To proxy for the borrower's wealth level we use the combined loan-to-value (CLTV) ratio of outstanding mortgage debt. Borrowers with less housing equity can be thought of as being relatively less wealthy compared to similar borrowers with more housing equity. We note that borrowers with above median CLTV in our sample have very little equity -- less than $5 \%$ of current home value on average as of month 60 -- and many of these borrowers are underwater on their homes (i.e., have negative estimated housing equity). In contrast, borrowers with below median CLTV have a sizeable amount of positive equity left in their homes (more than 20\% of current home value on average).

Tables $3 \mathrm{~A}$ and $3 \mathrm{~B}$ investigate how the consumer response to mortgage payment reduction varies across the credit utilization rate and CLTV ratios. The regression specifications here interact the difference-in-differences terms (5/1 ARM, loan age $>60$, and the interaction of the two), as described in equation (1), with an indicator for whether these credit characteristics were above or below the median prior to the rate reset.

As we observe from the first column of Table 3, borrowers experienced fairly similar average reductions in monthly mortgage payments regardless of whether their credit utilization or CLTV ratios were above or below median. However, consistent with the basic economic intuition, these lower payments have much larger effect on reducing mortgage default risk among borrowers at higher risk of default (the second column of Table 3): those with above median CLTV ratios (less housing equity) and those with above median credit utilization rate (more liquidity constrained).

Interestingly, the third column of Table 3A suggest that borrowers with above-median credit utilization rates used on average about $40 \%-50 \%$ of additional liquidity in the first year of the rate reduction (depending on their CLTV ratios) to repay their revolving debt (about $\$ 591$ to 
$\$ 814$ of additional $\$ 1512$ to $\$ 1740$ received during the first year implied by $\$ 126$ to $\$ 140$ reduction in monthly mortgage payments). This “savings" increases to $\$ 1,116$ during the second year (the third column of Table 3B): about one-third of the overall extra liquidity of about $\$ 3,500$ obtained from the reduction in monthly mortgage payments over the two-year period.

These estimates imply that the "savings rate" from mortgage payments reductions of these credit-constrained households progressively declines over time as they repay their debts: While they allocate nearly $50 \%$ of the extra liquidity received during the first year to repay their revolving debts, repayment falls to $20 \%$ of the extra liquidity received during the second year. ${ }^{10}$ In contrast, we find no evidence that borrowers with below-median utilization rates "save" significant amounts of additional liquidity by repaying their debts, despite facing a similar reduction in mortgage payments. We find a similar pattern when we split the sample by FICO score, as homeowners with lower FICO scores paid down relatively more debt, especially revolving debt, during the two years after their mortgage rate reset (see Appendix A4).

Our results suggest that the desire to reduce debt may constrain the durable consumption response of these borrowers to rate reductions. As we observe from Table 3 and Appendix A3 and A4, borrowers with above-median credit utilization rates and borrowers with below-median FICO scores experience smaller increases in their auto debt levels following the reduction in their mortgage payments compared with more creditworthy borrowers.

On the other hand, low-wealth borrowers (those with higher CLTV ratios) with low credit utilization do not appear to use significant amounts of extra liquidity to repay their credit card debts. Interestingly, we find that these borrowers experience a much larger increase in auto debt as long as they are not heavy users of credit card debt: about $\$ 343$ to $\$ 440$ overall (the fourth column of Table 3B), which amounts to up to $12 \%$ of the value of the extra liquidity due to rate reductions. These low-wealth borrowers also experience a much greater relative increase in the absolute probability of a new auto finance transaction following the mortgage rate decrease, about 0.9 percentage points during the first year (the fifth column of Table 3A) and about 2.5 percentage points overall (the fifth column of Table 3B). As we observe from fourth and fifth columns of Table 3A, this impact on auto debt and probability of new auto financing during the

${ }^{10}$ Similar results hold in a specification without interaction terms for above-median CLTV (see Appendix A3). 
first year (the fourth and fifth columns of Table 3A) is much smaller if these borrowers have also substantial amount of revolving debt. ${ }^{11}$ This is consistent with our finding that these credit constrained borrowers allocate substantial amount of extra liquidity generated by rate reductions to repay their debts and improve their credit standing (especially during the first year) and hence may display a lower durable consumption response (at least initially). Consequently, we also observe the largest relative increase in credit scores among these borrowers two years after the reduction of their monthly payments (the sixth column of Table 3B).

These results suggest that more-constrained and more-indebted borrowers pay down more of their consumer debts than their less-constrained counterparts in response to a decrease in mortgage payments. To better gauge the magnitudes, we turn our attention to two subsamples of the relatively most constrained and least creditworthy borrowers, the top quartile of borrowers based on their credit utilization rates and the bottom quartile of borrowers based on their credit score. We estimate response of reduction in mortgage payments on debt deleveraging for these subsamples. As shown in Table 4, borrowers in the top quartile of credit utilization rates allocate about $70 \%$ of the extra liquidity generated by mortgage payment reductions in the first year toward repaying their credit card debt $(\$ 1,285$ of the $\$ 1,800$ generated by reductions in mortgage payments over the first year). We observe similar magnitudes among borrowers in the bottom quartile of credit scores. Consistent with our prior results, borrowers' propensity to use additional liquidity to repay their debts progressively declines over time: these constrained borrowers allocate about 30 to $40 \%$ of the overall extra liquidity received during two years of rate reductions towards revolving credit debt repayment. These results support the view that heavily indebted households initially prioritize relaxing their credit constraints and paying down their most expensive debts.

\section{IV.E Robustness and Extensions}

In this section we discuss a number of robustness checks we performed regarding our findings. For brevity reasons, several of these results are discussed but not reported. First, we verify that

\footnotetext{
${ }^{11}$ We also estimate a version of the specification from Table 3 where we also include interaction term of the high CLTV dummy with the above-median credit utilization dummy. This specification confirms that the response of auto financing debt of less wealthy borrowers to mortgage payments reductions is reduced if these borrowers also carry significant amount of credit card debt.
} 
our findings are not an artifact of differential prepayment and refinancing patterns across the two groups of borrowers, which could induce relative changes in the quality of borrowers around the rate resets. Here, we note that in the case of rate reductions such concerns may be less important, as lower mortgage rates deter prepayment. ${ }^{12}$ Moreover, the prepayment patterns of borrowers with these two types of loans generally follow similar patterns. As well, we confirm that our results hold in subsamples of loans that display very low refinancing probabilities around the reset rate. For example, we note that despite our focus on agency loans, our sample includes a significant number of mortgages with high current CLTV ratios (see Appendix A5). We find similar results when we restrict our attention to such borrowers with high CLTV ratios who face limited refinancing opportunities, as evidenced by their low prepayment speeds. ${ }^{13}$

In Appendix A6 we provide results from an even more rigorous approach to addressing concerns related to differential prepayment. We estimate a model of prepayment by month 48 (prior to our window of observation for the rest of our analysis) using loan and borrower characteristics at origination, such as income, FICO score, LTV, interest rate, and loan amount. We then predict a prepayment propensity based on the results of this regression (not shown). As a test of whether our results are affected by differential prepayment, we restrict our sample to only those loans present as of month 48 that have below-median prepayment propensity. As Appendix A6 shows, our results are consistent in terms of signs and magnitudes for all of our key results. ${ }^{14}$ Even in a sample of loans with low probability of prepayment, interest rate declines lead to reductions in mortgage delinquency, credit card debt, and credit utilization, and increases in auto debt and new auto financing.

Second, one could be concerned that some of our results are affected by the selection of borrowers (potentially on unobservables) into different product types (5/1 ARM versus 7/1 ARMs). As we discussed above, we do not find any evidence of differential patterns in evolution

\footnotetext{
${ }^{12}$ See Tracy and Wright (2012), who explain that in the case of mortgage payment reductions through rate resets, one would not expect to see a spike in prepayments in the treated group. They argue that this downward pressure on payments results in a relatively constant sample composition around reset dates.

${ }_{13}$ Borrowers with agency loans could also take advantage of the Home Affordable Refinancing Program, HARP, which started in 2009. However, initial restrictions on the extent of negative equity allowed would prevent many loans in our sample from refinancing. In addition, higher guarantee fees for less-creditworthy borrowers and other institutional factors may have significantly limited the reach of the program during the period of our study.

${ }^{14}$ We note that the estimated magnitude of the revolving debt repayment is smaller in this sample relative to the one based on overall data. This is due to a relatively smaller fraction of borrowers with significant amount of revolving debt in this sample compared to the overall data. Once we take this into account we do find very similar estimated changes in revolving debt repayment as in our overall sample.
} 
of credit outcomes between these two groups of borrowers prior to the reset rate, yielding support to our empirical design. In addition, we note that our results also hold when we match the loans in these groups more closely on characteristics observable at origination. Finally, 5/1 ARM resets occur in different time periods in our sample due to variation in origination dates. Exploiting reset timing variation only within the sample of 5/1 ARMs reveals similar effects of rate resets on outcomes.

Third, most of our specifications investigate the differential evolution in the cumulative level of a given credit outcome (e.g., revolving balance or auto debt). For robustness, we also estimated our specifications with the quarterly (or monthly) changes in the outcome variables as the dependent variable and find very similar results. ${ }^{15}$

Fourth, we verify that our findings also hold beyond agency mortgages. Using BlackBoxEquifax data that provides mortgage performance and credit records for borrowers with nonagency loans, and applying a similar empirical strategy to a sample of more than 50,000 nonagency adjustable-rate mortgages, we find broadly similar qualitative effects. However, the estimated magnitudes of some of the effects are different: For example, we find a larger increase in auto finance transactions due to rate reductions in the non-agency sample relative to the average effect in our main agency-based mortgage data (see Appendix A7). Our findings in the non-agency sample are consistent with contemporaneous work by Di Maggio et al. (2014) that provides a comprehensive analysis of the effects of rate reductions among non-agency borrowers and finds similar results. The differences in the estimated magnitudes of the effects among agency and non-agency borrowers can be explained by the differences in borrower characteristics, loan amounts, and contract terms across the two groups of borrowers. ${ }^{16}$

\footnotetext{
${ }^{15}$ See, for example, Appendix A7, which presents the estimated quarterly differential changes in the outstanding auto debt balance of 5/1 ARM borrowers relative to the revolving debt balance of 7/1 ARM borrowers in the three quarters preceding the first reset date of 5/1 ARMs and the eight quarters following the reset date.

${ }^{16}$ To apply a similar empirical strategy in the BlackBox-Equifax data, we need to confine our attention to a fairly small sample of mostly Alt-A non-agency loans (about 50,000 of loans compared to about 350,000 agency loans in our main sample). These loans are commonly given to borrowers with limited documentation, who buy more expensive homes relative to the population average, and who are much less likely to use them as their primary residence than the national average (see Keys et al. 2013 for more discussion of Alt-A borrowers). As these loans carry much larger balances than the ones in our data and often do not feature amortization of the principal amount after their first reset date, the effect of reset on the level of reduction in mortgage payments in the non-agency sample is more than four times as large as in our main agency sample - i.e., the monthly average reduction in mortgage payments is roughly $\$ 650$ among non-agency loans, compared to about $\$ 150$ among agency loans.
} 
Finally, our estimates report an average effect due to rate decreases across loans originated between 2003 and 2007 (with the first rate resets occurring for 5/1 ARMs between 2008 and 2012), although we control for quarterly origination cohort fixed effects in our specifications. We note, however, that our results are qualitatively unchanged when we perform our analysis in subsamples based on narrower ranges of origination dates.

\section{IV.F Implications for the Consumption Response to Mortgage Rate Reduction}

To directly investigate the connection between consumption and mortgage rate reductions, we would need individual consumption data linked to mortgage data, which we do not have access to. This problem is common to the household finance literature, which instead often infers the consumption response to various events from changes in consumer debt (see Gross and Souleles 2002). Such inferences, however, face a number of well-known challenges. For example, lack of data regarding checking, savings, stocks/401(k) accounts complicates inferences about a borrowers' saving rates. Keeping such caveats in mind, we will use our estimates regarding consumer debt patterns to infer some characteristics of the consumption response to mortgage rate reductions.

Our estimates point to a meaningful increase in durable consumption following a reduction in mortgage payments. This finding is consistent with studies that document an increase in durable consumption by households financed with collateralized lending following a positive income shock (see, for example, Aaronson, Agarwal, and French 2012 and Parker et al. 2013).

Our results also imply that less-creditworthy borrowers who carry significant revolving debt balances initially saved about $70 \%$ of additional liquidity from mortgage payment reductions in the form of repayment of credit card debt, thus allocating at most $30 \%$ of extra liquidity for spending purposes. Consistent with this observation, we also document weaker relative increases in financing of new durable consumption among these borrowers.

These findings may seem puzzling at first in light of the existing literature that generally documents a significantly higher propensity to spend from additional income among morecredit-constrained and less-wealthy households (e.g. Johnson et al. 2006; Agarwal et al. 2007; 
Parker et al. 2013). ${ }^{17}$ But these findings are not difficult to rationalize. First, we note that most of this literature focuses on the household response to a one-time increase in income, such as a tax rebate. In contrast, the additional liquidity in our setting results from a lower cost of servicing debt, received in monthly installments over the life of the loan-rather than in lump sum upfront. In this regard, life-cycle models of optimal household behavior indicate that the timing and persistence of income shocks can crucially affect the response in the cross-section of households. $^{18}$

Second, our results do not imply that the more-creditworthy households' propensity to spend is necessarily greater than less-creditworthy households'. Instead, our results suggest that lesscreditworthy households initially allocated at most $30 \%$ of the extra liquidity from rate reductions for spending purposes and appear to be less prone (at least initially) to use it for financing of new durable spending. As we do not observe the overall asset position of morecreditworthy households, these households may have displayed an even smaller overall consumption response.

Finally, we note that if we take higher CLTV ratios as a proxy for lower household wealth, we find that the durable consumption of borrowers with less wealth responds more strongly to reduction in mortgage payments compared with wealthier households. This effect is consistent with standard household life-cycle models (Zeldes, 1989; Carroll and Kimball 1996; Carroll 1997) that predict that households with lower wealth levels should exhibit larger marginal propensities to consume out of income shocks than households with more wealth. However, as discussed above, this response is significantly reduced if households carry substantial amounts of revolving debt, as these households initially allocate a significant part of their extra liquidity to repay their debts. Given that credit card debt often bears the highest interest rate that most households face, such behavior may not be surprising; this margin of adjustment could be the

\footnotetext{
${ }^{17}$ We note that in contrast to these papers, using survey techniques, Shapiro and Slemrod (2003) find that those households that are more likely to be constrained (i.e., have lower income) are those that are more likely mostly to save, rather than mostly to spend, the tax rebate.

${ }^{18}$ For example, in a setting with stochastic income, Zeldes (1989) shows that households facing more income risk may initially have a lower propensity to spend from an increase in current and future income compared with households with lower income risk. This dampened response occurs because while the spending of households subject to more risk optimally over-responds to changes in current income, it "under-responds" to changes in their expected future income relative to safer households. The latter effect can dominate the former one, which may result in the relatively lower consumption response to an increase in current and future income among less-creditworthy households, which face more income risk.
} 
most natural response for highly indebted consumers. ${ }^{19}$ Overall, this evidence points to a more nuanced interaction between measures of wealth and liquidity constraints in the consumer response to mortgage payment reductions.

We conclude this section by noting that models of household behavior predict differential responses to anticipated and unanticipated windfalls. In the case of an adjustable rate reset, the timing of the reset should be perfectly anticipated by homeowners, but the direction and magnitude of the reset requires information about how interest rates have evolved since the date of mortgage origination. The precise value of the index to which a mortgage is resetting is not available until just before the mortgage reset date. Moreover, work by Bucks and Pence (2008) has shown that ARM borrowers are particularly poorly informed about the features of their mortgage contract related to rate resets. Survey evidence suggests that $20 \%$ answer “don’t know" when asked about their original interest rate, and even larger fractions are unaware of the index their ARM is linked to, as well as per-period and lifetime interest rate caps and floors.

Based on our figures (and additional estimates not shown), our evidence suggests that there is no pre-treatment responsiveness to rate resets, with no differential improvements in any aspect of the credit portfolio occurring prior to month 61. Indeed, the improvements in 5/1 ARM homeowners' credit positions occur only gradually during the first two years after the first rate reset. This finding is consistent with research showing a delayed response of liquidityconstrained households to anticipated changes in their income or cost of debt. ${ }^{20}$ However, even among less-credit-constrained homeowners, we find no evidence of anticipatory behavior.

\section{Regional Evidence}

In this section we explore the impact of mortgage rate declines on regional outcome variables such as house prices, durable consumption (auto sales), and employment. The main challenge when attempting to infer such a connection is that interest rate movements affect borrowers in all regions. We address this challenge by exploiting regional heterogeneity in the share of

\footnotetext{
${ }^{19}$ For example, in 2013 the average credit card account carried an interest rate of about 13 percentage points (Bankrate.com), which is more than three times as large as newly reset mortgage interest rates in our sample. In addition, the U.S. tax system provides an incentive to prioritize repayment of credit card debt as interest payments on credit cards, unlike those on mortgage-related debt, are not tax deductible.

${ }^{20}$ For example, Stephens (2008) documents a significant consumption response to making final payments on a car loan, which suggests that some homeowners may be liquidity constrained and thus unable to respond in advance.
} 
adjustable-rate loans across regions. We first discuss our empirical design and then present our findings.

\section{V.A Empirical Design}

Because the fraction of adjustable-rate mortgages in a region is relatively persistent over time, and was determined prior to the period of declining rates, we can use variation in this ex-ante measure of program exposure to trace out the effects of interest rate declines on different economic outcomes. We compare outcomes in regions that had a relatively higher concentration of adjustable-rate loans - and therefore were also regions more likely to benefit from mortgage rate reductions - to otherwise similar regions with a relatively lower concentration of adjustablerate loans.

To account for general trends in economic outcomes over the recent period, we focus on the relative change in the evolution of economic outcomes during the period of rate declines in the zip codes with a high share of ARMs relative to the corresponding change in the zip codes with a lower share of ARMs. Our identification assumption is that in the absence of declining interest rates, and controlling for a host of observable risk characteristics, the economic outcomes in zip codes with a higher ARM share would have a similar evolution as those with a lower ARM share, up to a constant difference. This approach is similar to that used by Mian and Sufi (2010) in evaluating the effects of the "Cash for Clunkers" program, and by Agarwal et al. (2012), who evaluate the broader consequences of debt relief programs using regional variation in exposure to the Home Affordable Modification Program (HAMP). As in other regional studies that use a difference-in-differences strategy, we will not be able to attribute any economy-wide effects to declining interest rates.

It is worth emphasizing a key limitation of our empirical design—namely, that zip codes with a larger share of adjustable rate mortgages could be different on observable and unobservable dimensions from those with a lower share. For example, part of the observed differences in outcomes across zip codes over time may not only reflect greater exposure to interest rate declines but also the unobservable differences in the profiles of borrowers in these regions. 
We take a number of steps to address this concern. First, we focus only on zip codes that are relatively similar on key observables prior to the rate declines by matching the high- and lowexposure groups (e.g., zip codes with higher and lower share of ARMs, respectively) using a propensity score methodology and isolating the portion of the propensity score distribution with “common support.” This approach employs a set of matching covariates, including zip-codelevel averages of the FICO score of borrowers, interest rates, LTV, and delinquency rates at the beginning of our sample period. We obtain a sample of 1,000 zip codes (from an initial sample of about 10,000 zipcodes for which we have reliable data), each having at least 100 mortgage borrowers, equally split between high- and low-exposure groups after this matching exercise (see Figure 5 for the geographical distribution of the overall sample of zip codes). Second, in our analysis we control for many other characteristics of these zip codes to account for any remaining observable differences. Finally, we note that our analysis allows for differences in the evolution in outcomes across zip codes with higher and lower shares of ARMs that are not due to interest rate declines, as long as these differences are, controlling for other observables, roughly constant over time during our sample period.

Our empirical strategy to explore the impact of the rate declines on regional outcome variables relies on zip-code-level data. We focus on the sample period from mid-2006 through the end of 2012. As shown in Figure 7A, from mid-2006 through mid-2007 there were only minimal changes in the major interest rate indices. Afterward, however, these rate indices experienced a substantial decline, reaching record low levels around mid-2009 and remaining low thereafter. We expect borrowers in regions with a larger ARM share to be more exposed to declining interest rates through automatic rate resets.

To obtain information regarding mortgage characteristics in a zip code, we collect individual loan-level information from two databases. The first source is the BlackBox database, which provides a comprehensive, dynamic dataset with information for more than $90 \%$ of all privately (non-agency) securitized mortgages in the United States. The second source is the LPS database maintained by Black Knight Financial Services, which provides similar dynamic information on the vast majority of agency and bank-held loans. Combining these two datasets yields almost complete coverage of mortgage loans in the United States, allowing us to compute zip-code-level 
characteristics for variables such as average borrower FICO credit scores, zip code ARM share, and average mortgage interest rates.

We complement these datasets with the Equifax Credit Trends database, which contains zipcode-level consumer credit characteristics. In addition, we collect zip-code-level demographic information (e.g., median income, percentage of households with a college degree) from the Census Bureau's American Community Survey, house price indices from Zillow, and employment data from the Census Bureau’s ZIP Business Patterns database. ${ }^{21}$

We first verify that the matched zip codes in our sample are indeed similar on observables. Table $5 \mathrm{~A}$ compares the characteristics of zip codes in the period preceding the decline in interest rate indices (mid-2006 to mid-2007). To facilitate the comparison of zip code characteristics we split the matched sample into high exposure zip codes (those with above median share of ARMs) and low exposure zip codes (those with below median share of ARMs).

As we note from Table 5A, the observable characteristics are quite similar across the high- and low-exposure zip code groups. The high-exposure zip codes have very similar mean mortgage rates, credit scores, mortgage LTV ratios, unemployment rates, percentages of individuals with a college degree, and percentages of married households with children. It is worth noting that not only the means but the computed standard deviations of the two groups are quite similar on these dimensions. These patterns are also visible when we examine the evolution of FICO credit scores, LTV ratios, and interest rates in the high- and low-exposure regions in the pre-treatment period (see Figure 6) as well as the kernel densities of these variables (not shown). However, high-exposure zip codes have a larger mortgage delinquency rate (2.81\% versus $2.23 \%$ in low exposure zip codes). Importantly, as Figure 6A shows, the delinquency rate in high- and lowexposure zip codes followed similar trends in the period preceding the decline in interest rates.

Next, we verify that borrowers residing in zip codes with a higher ARM share are indeed more exposed to interest rate declines. As Table 5A indicates, despite the relative balance on observables, there remains significant variation in the fraction of loans that are ARMs in our

${ }^{21}$ We approximate the number of employees in each industry in a zip code by multiplying the number of establishments of a given employment size class by the median number of employees within the size class. 
matched sample. The low-exposure zip codes have a mean ARM-share percentage of 17.3\%, compared with a mean ARM share of 35.2\% in the high-exposure zip codes.

Figure 7B plots the average mortgage rates in the high- and low-exposure zip codes. We observe little difference in average mortgage interest rates prior to the major decline of interest rate indices, but a significant relative decline of average mortgage rates in high-exposure zip codes that after the decline of the overall level of interest rate indices. This relative decline of mortgage rates occurs progressively (with visible differences emerging after 2008:Q1) as ARMs reset to lower rate levels at various calendar dates, depending on their origination date and type. ${ }^{22}$ As the lower interest rates persisted, a larger fraction of ARMs reset to lower rates resulting in larger differences across high and low exposure zip codes. ${ }^{23}$

To verify this pattern more formally, Table 5B confirms a strong association between the zipcode-level ARM share and the extent of interest rate declines in a zip code between 2007:Q4 and 2012:Q4. The estimate in the first column of Table 5B implies that a 10 percentage point absolute increase in the zip-code ARM share is associated with a 20-basis-point reduction in average mortgage rates. The magnitude of this association is largely unaffected by the inclusion of a variety of control variables capturing the observable characteristics of zip codes. Furthermore, the size of this estimate is also reasonable, as the market interest rates to which ARMs are indexed declined by more than 400 basis points during the treatment period. However, as we discussed above, ARMs reset only periodically and caps and floors may limit the extent of rate fluctuations, so we would expect only a partial (and not instantaneous) passthrough of interest rate reductions to borrowers with ARMs.

\section{V.B Impact on Mortgage Delinquencies, Foreclosures, and House Prices}

We now turn to the impact of these rate declines on regional economic measures. First we verify that, consistent with our loan-level results, zip codes with a larger share of ARMs experience a relative decline in delinquencies and foreclosures. Using our matched sample, we estimate a

\footnotetext{
${ }^{22}$ ARMs usually carry fixed rates during the first few years of their maturity (e.g. initial 2, 3, 5 or 7 years)

${ }^{23}$ We verify that the relative decline in mortgage rates across zip codes is largely driven by the reset of ARMs that were originated prior to the decline of interest rate indices, rather than being driven by the origination of new loans after the decline of interest rate indices.
} 
regression with the change in the zip-code quarterly mortgage delinquency rate between the period of interest rate declines (2007:Q3 through 2012:Q4) and the period preceding the rate declines (2006:Q2 through 2007:Q2) as the dependent variable. Table 6A shows that, consistent with our loan-level analysis in Section IV, zip codes with a larger ARM share experienced a relative decline in mortgage delinquency growth rates during the period of declining interest rates. $^{24}$

An alternative way to illustrate these findings is to exploit only the differences between highand low-exposure regions. Figure 8A plots the mean quarterly mortgage delinquency growth rate in high- and low-exposure zip codes, including a vertical dashed line to mark the beginning of divergence of mortgage interest rates across zip codes following the decline in interest rate indices (2008:Q2). As we observe from Figure 8A, while the difference between high- and lowexposure zip codes remained stable in the period preceding the rate decline, we observe a relative reduction in the mortgage delinquency growth rate in high-exposure zip codes when mortgage interest rates declined after 2008:Q1.

Next, we examine the change in the house price growth in regions classified on the basis of their exposure to interest rate declines. Several recent papers argue that foreclosures create downward pressure on house prices (Campbell et al. 2011; Mian, Sufi, and Trebbi 2011). With the sizeable effect of interest rate declines on delinquency and foreclosures in high ARM share zip codes we found above, our empirical setting should allow us enough statistical power to detect house price effects as well.

Figure 8B shows that while the difference in quarterly house price growth between high and low exposure zip codes remained stable during the period of relatively constant rates, the gap between these groups grows during the period of rate declines. The estimates in Table 6B confirm that zip codes with a larger share of ARMs experienced a relative increase in house price growth. A 10 percentage point increase in the ARM share, which is associated with about a 20basis-point average reduction in zip-code mortgage rates (Table 5B), is associated with about a

\footnotetext{
${ }^{24}$ In unreported results, we also find similar results when we consider the foreclosure rate: zip codes with a larger share of ARMs saw a relative decline in the foreclosure growth rate during the period of interest rate declines.
} 
0.25 percentage point increase in quarterly house price growth (the third column of Table 6B). ${ }^{25}$ In sum, zip codes with significant exposure to the decline in interest rate indices saw a meaningful relative increase in house price growth.

\section{V.C Impact on Durable Consumption and Employment}

Finally, we investigate the association between mortgage rate declines, durable consumption and employment. Unlike in the credit record, where we could only infer auto purchases from significant increases in auto debt, we can measure auto purchases directly at the zip code level. ${ }^{26}$ Figure 6C shows the time-series evolution of the annual auto sales growth rate in high and low exposure zip codes. As we observe, zip codes with more ARMs experienced a relative increase in new auto sales growth rate compared to zip codes with fewer ARMs after the decline in interest rates. The estimates in Table 6C (Column 3) confirm this pattern, with a 10 percentage point increase in the ARM share is associated with a 0.37 percentage point increase in quarterly auto sales growth. This result is consistent with our micro-level findings, and confirms on a regional level that monetary policy had a significant impact on durable purchases.

Next we turn our attention to employment. Figure 8C plots the time-series evolution of the annual growth in employment at the zip code level in high and low exposure zip codes, while Columns (1)-(3) of Table 7 provide the regression results. The figure shows that employment growth rates in high and low exposure zip codes followed similar patterns prior to the relative decline in mortgage rates, with no statistically significant difference once we account for the differences in zip code characteristics as indicated by the third column of Table 7 . However, during the period of declining mortgage rates (2009-2012), we document a relative increase in the employment growth rate in high-exposure regions: a 10 percentage point increase of the ARM share is associated with about $0.89 \%$ increase in the annual employment growth rate (third column of Table 7).

\footnotetext{
${ }^{25}$ It is, of course, possible that part of this house price effect reflects a change in the composition of transacted properties due to the relatively lower intensity of foreclosure sales in the high-exposure zip codes. To assess the robustness of our results to this concern, in results not shown we repeated this exercise using the CoreLogic house price index, which excludes distressed transactions. Our inferences remain unchanged.

${ }^{26}$ The data on auto purchases is from R. L. Polk \& Company (see Mian, Rao, and Sufi 2013).
} 
We next investigate which sectors can account for the relatively higher growth rate of employment in high-exposure zip codes. The fourth column of Table 7 repeats the above analysis for employment growth in restaurant and grocery stores, a proxy for the local nontradable sector. The fifth column shows the corresponding results for employment growth in the sector consisting of industries classified as producing tradable goods and services. ${ }^{27}$ As we observe, high-exposure zip codes experienced a significant relative increase in employment growth in the non-tradable sector during the period of rate declines: a 10 percentage point increase in the ARM share being associated with about 0.64 percentage point increase in the annual employment growth rate in restaurant and grocery sector (the fourth column of Table 7). In contrast, we observe no relative change in the growth of the tradable sector between high- and low-exposure zip codes (the estimate in the fifth column of Table 7 implies that a 10 percentage point increase in the ARM share is associated with statistically insignificant 0.018 percentage point relative decline in the annual employment growth rate in tradable sector during the period of rate reductions). This finding is reassuring, as we should not expect to find a significant association between relative employment growth in the tradable sector, which reflects broader economic conditions, and the local (zip-code-level) differential improvement in household balance sheets.

Overall, our findings at the regional level corroborate those of Mian and Sufi (2014), who present evidence that adverse shocks to household balance sheets can account for a large fraction of the decline in U.S. employment from 2007 to 2009. Consistent with this view, our results suggest that a relative improvement in household balance sheets due to mortgage rate declines had a significant positive impact on local (non-tradable) employment growth, at least in the near term.

\section{V.D Instrumental Variable Analysis}

We verify the robustness of our regional analysis in the full sample of zip codes -- not just the matched subset of zip codes -- by directly instrumenting for the intensity of mortgage rate

27 To classify industries as either non-tradable or tradable industries, we closely follow Mian and Sufi (2014). Specifically, retail- and restaurant-related industries are taken as non-tradable, while industries that appear in the global trade category are considered tradable. 
reductions with our measure of ex ante exposure to rate reductions (ARM share of loans in that region). As is shown in Appendix A8, the first stage is strong, economically significant, and in the expected direction: a 10 percentage point increase in the zip-code ARM share is associated with about a 20-basis-point reduction in average mortgage rates (Panel $\mathrm{A}$ in Appendix A8). In the second stage, we find similar patterns as our earlier results. In particular, we find that a one percentage point absolute decrease in the predicted zip code average mortgage interest rate (about a 15\% relative reduction in average mortgage interest payments) is associated with an 18 percentage point reduction in the quarterly mortgage delinquency growth rate (the third column of Panel B in Appendix A8), a 0.79 percentage point increase in the house price growth rate (the sixth column of Panel B), and a 1.26 percentage point increase in the growth rate of new auto sales (the ninth column of Panel B). In sum, our findings hold in both a difference-in-differences framework among matched zip codes, as well as an instrumental variables framework using all zip codes.

\section{Discussion and Concluding Remarks}

We find that the large interest rate declines due to monetary policy changes by the Federal Reserve had a direct and substantial impact on household balance sheets and local economies where consumers and regions were relatively more exposed to rate declines. Consumers who experienced reductions in their debt service costs due to rate declines reduced their credit card debt, purchased new automobiles, and were less likely to be delinquent on both secured and unsecured debt. These choices had significant impacts on foreclosures, house prices, and employment in regions that were more exposed to interest rate declines.

Our results support the view that policies aimed at reducing mortgage rates can have a meaningful impact on macroeconomic conditions by improving household balance sheets. This evidence is consistent with Agarwal et al. (2012), who find that mortgage modification programs, when used with sufficient intensity, may improve a range of economic outcomes, and more broadly with Mian and Sufi (2009, 2014) and Mian et al. (2013) who emphasize the importance of household debt in understanding the scope and depth of the recession. However, Agarwal et al. (2012) also show that modification programs face substantial barriers to implementation related to the industrial organization of the mortgage finance industry. In that 
sense, by reducing the mortgage rates of ARM borrowers, low interest rate polices may achieve similar effects to mortgage modification programs for these borrowers more quickly (at least in the near term).

By automatically reducing mortgage rates when market rates are low, ARMs can also help alleviate other frictions in the mortgage refinancing market. First, rate resets allow refinancing of borrowers regardless of the extent of their housing equity or creditworthiness. Second, they can help reduce frictions due to the limited competition in the loan refinancing market (see Scharfstein and Sunderam 2013). Third, by automatically reducing mortgage rates, ARMs may help alleviate the barriers to loan renegotiation due to securitization (Piskorski et al. 2010; Agarwal et al. 2011) and lender concerns regarding borrowers' strategic behavior (Mayer et al. 2014). Fourth, existing research provides evidence of significant inertia and inattention in mortgage refinancing decisions by borrowers (e.g., Keys, Pope, and Pope 2014; Andersen et al. 2014). As ARM contracts do not require the active participation of borrowers in the process of rate reduction, they can help alleviate the adverse effects of such factors for mortgage refinancing. Finally, temporary payment reductions induced by ARMs may achieve similar outcomes as permanent reductions of mortgage principal in a potentially more cost effective way (Eberly and Krishnamurthy 2014). ${ }^{28}$

Our results also highlight the potential limits of monetary policy to quickly stimulate household consumption through lower mortgage rates. In particular, our evidence suggests that creditconstrained households carrying significant credit card debt balances allocate a substantial part of the liquidity provided by lower mortgage payments to paying down their unsecured debt. Consequently, this debt deleveraging process can significantly dampen the initial consumption response of these borrowers. Our findings also indicate that a sizable part of the initial stimulus provided by lower mortgage rates may have been transferred to the banking sector through the repayment of consumer debt. ${ }^{29}$ One implication of these findings is that in order to stimulate household consumption, government policies may also consider directly targeting the cost of servicing credit card and other higher-interest debts.

\footnotetext{
${ }^{28}$ See also Piskorski and Tchistyi (2010) who highlight benefits of ARMs in an optimal dynamic contracting framework.

${ }^{29}$ In this regard, our results are similar to those in Hsu, Matsa, and Melzer (2014), who find that expansion of unemployment insurance also increased loan repayment. Thus, countercyclical programs of both fiscal and monetary types have been shown to produce indirect benefits to the banking sector.
} 
Finally, it is important to reiterate a few limitations of our results. First, we focus on the effect of low interest rate policies on household balance sheets that operate through the reduction of mortgage rates on outstanding loans, leaving other channels aside (e.g., through a decline in credit card payments, easier refinancing abilities, etc.). Second, due to the nature of our empirical design, we are not able to comment on any economy-wide effects introduced by interest rate declines. Finally, we cannot comment on the broader welfare implications of low interest rate policies. Doing so would require a proper assessment of the overall value of such polices, including their potential long-term costs and distributional consequences.

\section{References}

Aaronson, Daniel, Sumit Agarwal, and Eric French, 2012, The Spending and Debt Response to Minimum Wage Hikes, American Economic Review 102, 3111-39.

Agarwal, Sumit, Nicholas S Souleles, Chunlin Liu, 2007, The Reaction of Consumer Spending and Debt to Tax Rebates-Evidence from Consumer Credit Data, Journal of Political Economy 115, 9861019.

Agarwal, Sumit, Gene Amromin, Itzhak Ben-David, Souphala Chomsisengphet, Douglas D. Evanoff, 2011, The Role of Securitization in Mortgage Renegotiation, Journal of Financial Economics, 102(3), 559-578.

Agarwal, Sumit, Gene Amromin, Itzhak Ben-David, Souphala Chomsisengphet, and Douglas D. Evanoff, 2011, Market-Based Loss Mitigation Practices for Troubled Mortgages Following the Financial Crisis, Federal Reserve Bank of Chicago Working Paper No. 2011-03.

Agarwal, Sumit, Gene Amromin, Itzhak Ben-David, Souphala Chomsisengphet, Tomasz Piskorski, and Amit Seru, 2012, Policy Intervention in Debt Renegotiation: Evidence from Home Affordable Modification Program, NBER Working Paper 18311.

Agarwal, Sumit, and Wenlan Qian, 2014, Consumption and Debt Response to Unanticipated Income Shocks: Evidence from a Natural Experiment in Singapore, forthcoming in the American Economic Review.

Agarwal, Sumit, Souphala Chomsisengphet, Neale Mahoney, Johannes Stroebel, 2014, Regulating Consumer Financial Products: Evidence from Credit Cards, forthcoming in the Quarterly Journal of Economics.

Andersen, Steffen, John Y. Campbell, Kasper Meisner Nielsen, and Tarun Ramadorai, 2014, Inattention and Inertia in Household Finance: Evidence from the Danish Mortgage Market, working paper. 
Auerbach, Alan, and Yuriy Gorodnichenko, 2011, Fiscal Multipliers in Recession and Expansion, in Fiscal Policy after the Financial Crisis, University of Chicago Press.

Bernanke, Ben S., and Mark Gertler, 1995, Inside the Black Box: The Credit Channel of Monetary Policy Transmission." Journal of Economic Perspectives 9: 27-48.

Bucks, Brian, and Karen Pence, 2008, Do Borrowers Know Their Mortgage Terms? Journal of Urban Economics.

Campbell, John Y., 2006, Household Finance, Journal of Finance 61, 1553-1604.

Campbell, John Y., and Joao F. Cocco, 2003, Household Risk Management and Optimal Mortgage Choice, Quarterly Journal of Economics 118, 1449-1494.

Campbell, John Y., Stefano Giglio, and Parag Pathak, 2011, Forced Sales and House Prices, American Economic Review 101, 2108-2131.

Carroll, Chris D., 1997, Buffer-Stock Saving and the Life Cycle/Permanent Income Hypothesis, Quarterly Journal of Economics 112, 1-54.

Carroll, Chris. D, and Miles S. Kimball, 1996, On the Concavity of the Consumption Function, Econometrica 64, 981-992.

Charles Kevin K., Erik Hurst, Matthew J. Notowidigdo, 2013, Manufacturing Decline, Housing Booms, and Non-Employment, NBER Working Paper No. 18949.

Chen, Hui, Michael Michaux, and Nick Roussanov, 2013, Houses as ATMs? Mortgage Refinancing and Macroeconomic Uncertainty, NBER Working Paper No. 19421.

Chetty, Raj, and Adam Szeidl, 2007, Consumption Commitments and Risk Preferences, Quarterly Journal of Economics 122, 831-877.

Di Maggio, Marco, Amir Kermani, and Rodney Ramcharan, 2014, Monetary Pass-Through: Household Consumption and Voluntary Deleveraging, Working Paper.

Eberly, Janice, and Arvind Krishnamurthy, 2014, Efficient Credit Polices in a Housing Crisis, Fall 2014 Brookings Panel on Economic Activity.

Favilukis, Jack, Sydney Ludvingson, and Stijn Van Nieuwerburgh, 2013, The Macroeconomic Effects of Housing Wealth, Housing Finance, and Limited Risk Sharing in General Equilibrium, working paper.

Fuster, Andreas, and Paul S. Willen, 2013, Payment Size, Negative Equity, and Mortgage Default, NBER Working Paper No. 19345.

Gross, David B., and Nicholas S. Souleles, 2002. Do Liquidity Constraints and Interest Rates Matter for Consumer Behavior? Evidence from Credit Card Data, Quarterly Journal of Economics 117, 149185. 
Haughwout, Andrew, Ebiere Okah, and Joseph Tracy, 2010, Second Chances: Subprime Mortgage Modification and Re-Default, forthcoming in the Journal of Money, Credit, and Banking.

Hurst, Erik and Frank Stafford, 2004, Home is Where the Equity is: Mortgage Refinancing and Household Consumption, Journal of Money Credit and Banking 36, 985-1014

Hsieh, Chiang-Tai, 2003, Do Consumers React to Anticipated Income Shocks? Evidence from the Alaska Permanent Fund, American Economic Review 93, 397-405.

Hsu, Joanne W., David A. Matsa, and Brian T. Melzer, 2014, Positive Externalities of Social Insurance: Unemployment Insurance and Consumer Credit, NBER Working Paper 20353.

Jappelli, Tullio, and Luigi Pistaferri, 2010, The Consumption Response to Income Changes, Annual Review of Economics, 2: 479-506.

Johnson D.S., Parker J.A., Souleles N.S., 2006. Household Expenditure and the Income Tax Rebates of 2001. American Economic Review 96: 1589-1610.

Parker, Jonathan A., Nicholas S. Souleles, David S. Johnson, and Robert McClelland. 2013, Consumer Spending and the Economic Stimulus Payments of 2008, American Economic Review 103, 2530-2553.

Keys, Benjamin J., Tanmoy Mukherjee, Amit Seru, and Vikrant Vig, 2010, Did Securitization Lead to Lax Screening: Evidence from Subprime Loans, Quarterly Journal of Economics 125, 307-362.

Keys, Benjamin J., Amit Seru, and Vikrant Vig, 2012, Lender Screening and Role of Securitization: Evidence from Prime and Subprime Mortgage Markets, Review of Financial Studies, forthcoming.

Keys, Benjamin J., Tomasz Piskorski, Amit Seru, and Vikrant Vig, 2013, "Mortgage Financing in the Housing Boom and Bust”, in the Housing and Financial Crisis, Edward Glaeser and Todd Sinai, editors, NBER and University of Chicago Press.

Keys, Benjamin J., Devin G. Pope, and Jaren C. Pope, 2014, Failure to Refinance, NBER Working Paper No. 20401.

Mayer, Christopher, Edward Morrison, Tomasz Piskorski, and Arpit Gupta, 2014, Mortgage Modification and Strategic Behavior: Evidence from a Legal Settlement with Countrywide, American Economic Review 104, 2830-285.

Mian, Atif, and Amir Sufi, 2009, The Consequences of Mortgage Credit Expansion: Evidence from the U.S. Mortgage Default Crisis, Quarterly Journal of Economics 124, 1449-1496.

Mian, Atif, and Amir Sufi, 2010, The Effects of Fiscal Stimulus: Evidence from the 2009 'Cash for Clunkers' Program, Quarterly Journal of Economics.

Mian, Atif, Amir Sufi, and Francesco Trebbi, 2011, Foreclosures, House Prices, and the Real Economy, forthcoming in the Journal of Finance.

Mian, Atif, Kamalesh Rao, and Amir Sufi, 2013, Household Balance Sheets, Consumption, and the Economic Slump, forthcoming in the Quarterly Journal of Economics. 
Mian, Atif, and Amir Sufi, 2014, What Explains the 2007-2009 Drop in Employment?, forthcoming in Econometrica

Nakamura, Emi, and Jon Steinsson, 2014, Fiscal Stimulus in a Monetary Union: Evidence from US Regions, American Economic Review 104, 753-792.

Parker, Jonathan, 2011, On Measuring the Effects of Fiscal Policy in Recessions, Journal of Economic Literature, 49, 703-718.

Piskorski, Tomasz, Amit Seru, and Vikrant Vig, 2010, Securitization and Distressed Loan Renegotiation: Evidence from the Subprime Mortgage Crisis, Journal of Financial Economics 97, 369-397.

Piskorski, Tomasz, and Alexei Tchistyi, 2010, Optimal Mortgage Design, Review of Financial Studies 23, 3098-3140.

Piskorski, Tomasz, Amit Seru, and James Witkin, 2014, Asset Quality Misrepresentation by Financial Intermediaries: Evidence from RMBS Market, forthcoming in the Journal of Finance.

Scharfstein, David, and Adi Sunderam, 2013, Concentration in Mortgage Lending, Refinancing Activity, and Mortgage Rates, NBER working paper 19156.

Shapiro, Matthew D., and Joel Slemrod, 1995, Consumer Response to the Timing of Income: Evidence from a Change in Tax Withholding, American Economic Review, 85: 274-283.

Shapiro, Matthew D., and Joel Slemrod, 2003, Consumer Response to Tax Rebates, American Economic Review, 93: 381-396.

Shapiro, Matthew D., and Joel Slemrod, 2009, Did the 2008 Tax Rebates Stimulate Spending?, American Economic Review Papers and Proceedings, 99: 374-379.

Stephens, Mel, 2008, The Consumption Response to Predictable Changes in Discretionary Income: Evidence from the Repayment of Vehicle Loans, The Review of Economics and Statistics 90, 241252.

Stroebel, Johannes, and John B. Taylor, 2012, Estimated Impact of the Federal Reserve's MortgageBacked Securities Purchase Program, International Journal of Central Banking, 8(2).

Tracy, Joseph, and Joshua Wright, 2012, Payment Changes and Default Risk: The Impact of Refinancing on Expected Credit Losses, Federal Reserve Bank of New York Staff Report No. 562.

Tufano, Peter, 2009, Consumer Finance, Annual Review of Financial Economics 1, 227-247.

Zeldes, Stephen P., 1989, Optimal Consumption with Stochastic Income: Deviations from Certainty Equivalence, Quarterly Journal of Economics 107, 275-298.

Zhu, Jun, 2012, Refinance and Mortgage Default: An Empirical Analysis of the HARP's Impact on Default Rates, Freddie Mac Working Paper. 
Table 1: Summary Statistics

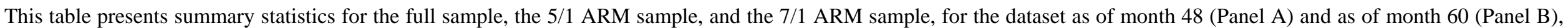

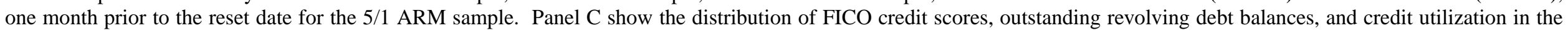
5/1 ARM sample, and the 7/1 ARM sample for loans in their 60th month of age. Source: Authors' calculations using data from the large secondary market participant.

Panel A: Summary Statistics for Loans in Month 48

\begin{tabular}{lcccccc}
\hline \hline & \multicolumn{2}{c}{ Full Sample } & \multicolumn{2}{c}{ 5/1 ARMs } & \multicolumn{2}{c}{ 7/1 ARMs } \\
& Mean & S.D. & Mean & S.D. & Mean & S.D. \\
\hline Original Rate & 5.05 & 0.71 & 5.02 & 0.75 & 5.12 & 0.60 \\
Current Rate & 5.05 & 0.71 & 5.02 & 0.75 & 5.12 & 0.60 \\
Margin & 2.48 & 0.31 & 2.48 & 0.32 & 2.48 & 0.28 \\
Current Mortgage Payment & 1,013 & 441.89 & 1,012 & 444.79 & 1,014 & 434.95 \\
Number of Student Loans & 0.42 & 0.80 & 0.41 & 0.80 & 0.42 & 0.81 \\
Number of Recent Credit Inquiries & 1.86 & 2.05 & 2.00 & 2.08 & 1.76 & 1.98 \\
Revolving Debt & 12,426 & 19,149 & 12,642 & 19,427 & 11,901 & 18,483 \\
Delinquent Revolving Debt & 0.036 & 0.21 & 0.04 & 0.22 & 0.03 & 0.20 \\
Revolving Utilization & 24.26 & 26.25 & 24.99 & 26.74 & 22.55 & 24.97 \\
Auto Debt & 9,147 & 14,262 & 9,223 & 14,361 & 8,995 & 14,026 \\
Origination FICO & 725.76 & 53.86 & 724.42 & 53.96 & 728.95 & 53.51 \\
Current FICO & 727.07 & 78.09 & 724.40 & 79.52 & 733.38 & 74.21 \\
Origination Combined LTV & 74.00 & 17.75 & 74.15 & 17.93 & 73.64 & 17.31 \\
Mortgage Delinquency Rate & 0.02 & 0.18 & 0.026 & 0.025 & 0.015 & 0.15 \\
\hline Number of Loans & 348,259 & & 244,765 & & 103,494 &
\end{tabular}


Table 1 [continued]

Panel B: Summary Statistics for Loans in Month 60 (one month before 5/1 ARMs reset)

\begin{tabular}{|c|c|c|c|c|c|c|}
\hline & \multicolumn{2}{|c|}{ Full Sample } & \multicolumn{2}{|c|}{ 5/1 ARMs } & \multicolumn{2}{|c|}{ 7/1 ARMs } \\
\hline & Mean & S.D. & Mean & S.D. & Mean & S.D. \\
\hline Original Rate & 5.04 & 0.72 & 5.02 & 0.76 & 5.10 & 0.60 \\
\hline Current Rate & 5.04 & 0.72 & 5.02 & 0.76 & 5.10 & 0.60 \\
\hline Margin & 2.48 & 0.31 & 2.48 & 0.32 & 2.49 & 0.28 \\
\hline Current Mortgage Payment & 1,010 & 443 & 1,010 & 447 & 1,008 & 434 \\
\hline Number of Student Loans & 0.41 & 0.81 & 0.41 & 0.81 & 0.42 & 0.82 \\
\hline Number of Recent Credit Inquiries & 1.85 & 2.02 & 1.90 & 2.06 & 1.74 & 1.92 \\
\hline Revolving Debt & 12,846 & 18,430 & 13,040 & 18,819 & 12,413 & 17,536 \\
\hline Delinquent Revolving Debt & 0.05 & 0.18 & 0.05 & 0.18 & 0.04 & 0.16 \\
\hline Revolving Utilization & 25.40 & 78.13 & 26.46 & 92.75 & 23.09 & 25.17 \\
\hline Auto Debt & 8,463 & 21,144 & 8,465 & 21,922 & 8,459 & 19,361 \\
\hline Origination FICO & 725.00 & 54.39 & 723.28 & 54.54 & 728.78 & 53.85 \\
\hline Current FICO & 725.25 & 77.24 & 721.74 & 78.89 & 732.91 & 72.91 \\
\hline Origination Combined LTV & 73.89 & 17.81 & 74.13 & 17.97 & 73.34 & 17.45 \\
\hline Mortgage Delinquency Rate & 0.04 & 0.20 & 0.04 & 0.00 & 0.03 & 0.17 \\
\hline
\end{tabular}

Panel C: Distribution of Credit Scores and Revolving Debt Balances for Loans in Month 60 (one month before 5/1 ARMs reset)

\begin{tabular}{lcccc}
\hline \hline & $\mathrm{p} 25$ & $\mathrm{p} 50$ & $\mathrm{p} 75$ & $\mathrm{p} 90$ \\
\hline & \multicolumn{5}{c}{ Overall Sample } \\
\hline Current FICO & 688.75 & 747.00 & 785.67 & 801.00 \\
Revolving Debt Balance & 2,273 & 5,956 & 16,200 & 33,488 \\
Utilization Rate & 5.43 & 14.47 & 37.77 & 67.40 \\
\hline & \multicolumn{4}{c}{$5 / 1$ ARMs } \\
\hline Current FICO & 683.75 & 743.00 & 784.00 & 800.50 \\
Revolving Debt Balance & 2,303 & 6,145 & 16,665 & 34,102 \\
Utilization Rate & 5.60 & 15.33 & 39.87 & 69.55 \\
\hline & \multicolumn{5}{c}{$7 / 1$ ARMs } \\
\hline Current FICO & 698.80 & 755.20 & 788.50 & 802.00 \\
Revolving Debt Balance & 2,215 & 5,589 & 15,190 & 32,031 \\
Utilization Rate & 5.11 & 12.84 & 33.27 & 61.96 \\
\hline \hline
\end{tabular}




\section{Table 2: Baseline Difference-in-Differences Regressions for the Treatment Effect of Mortgage Payment Reduction}

This table presents difference-in-difference OLS specifications to examine the differential outcomes for 5/1 ARM contracts relative to 7/1 ARM contracts after the 5/1 contracts' first reset date. Panel A presents the estimated relative change in outcomes during the first year after the reset, while Panel B presents similar results for the period of two years after the first reset (but before the 7/1 rate reset). The coefficient of interest, Treatment, is the estimated change in the difference between outcomes of 5/1 ARM and 7/1 ARM contract types during the period after the reset date. Thus, this coefficient captures the differential effect of the mortgage rate decline (due to a reset) on outcomes of mortgages subject to a reset (5/1 ARM contracts) relative to outcomes of mortgages that did not experience a change in interest rate (7/1 ARM contracts). The specifications include a rich set of observable characteristics as control variables including loan age and mortgage product dummies, rate at origination, FICO credit score, CLTV, quarter-year origination fixed effects and state fixed effects. Standard errors clustered by quarter of origination are in parentheses.

Panel A: One Year after Mortgage Payment Reduction

\begin{tabular}{|c|c|c|c|c|c|c|c|c|}
\hline & $\begin{array}{c}\text { Monthly } \\
\text { Interest } \\
\text { Rate } \\
\end{array}$ & $\begin{array}{c}\text { Monthly } \\
\text { Mortgage } \\
\text { Payment }\end{array}$ & $\begin{array}{c}\text { Mortgage } \\
\text { Delinquency } \\
\text { Rate } \\
\end{array}$ & $\begin{array}{c}\text { Revolving } \\
\text { Debt } \\
\text { Balance } \\
\end{array}$ & $\begin{array}{c}\text { Auto } \\
\text { Debt } \\
\text { Balance } \\
\end{array}$ & $\begin{array}{c}\text { Probability of } \\
\text { New Auto } \\
\text { Financing } \\
\end{array}$ & $\begin{array}{c}\text { Recent } \\
\text { Credit } \\
\text { Inquiries } \\
\end{array}$ & $\begin{array}{c}\text { Current } \\
\text { Credit Score } \\
(\text { FICO })\end{array}$ \\
\hline Treatment & $\begin{array}{l}-1.14 \\
(0.30)\end{array}$ & $\begin{array}{l}-125.08 \\
(24.52)\end{array}$ & $\begin{array}{l}-0.006 \\
(0.004)\end{array}$ & $\begin{array}{l}-218.37 \\
(135.40)\end{array}$ & $\begin{array}{c}91.97 \\
(54.84)\end{array}$ & $\begin{array}{c}0.004 \\
(0.002)\end{array}$ & $\begin{array}{c}0.041 \\
(0.021)\end{array}$ & $\begin{array}{l}-0.57 \\
(0.82)\end{array}$ \\
\hline $\begin{array}{l}\text { Number of Loans } \\
\text { Adjusted R-squared }\end{array}$ & $\begin{array}{c}348,259 \\
0.557 \\
\end{array}$ & $\begin{array}{c}348,259 \\
0.226 \\
\end{array}$ & $\begin{array}{c}348,259 \\
0.069 \\
\end{array}$ & $\begin{array}{c}348,259 \\
0.052 \\
\end{array}$ & $\begin{array}{c}348,259 \\
0.037 \\
\end{array}$ & $\begin{array}{c}348,259 \\
0.024 \\
\end{array}$ & $\begin{array}{c}348,259 \\
0.081 \\
\end{array}$ & $\begin{array}{c}348,259 \\
0.069 \\
\end{array}$ \\
\hline
\end{tabular}

Panel B: Two Years after Mortgage Payment Reduction

\begin{tabular}{|c|c|c|c|c|c|c|c|c|}
\hline & $\begin{array}{c}\text { Monthly } \\
\text { Interest } \\
\text { Rate } \\
\end{array}$ & $\begin{array}{c}\text { Monthly } \\
\text { Mortgage } \\
\text { Payment } \\
\end{array}$ & $\begin{array}{c}\text { Mortgage } \\
\text { Delinquency } \\
\text { Rate } \\
\end{array}$ & $\begin{array}{c}\text { Revolving } \\
\text { Debt } \\
\text { Balance } \\
\end{array}$ & $\begin{array}{c}\text { Auto } \\
\text { Debt } \\
\text { Balance } \\
\end{array}$ & $\begin{array}{c}\text { Probability of } \\
\text { New Auto } \\
\text { Financing } \\
\end{array}$ & $\begin{array}{c}\text { Recent } \\
\text { Credit } \\
\text { Inquiries } \\
\end{array}$ & $\begin{array}{c}\text { Current } \\
\text { Credit Score } \\
(\text { FICO }) \\
\end{array}$ \\
\hline Treatment & $\begin{array}{l}-1.75 \\
(0.14)\end{array}$ & $\begin{array}{c}-163.54 \\
(10.91)\end{array}$ & $\begin{array}{r}-0.018 \\
(0.01)\end{array}$ & $\begin{array}{c}-616.31 \\
(135.42)\end{array}$ & $\begin{array}{l}324.19 \\
(88.36)\end{array}$ & $\begin{array}{c}0.012 \\
(0.004)\end{array}$ & $\begin{array}{c}-0.099 \\
(0.017)\end{array}$ & $\begin{array}{c}5.68 \\
(1.14)\end{array}$ \\
\hline Number of Loans & 348,259 & 348,259 & 348,259 & 348,259 & 348,259 & 348,259 & 348,259 & 348,259 \\
\hline Adjusted R-squared & 0.891 & 0.251 & 0.064 & 0.048 & 0.037 & 0.034 & 0.083 & 0.07 \\
\hline
\end{tabular}


Table 3: Heterogeneous Treatment Effects of Mortgage Payment Reduction - By Above Median Credit Utilization Rate and CLTV

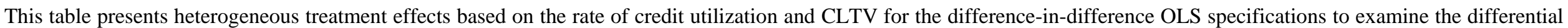

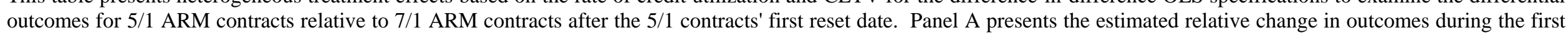

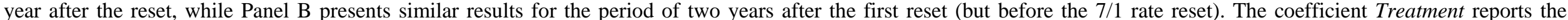

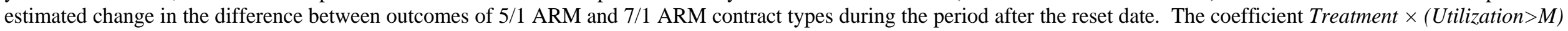

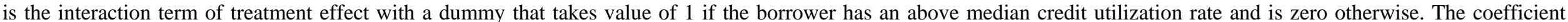

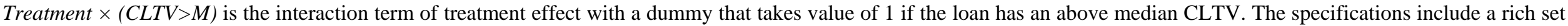

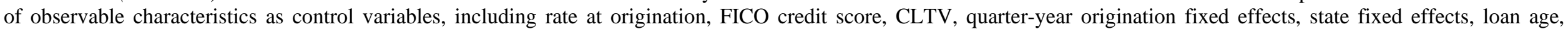
mortgage product, Utilization $>M$ and $C L T V>M$ dummies, as well as their appropriate interaction terms with other control variables.

Panel A: One Year after Mortgage Payment Reduction

\begin{tabular}{|c|c|c|c|c|c|c|}
\hline & $\begin{array}{c}\text { Monthly } \\
\text { Mortgage } \\
\text { Payment } \\
\end{array}$ & $\begin{array}{c}\text { Mortgage } \\
\text { Delinquency } \\
\text { Rate } \\
\end{array}$ & $\begin{array}{c}\text { Revolving } \\
\text { Debt } \\
\text { Balance } \\
\end{array}$ & $\begin{array}{c}\text { Auto } \\
\text { Debt } \\
\text { Balance } \\
\end{array}$ & $\begin{array}{c}\text { Probability of } \\
\text { New Auto } \\
\text { Financing } \\
\end{array}$ & $\begin{array}{c}\text { Current } \\
\text { Credit Score } \\
\text { (FICO) }\end{array}$ \\
\hline Treatment & $\begin{array}{l}-113.84 \\
(23.27)\end{array}$ & $\begin{array}{r}-0.001 \\
(0.00)\end{array}$ & $\begin{array}{c}244.43 \\
(108.54)\end{array}$ & $\begin{array}{l}-15.06 \\
(66.47)\end{array}$ & $\begin{array}{c}0.002 \\
(0.003)\end{array}$ & $\begin{array}{l}-0.773 \\
(0.29)\end{array}$ \\
\hline Treatment $\times($ Utilization $>M)$ & $\begin{array}{l}-13.43 \\
(7.39)\end{array}$ & $\begin{array}{r}-0.006 \\
(0.00)\end{array}$ & $\begin{array}{l}-835.68 \\
(162.51)\end{array}$ & $\begin{array}{l}-151.30 \\
(50.65)\end{array}$ & $\begin{array}{c}-0.004 \\
(0.002)\end{array}$ & $\begin{array}{l}-0.98 \\
(1.02)\end{array}$ \\
\hline Treatment $\times(\mathrm{CLTV}>\mathrm{M})$ & $\begin{array}{c}-19.189 \\
(8.58)\end{array}$ & $\begin{array}{r}-0.008 \\
(0.00)\end{array}$ & $\begin{array}{l}-223.38 \\
(130.39)\end{array}$ & $\begin{array}{l}258.77 \\
(\mathbf{8 7 . 9 8 )}\end{array}$ & $\begin{array}{c}0.009 \\
(0.003)\end{array}$ & $\begin{array}{l}2.407 \\
(0.40)\end{array}$ \\
\hline $\begin{array}{l}\text { Number of Loans } \\
\text { Adjusted R-squared }\end{array}$ & $\begin{array}{c}348,259 \\
0.233 \\
\end{array}$ & $\begin{array}{c}348,259 \\
0.074 \\
\end{array}$ & $\begin{array}{c}348,259 \\
0.254 \\
\end{array}$ & $\begin{array}{c}348,259 \\
0.044 \\
\end{array}$ & $\begin{array}{c}348,259 \\
0.042 \\
\end{array}$ & $\begin{array}{c}348,259 \\
0.469 \\
\end{array}$ \\
\hline
\end{tabular}

Panel B: Two Years after Mortgage Payment Reduction

\begin{tabular}{|c|c|c|c|c|c|c|}
\hline & $\begin{array}{c}\text { Monthly } \\
\text { Mortgage } \\
\text { Payment } \\
\end{array}$ & $\begin{array}{c}\text { Mortgage } \\
\text { Delinquency } \\
\text { Rate } \\
\end{array}$ & $\begin{array}{c}\text { Revolving } \\
\text { Debt } \\
\text { Balance } \\
\end{array}$ & $\begin{array}{c}\text { Auto } \\
\text { Debt } \\
\text { Balance } \\
\end{array}$ & $\begin{array}{c}\text { Probability of } \\
\text { New Auto } \\
\text { Financing } \\
\end{array}$ & $\begin{array}{c}\text { Current } \\
\text { Credit Score } \\
\text { (FICO) }\end{array}$ \\
\hline Treatment & $\begin{array}{c}-160.03 \\
(9.00)\end{array}$ & $\begin{array}{l}-0.003 \\
(0.00)\end{array}$ & $\begin{array}{c}147.89 \\
(175.74)\end{array}$ & $\begin{array}{c}81.83 \\
(124.62)\end{array}$ & $\begin{array}{c}0.014 \\
(0.004)\end{array}$ & $\begin{array}{l}1.135 \\
(0.72)\end{array}$ \\
\hline Treatment $\times($ Utilization $>M)$ & $\begin{array}{l}-4.115 \\
(5.60)\end{array}$ & $\begin{array}{r}-0.020 \\
(0.01)\end{array}$ & $\begin{array}{l}-1116.89 \\
(170.45)\end{array}$ & $\begin{array}{c}-69.90 \\
(136.51)\end{array}$ & $\begin{array}{l}-0.003 \\
(0.004)\end{array}$ & $\begin{array}{l}5.061 \\
(1.01)\end{array}$ \\
\hline Treatment $\times($ CLTV $>M)$ & $\begin{array}{l}1.002 \\
(5.23)\end{array}$ & $\begin{array}{r}-0.013 \\
(0.00)\end{array}$ & $\begin{array}{c}-59.09 \\
(249.51)\end{array}$ & $\begin{array}{c}343.75 \\
(149.39)\end{array}$ & $\begin{array}{c}0.011 \\
(0.005)\end{array}$ & $\begin{array}{l}3.549 \\
(1.06)\end{array}$ \\
\hline $\begin{array}{l}\text { Number of Loans } \\
\text { Adjusted R-squared }\end{array}$ & $\begin{array}{c}348,259 \\
0.257\end{array}$ & $\begin{array}{c}348,259 \\
0.07\end{array}$ & $\begin{array}{c}348,259 \\
0.232\end{array}$ & $\begin{array}{c}348,259 \\
0.043\end{array}$ & $\begin{array}{c}348,259 \\
0.004\end{array}$ & $\begin{array}{c}348,259 \\
0.451\end{array}$ \\
\hline
\end{tabular}


Table 4: Treatment Effect of Reduction in Mortgage Payments on Debt Deleveraging

\section{Borrowers in the Top Quartile of Credit Utilization Rates and the Bottom Quartile of Credit Scores}

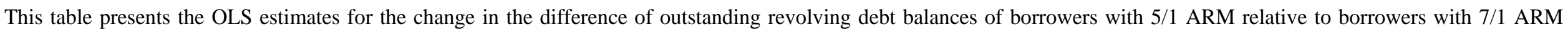

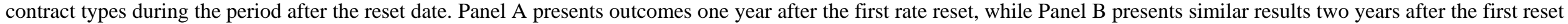

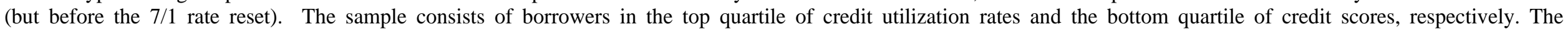

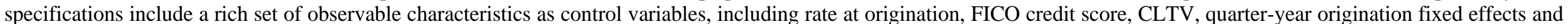
state fixed effects. Standard errors clustered by quarter of origination are in parentheses.

Panel A: One Year after Mortgage Payment Reduction

\begin{tabular}{ccc}
\hline \hline & $\begin{array}{c}\text { Top Quartile } \\
\text { Credit Utilization }\end{array}$ & $\begin{array}{c}\text { Bottom Quartile } \\
\text { Credit Score }\end{array}$ \\
Relative Change in Revolving Debt in the First Year & $-\$ 1285$ & $-\$ 1206$ \\
$(280.65)$ & $(321.40)$ & $70.6 \%$ \\
\hline \hline
\end{tabular}

Panel B: Two Years after Mortgage Payment Reduction

\begin{tabular}{ccc}
\hline \hline Relative Change in Revolving Debt over Two Years & $\begin{array}{c}\text { Top Quartile } \\
\text { Credit Utilization }\end{array}$ & $\begin{array}{c}\text { Bottom Quartile } \\
\text { Credit Score }\end{array}$ \\
\hline As \% of Reduction in Mortgage Payments over Two Years & $-\$ 1548$ & $-\$ 1257$ \\
$(337.85)$ & $40.0 \%$ & $31.7 \%$ \\
\hline \hline
\end{tabular}




\section{Table 5: Regional Evidence: Zip Code Summary Statistics, Mortgage Interest Rate, and ARM Share}

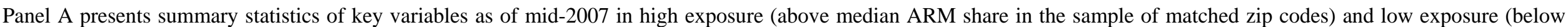

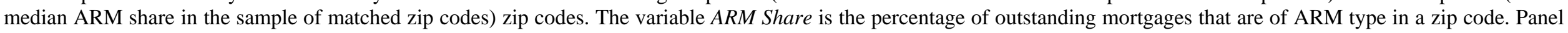

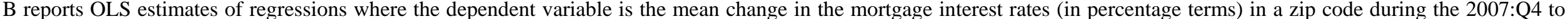

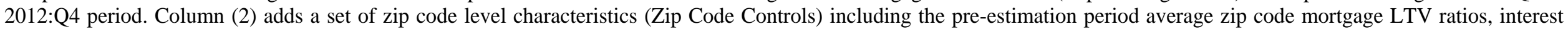

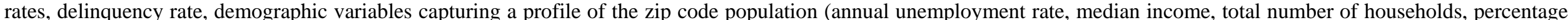

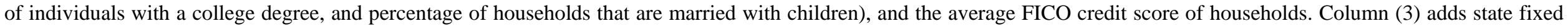
effects. The estimates are expressed in percentage terms; standard errors are in parentheses.

Panel A: Summary Statistics for High and Low Exposure Zip Codes

\begin{tabular}{|c|c|c|c|c|}
\hline & \multicolumn{2}{|c|}{ "High Exposure Zip Codes } & \multicolumn{2}{|c|}{ Low Exposure Zip Codes } \\
\hline & Mean & S.D. & Mean & S.D. \\
\hline FICO & 714.8 & 23.2 & 716.0 & 18.9 \\
\hline LTV & 64.5 & 7.29 & 68.1 & 7.00 \\
\hline Interest Rate & 6.64 & 0.57 & 6.68 & 0.48 \\
\hline Mortgage Delinquency Rate & 2.81 & 3.09 & 2.23 & 1.83 \\
\hline Unemployment Rate & 6.04 & 1.55 & 5.91 & 1.47 \\
\hline Median Income & 58.42 & 14.13 & 52.77 & 14.38 \\
\hline Percentage of Individuals with College Degree & 31.4 & 10.1 & 29.5 & 9.42 \\
\hline Percentage of Households that are Married Couples with Children & 21.9 & 5.13 & 21.6 & 5.13 \\
\hline Consumer Credit Score & 3.37 & 0.41 & 3.35 & 0.35 \\
\hline ARM Share & 35.2 & 7.62 & 17.3 & 4.51 \\
\hline
\end{tabular}

Panel B: Zip Code ARM Share and Change in a Zip Code Mortgage Interest Rate

\begin{tabular}{lccc}
\hline \hline & $(1)$ & $(2)$ & $(3)$ \\
\hline ARM Share & $\mathbf{- 0 . 0 1 9 8}$ & $\mathbf{- 0 . 0 1 7 6}$ & $\mathbf{- 0 . 0 1 7 4}$ \\
& $\mathbf{( 0 . 0 0 0 5 )}$ & $\mathbf{( 0 . 0 0 0 6 )}$ & $\mathbf{( 0 . 0 0 0 8 )}$ \\
Zip Code Controls & No & Yes & Yes \\
& & & \\
State FE & No & No & Yes \\
\hline Number of Zip Codes & 1000 & 902 & 902 \\
R-Squared & 0.568 & 0.759 & 0.800 \\
\hline \hline
\end{tabular}


Table 6: Mortgage Delinquency, House Price, and Auto Sales Growth and the Zip Code ARM Share

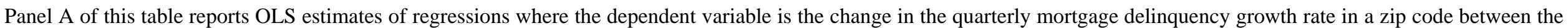

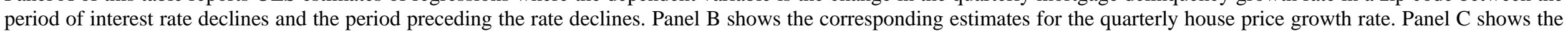

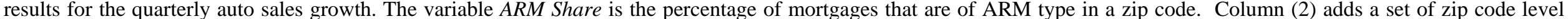
characteristics. Column (3) adds state fixed effects. The estimates are expressed in percentage terms; standard errors are in parentheses.

Panel A: Change in the Mortgage Delinquency Growth Rate and the Zip Code ARM Share

\begin{tabular}{lccc}
\hline \hline & $(1)$ & $(2)$ & $(3)$ \\
\hline & $\mathbf{- 0 . 6 5 7}$ & $\mathbf{- 0 . 5 7 9}$ & $\mathbf{- 0 . 2 6 9}$ \\
ARM Share & $\mathbf{( 0 . 0 4 8 )}$ & $\mathbf{( 0 . 0 6 7 )}$ & $\mathbf{( 0 . 0 9 2 )}$ \\
Zip Code Controls & No & Yes & Yes \\
State FE & No & No & Yes \\
\hline Number of Zip Codes & 1000 & 902 & 902 \\
R-Squared & 0.156 & 0.305 & 0.426 \\
\hline \hline
\end{tabular}

Panel B: Change in the House Price Growth Rate and the Zip Code ARM Share

\begin{tabular}{lccc}
\hline \hline & $(1)$ & $(2)$ & $(3)$ \\
\hline ARM Share & $\mathbf{0 . 0 3 1 9}$ & $\mathbf{0 . 0 2 5 1}$ & $\mathbf{0 . 0 2 5 8}$ \\
& $\mathbf{( 0 . 0 0 5 )}$ & $\mathbf{( 0 . 0 0 6 )}$ & $\mathbf{( 0 . 0 0 5 )}$ \\
Zip Code Controls & No & Yes & Yes \\
State FE & No & No & Yes \\
\hline Number of Zip Codes & 1000 & 902 & 902 \\
R-Squared & 0.035 & 0.313 & 0.497 \\
\hline \hline
\end{tabular}

Panel C: Change in the Auto Sales Growth Rate and the Zip Code ARM Share

\begin{tabular}{lccc}
\hline \hline & $(1)$ & $(2)$ & $(3)$ \\
\hline & $\mathbf{0 . 0 8 5}$ & $\mathbf{0 . 0 8 8}$ & $\mathbf{0 . 0 3 7}$ \\
ARM Share & $\mathbf{( 0 . 0 0 8 )}$ & $\mathbf{( 0 . 0 1 3 )}$ & $\mathbf{( 0 . 0 1 8 )}$ \\
Zip Code Controls & No & Yes & Yes \\
State FE & No & No & Yes \\
\hline Number of Zip Codes & 1000 & 902 & 902 \\
R-Squared & 0.089 & 0.154 & 0.282 \\
\hline \hline
\end{tabular}




\section{Table 7: Employment Growth and the Zip Code ARM Share}

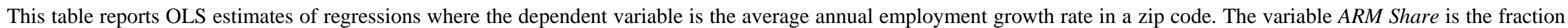

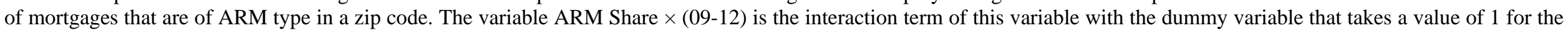

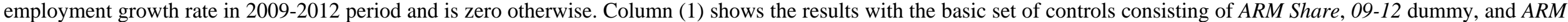

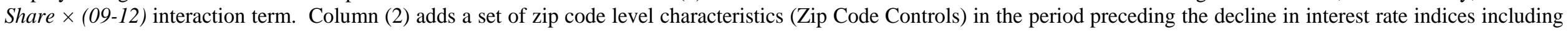

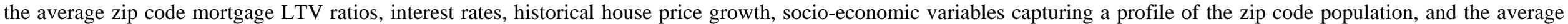

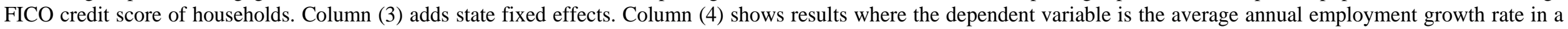

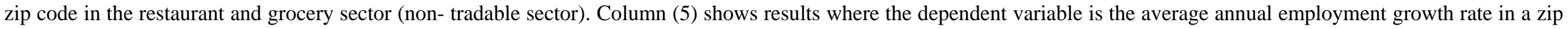
code in the tradable sector. The estimation period: 2007-2012. The estimates are expressed in percentage terms; standard errors are in parentheses.

\begin{tabular}{|c|c|c|c|c|c|}
\hline & $\begin{array}{c}\text { All Industries } \\
\text { Employment } \\
\text { Growth Rate } \\
\text { (1) }\end{array}$ & $\begin{array}{c}\text { All Industries } \\
\text { Employment } \\
\text { Growth Rate } \\
\text { (2) }\end{array}$ & $\begin{array}{l}\text { All Industries } \\
\text { Employment } \\
\text { Growth Rate } \\
\text { (3) }\end{array}$ & $\begin{array}{c}\text { Restaurant and Grocery } \\
\text { Employment } \\
\text { Growth Rate } \\
(4)\end{array}$ & $\begin{array}{c}\text { Tradable Sector } \\
\text { Employment } \\
\text { Growth Rate } \\
\text { (5) }\end{array}$ \\
\hline ARM Share & $\begin{array}{c}-0.0557^{* * *} \\
(0.0131)\end{array}$ & $\begin{array}{c}-0.0873^{* * *} \\
(0.0166)\end{array}$ & $\begin{array}{c}-0.00559 \\
(0.0219)\end{array}$ & $\begin{array}{c}0.00643 \\
(0.0425)\end{array}$ & $\begin{array}{c}0.0693 \\
(0.304)\end{array}$ \\
\hline ARM Share $\times(09-12)$ & $\begin{array}{c}0.0902^{* * *} \\
(0.0185)\end{array}$ & $\begin{array}{c}0.0891^{* * *} \\
(0.0186)\end{array}$ & $\begin{array}{c}0.0891^{* * *} \\
(0.0183)\end{array}$ & $\begin{array}{l}\mathbf{0 . 0 7 1 1}^{* *} \\
(0.0351)\end{array}$ & $\begin{array}{c}-0.0018 \\
(0.253)\end{array}$ \\
\hline Zip Code Controls & No & Yes & Yes & Yes & Yes \\
\hline State FE & No & No & Yes & Yes & Yes \\
\hline Number of Zip Codes & 1000 & 902 & 902 & 829 & 878 \\
\hline R-Squared & 0.0999 & 0.123 & 0.173 & 0.0648 & 0.0555 \\
\hline
\end{tabular}




\section{Figure 1: The Impact of Rate Resets: Mortgage Interest Rates and Scheduled Mortgage Payments}

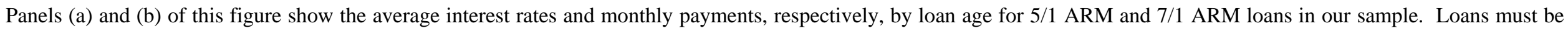

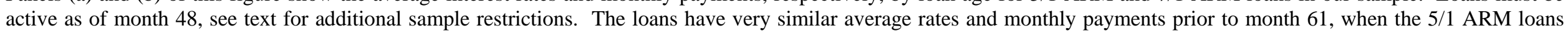

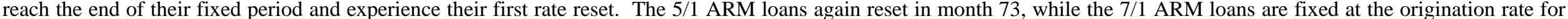

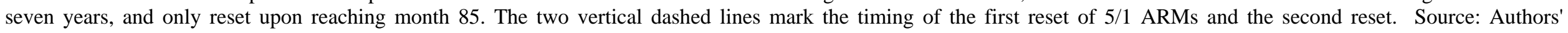
calculations using data from the large secondary market participant.

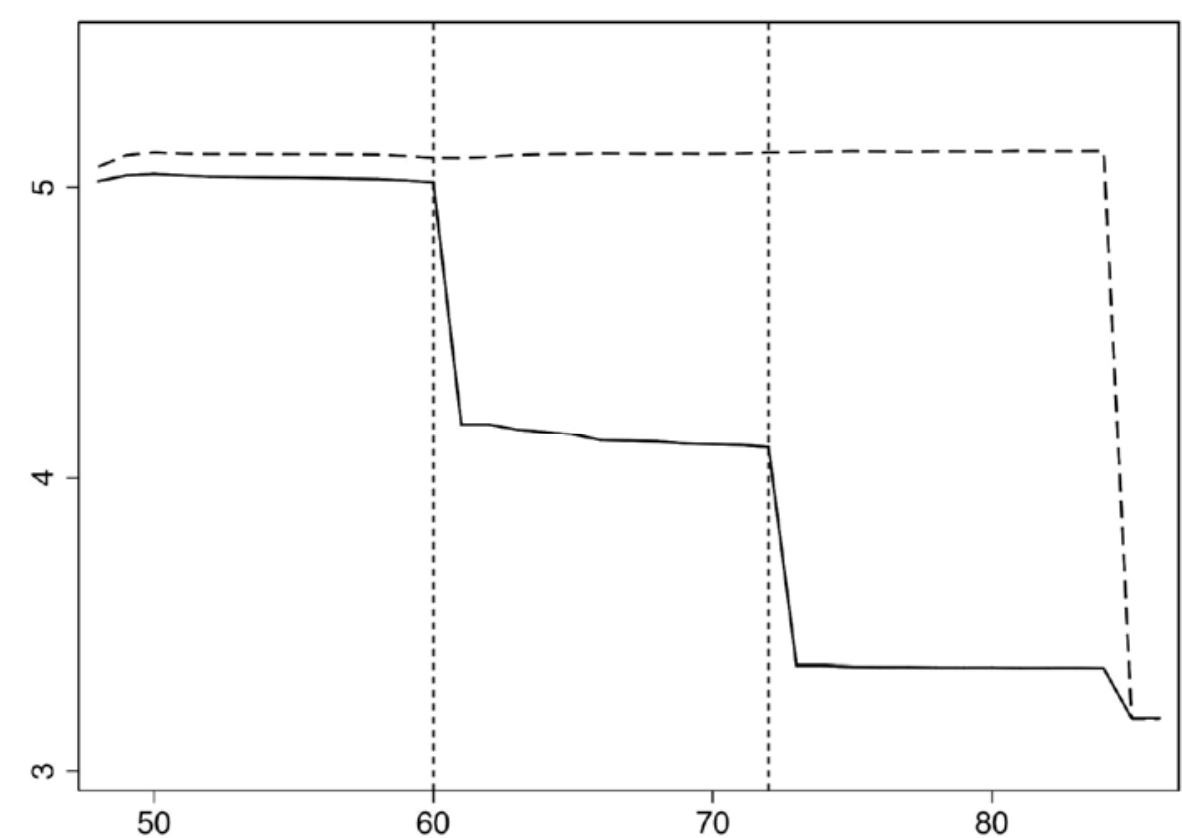

(a) Interest Rates

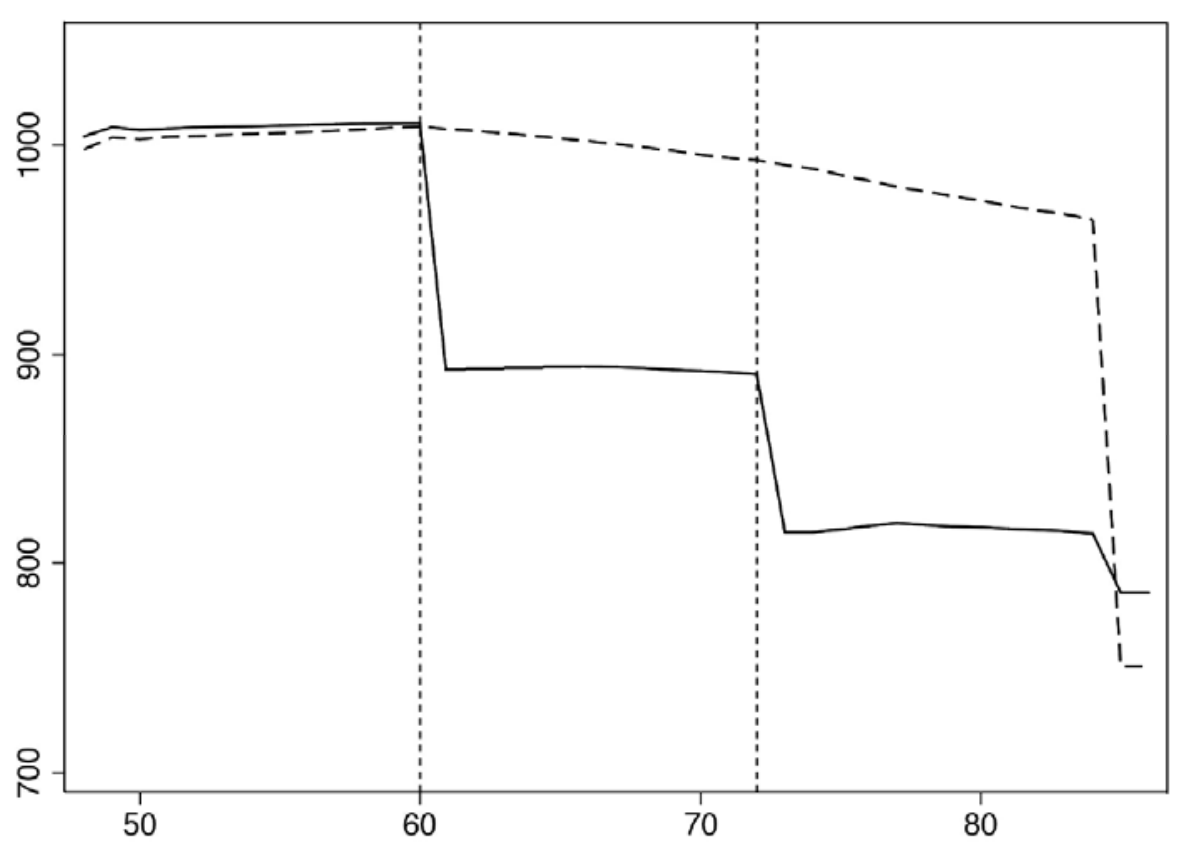

(b) Monthly Mortgage Payments 
Figure 2: Impact of Mortgage Payment Reduction on Revolving Debt Balance

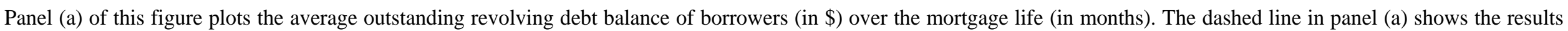

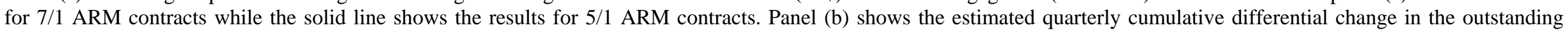

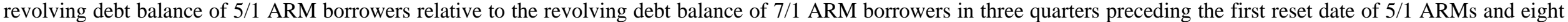

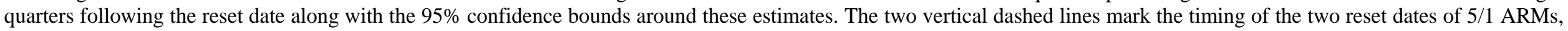

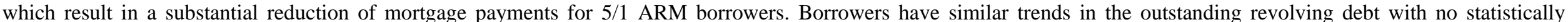

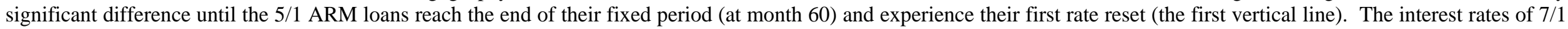

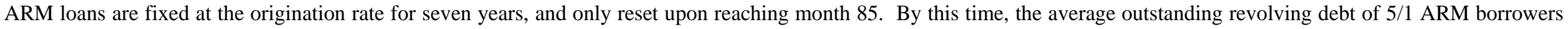
has declined significantly relative to those of 7/1 ARM borrowers. Source: Authors' calculations using data from the large secondary market participant.

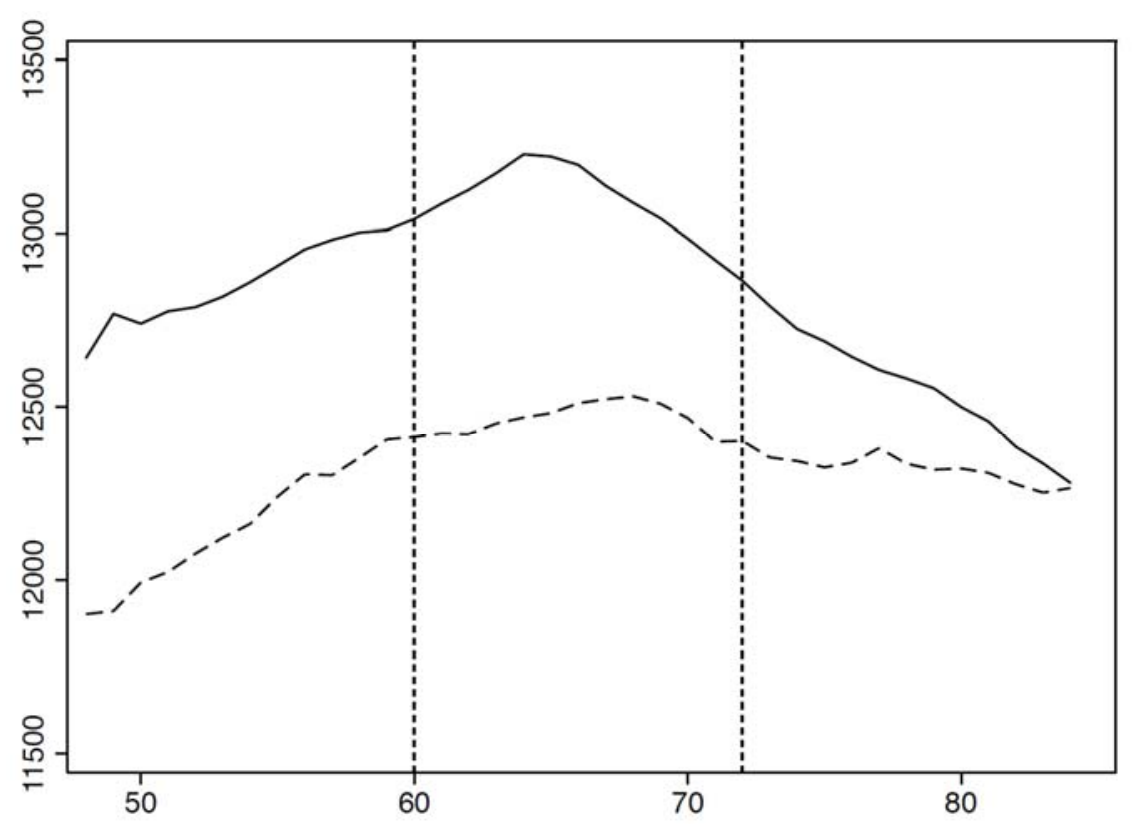

(a) Revolving Debt Balance (Monthly)

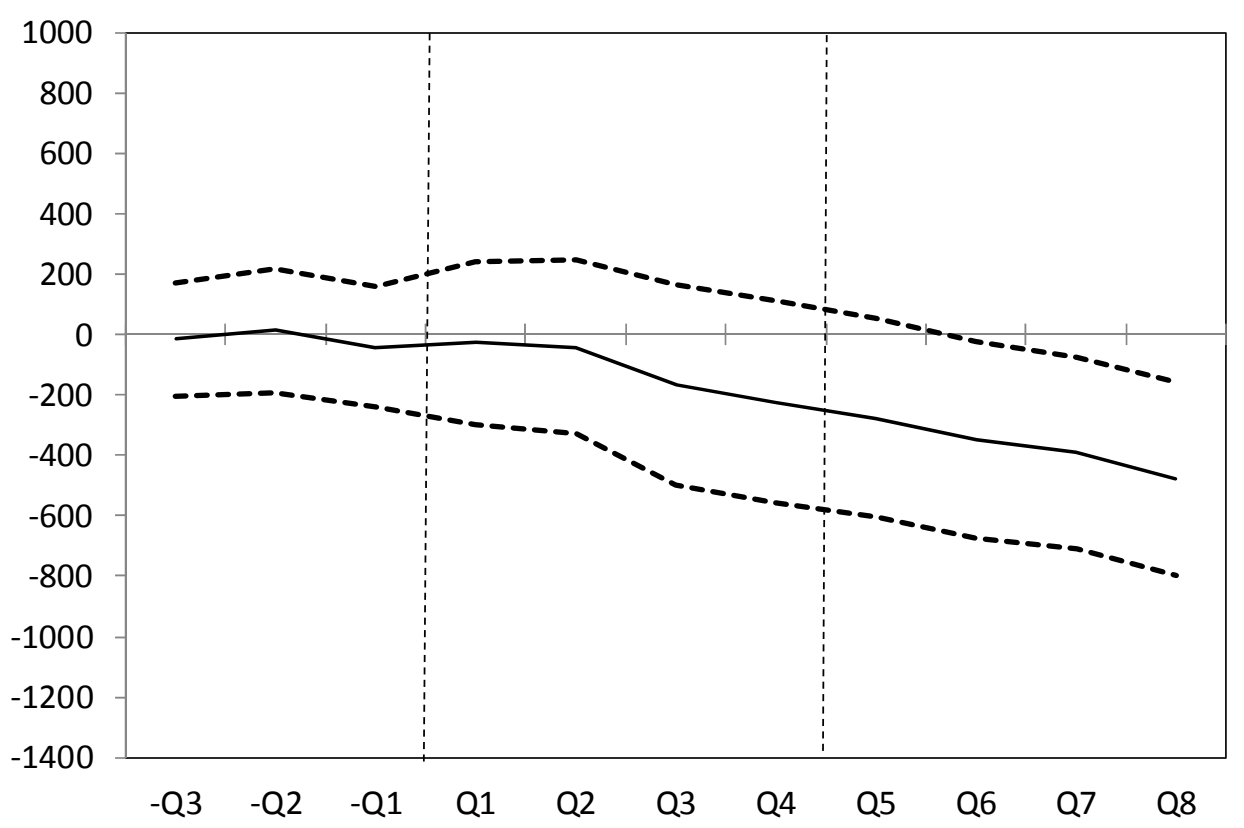

(b) Cumulative Quarterly Differential Change in the Revolving Debt Balance 


\section{Figure 3: Impact of Mortgage Payment Reduction on Durable Consumption (Auto) Financing}

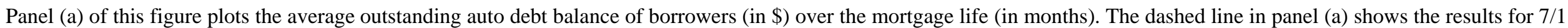

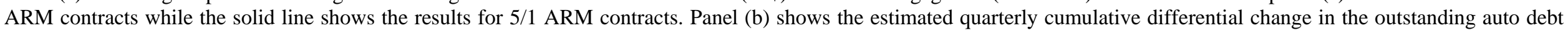

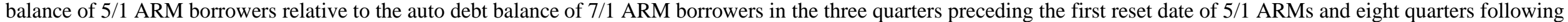

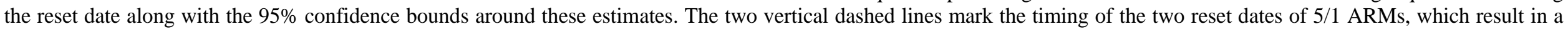

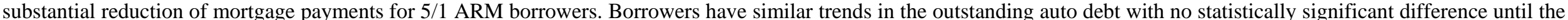

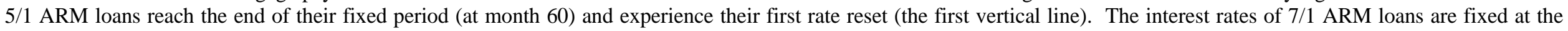

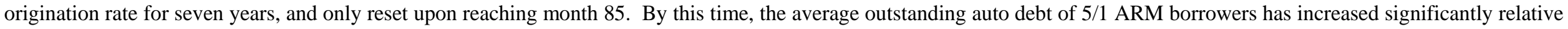
to those of 7/1 ARM borrowers. Source: Authors' calculations using data from the large secondary market participant.

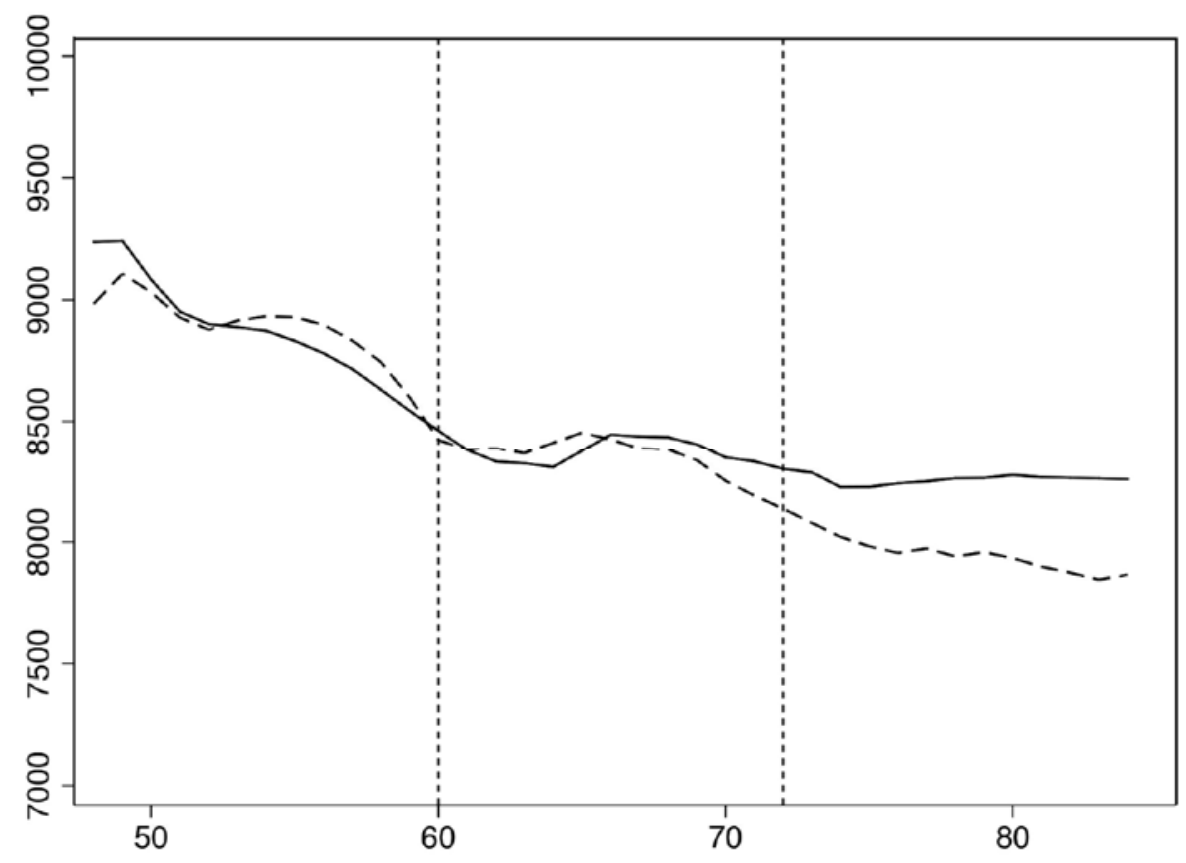

(a) Auto Debt Balance (Monthly)

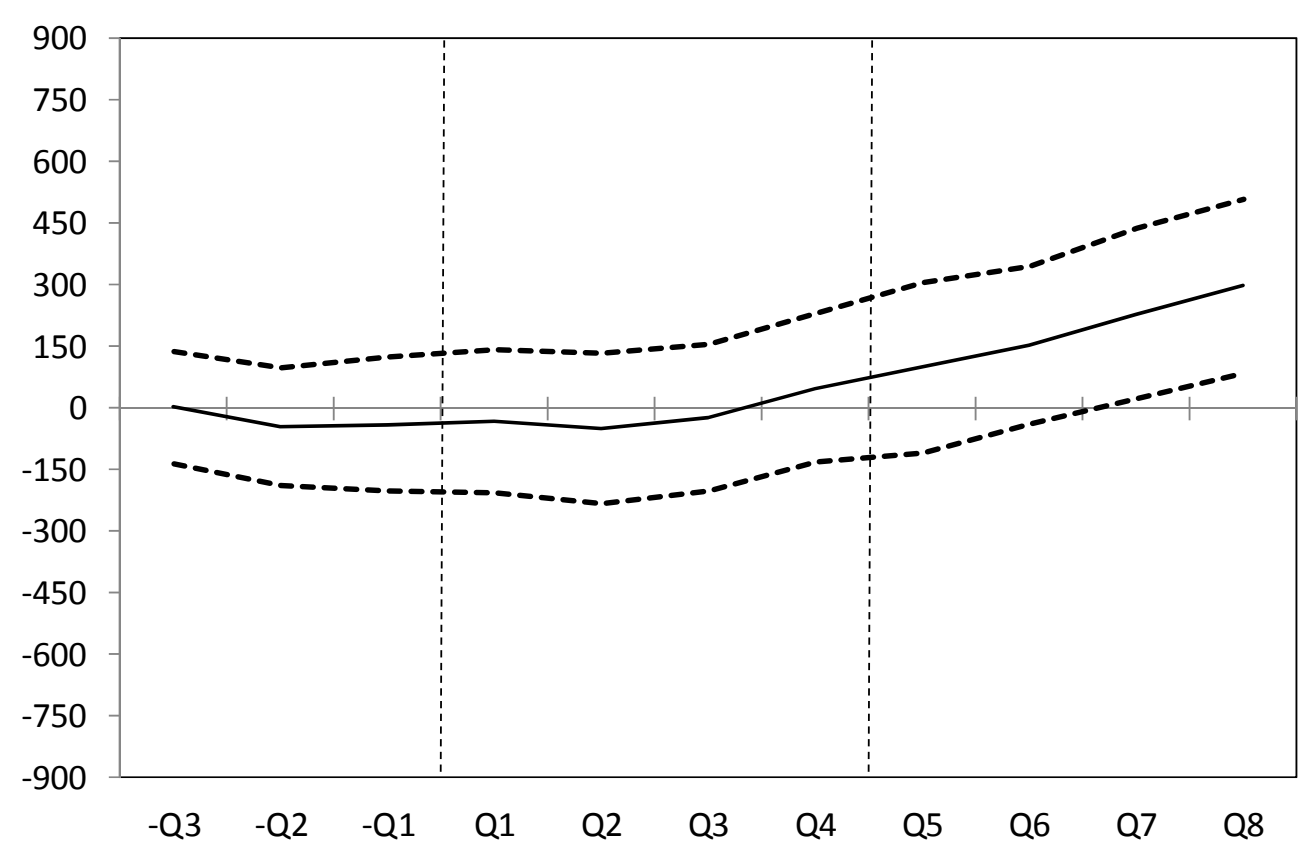

(b) Cumulative Quarterly Differential Change in Auto Debt Balance 


\section{Figure 4: Impact of Mortgage Payment Reduction on Quarterly Probability of New Durable Consumption (Auto) Financing}

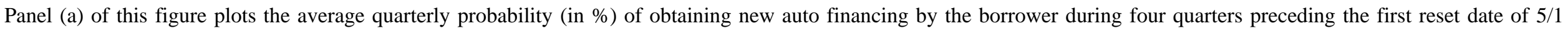

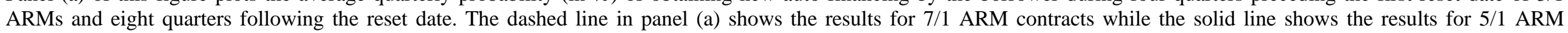

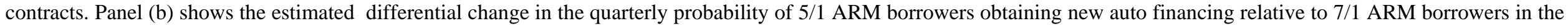

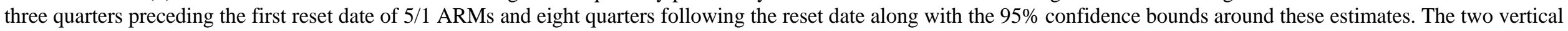

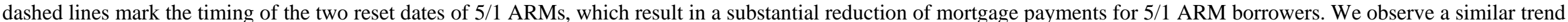

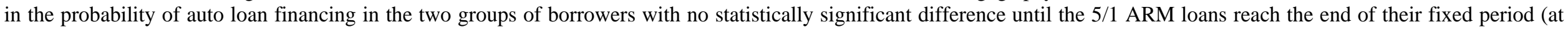

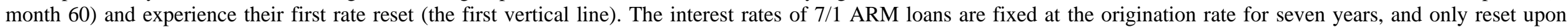

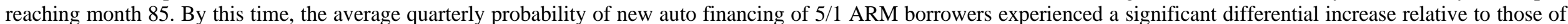

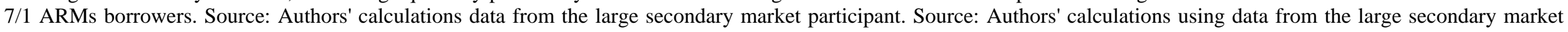
participant.

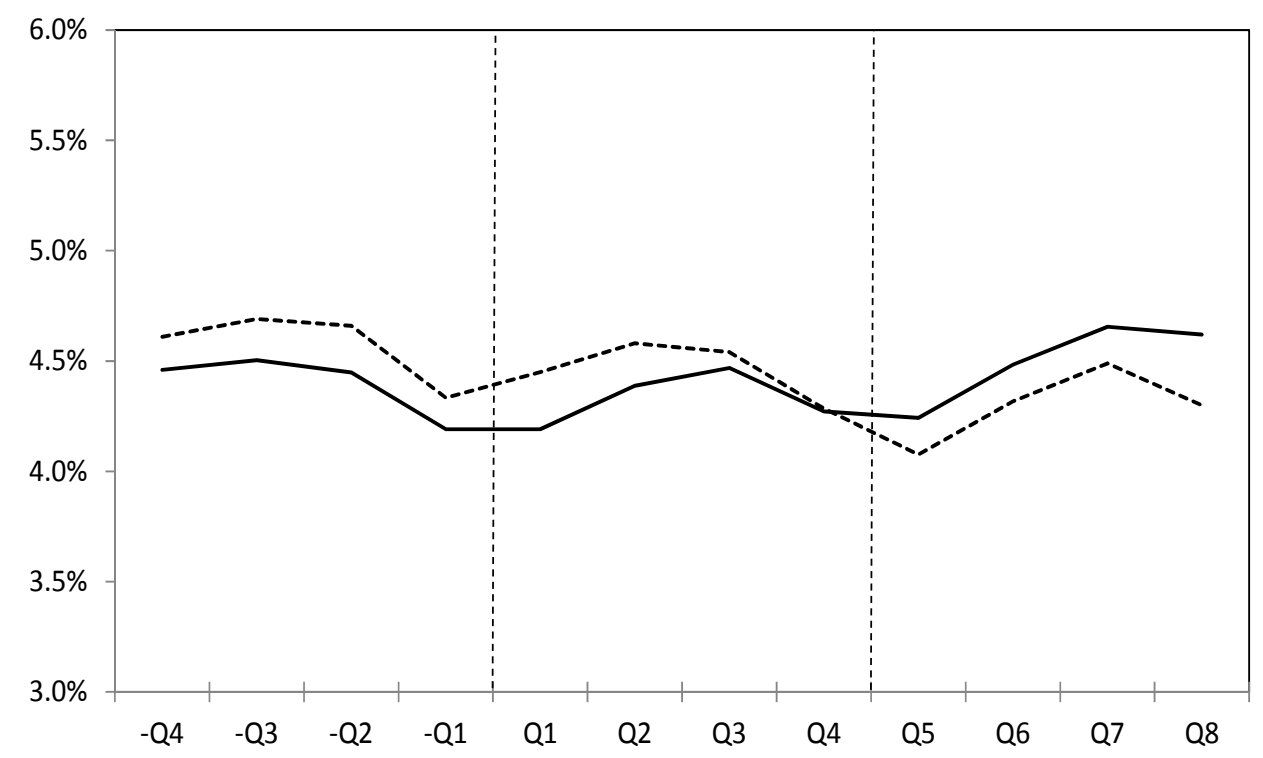

(a) Quarterly Probability of New Auto Financing

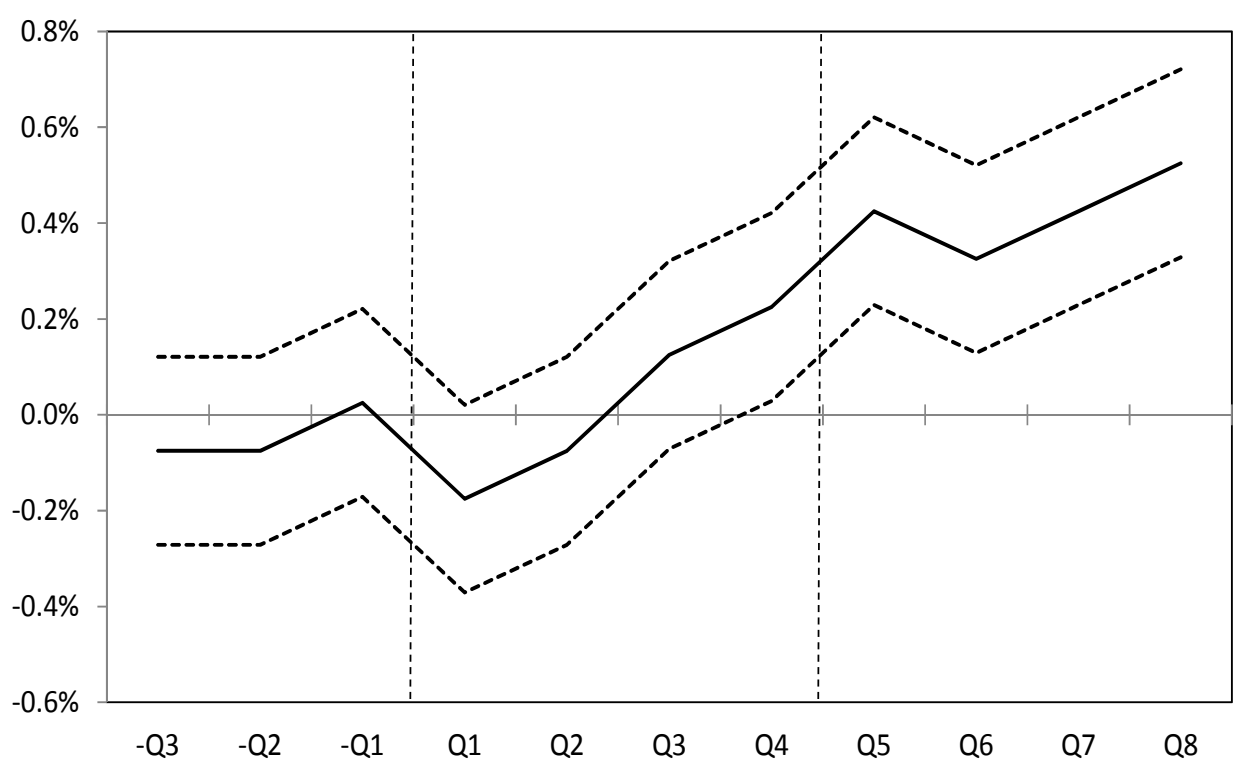

(b) Differential Change in the Quarterly Probability of New Auto Financing 


\section{Figure 5: Geographic Distribution of Zip Codes}

This figure presents the geographic distribution of zip codes in our overall sample across the United States (panel a) and in California (panel b). In addition, the figure displays the percentage of loans in a zip code which are of ARM type (the zip code ARM share). As we observe, there is a significant variation in the ARM share across zip codes (ranging from just few percent of loans being of ARM type in a zip code to more than 60\%).

Panel A: Distribution of Zip Codes across the United States

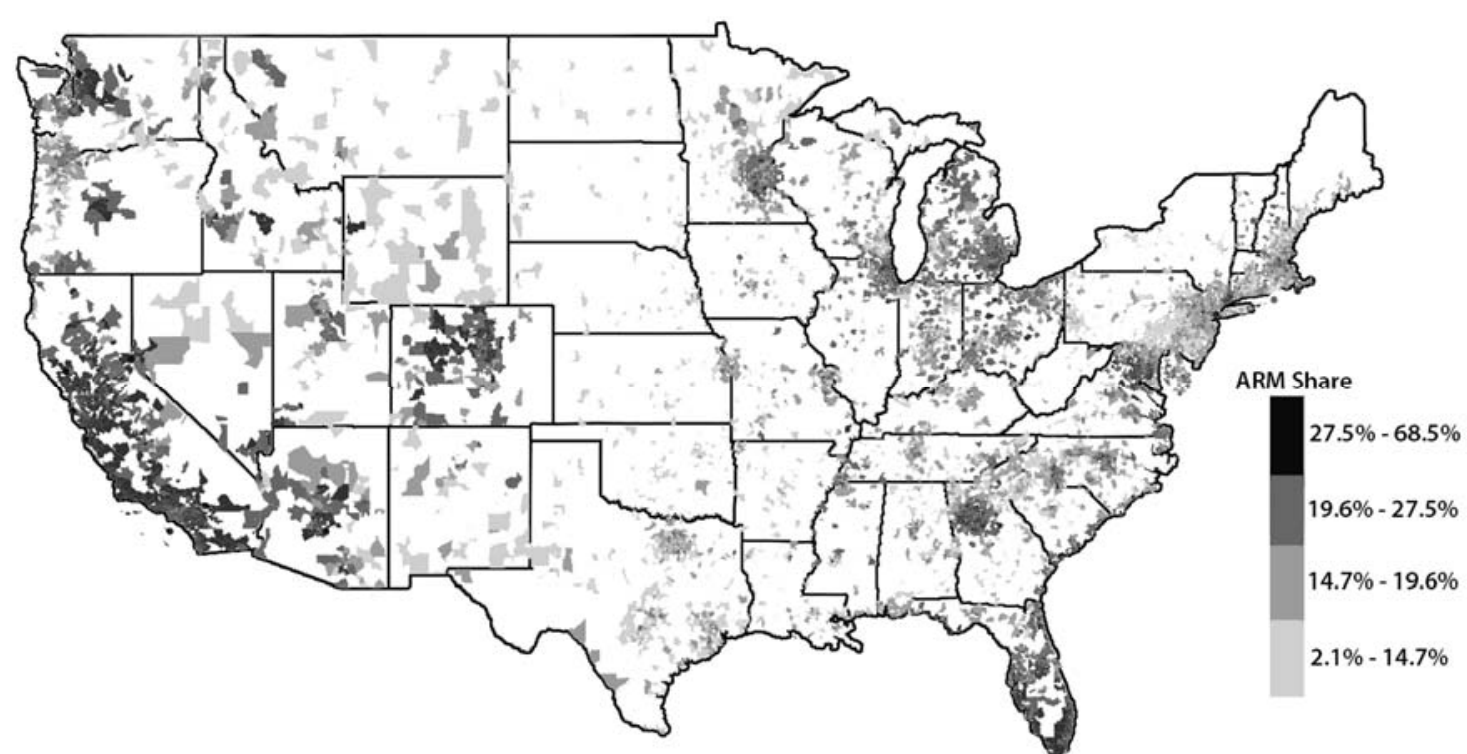

Panel B: Distribution of Zip Codes in California

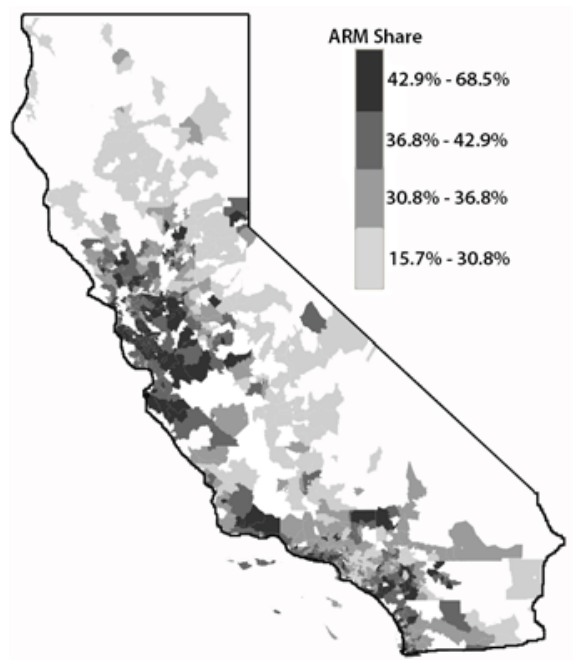

49 


\section{Figure 6: Evolution of Observables in High and Low Exposure Zip Codes}

The figure shows the evolution of the mean origination FICO credit score (panel a), current mortgage interest rate (panel b), and origination LTV ratio (panel c) of outstanding mortgages in high and low exposure zip codes prior to the decline in interest rate indices. The high and low exposure groups are defined based on the share of loans that are ARMs in a zip code. The high exposure group is represented by the solid line and the low exposure group is represented by the dashed line.

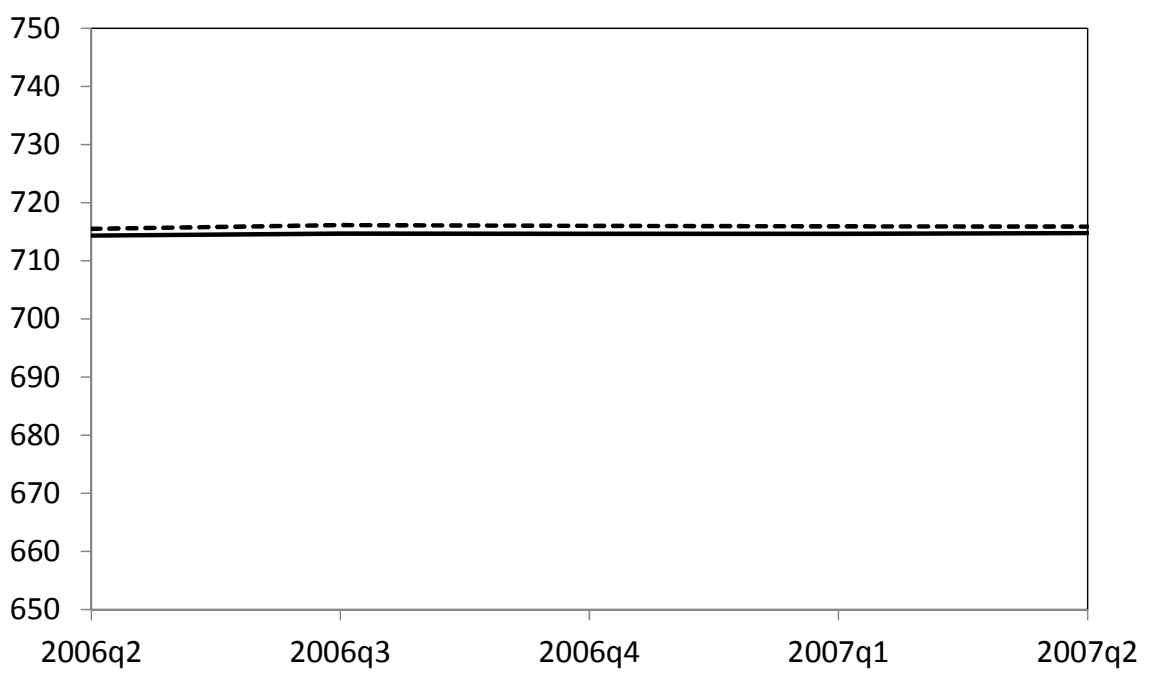

(a) FICO Credit Score

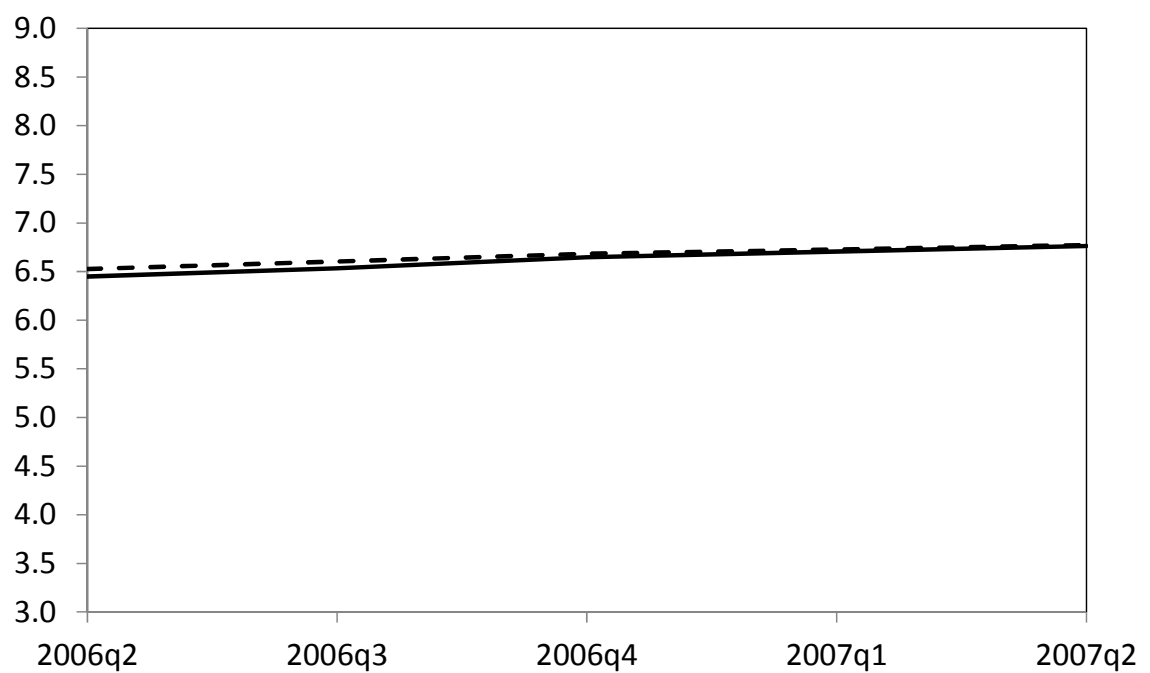

(b) Mortgage Interest Rate

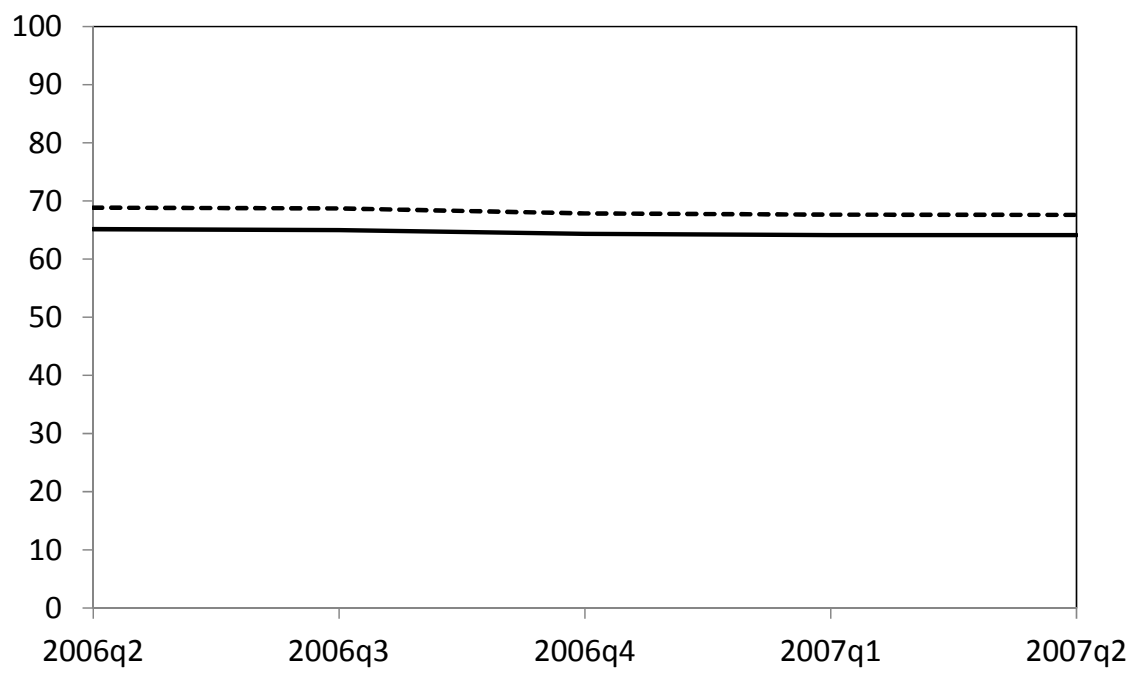

(c) LTV Ratio 


\section{Figure 7: Interest Rate Indices and Mean Zip Code Mortgage Interest Rates in High and Low Exposure Zip Codes}

This figure presents the evolution of index interest rates (panel a) and the evolution of average zip code mortgage interest rates (panel b). The high and low exposure groups in panel (b) are defined based on the share of loans that are ARMs in a zip code. In panel (b), the high exposure group is represented by the solid line and the low exposure group is represented by the dashed line. The first vertical dashed line (at 2007:Q2) marks the period of the beginning of the rapid decline in interest rate indices, while the second (at 2008:Q1) marks the beginning of the period when we start observing the divergence in mortgage interest rates across high and low exposure zip codes.

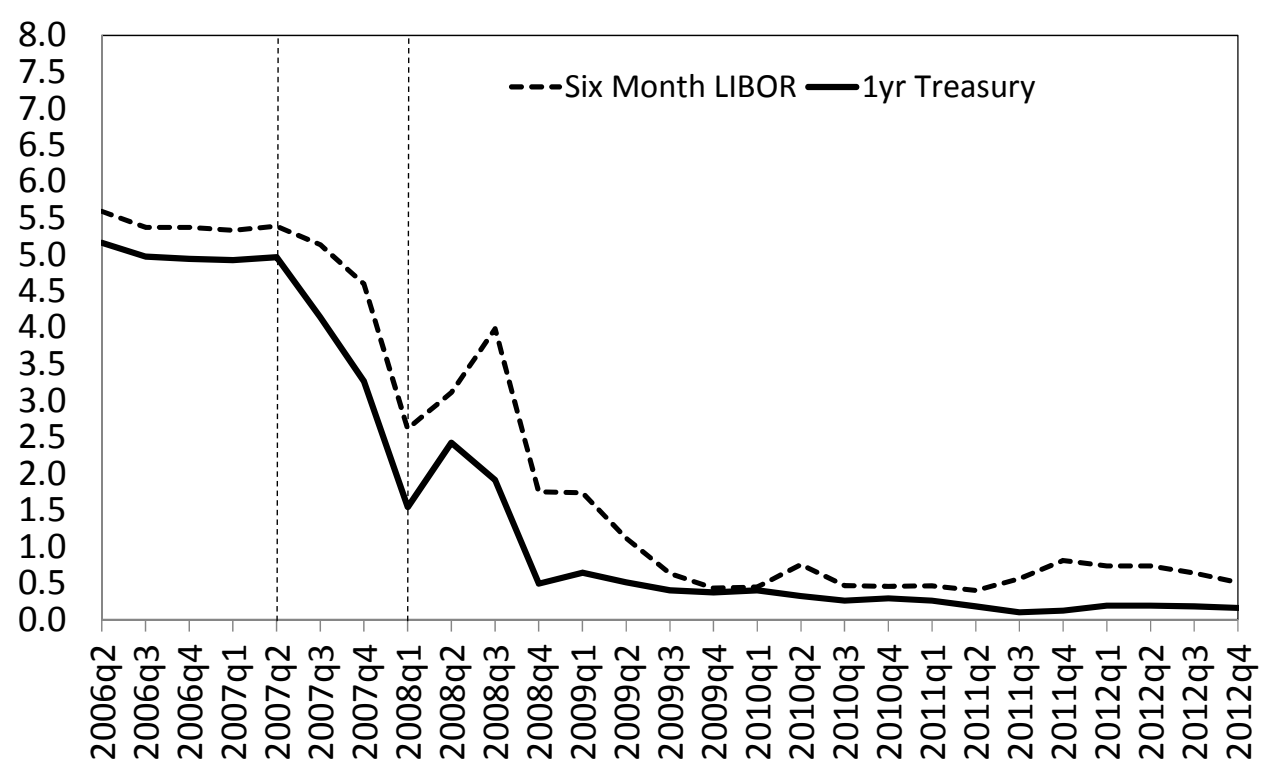

(a) 6-month LIBOR and 1-year Treasury

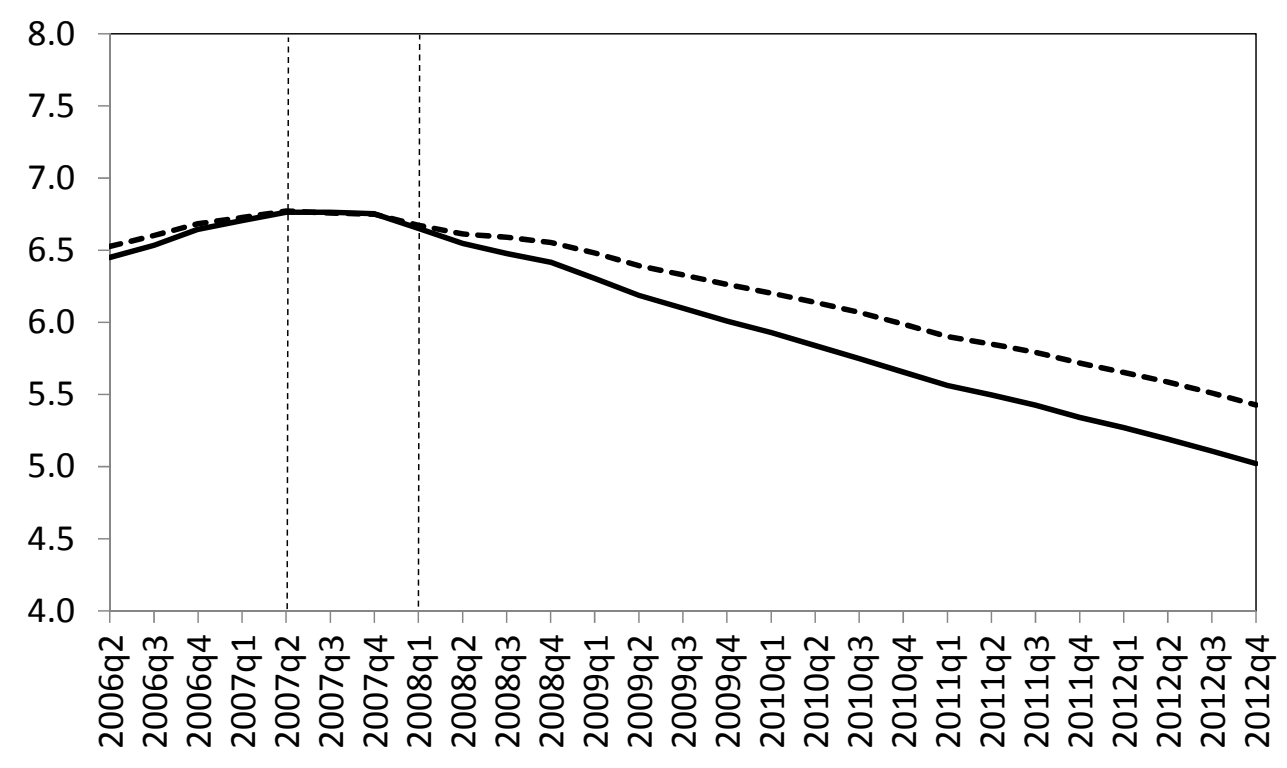

(b) Zip Code Mortgage Interest Rates 
Figure 8: Mortgage Delinquency, House Prices, Auto Sales, and Employment in High and Low Exposure Zip Codes

The figure shows the average quarterly growth rate (in \%) of the mortgage delinquency rate (panel a), the average quarterly house price growth rate (panel b), the annual auto sales growth rate (panel c), and the annual employment growth rate (panel d) in high and low exposure zip codes. The high and low exposure groups are defined based on the share of loans that are ARMs in a zip code. The high exposure group is represented by the solid line and the low exposure group is represented by the dashed line. The vertical dashed line marks the beginning of the period when we start observing the divergence in mortgage interest rates across high and low exposure zip codes following the decline in the interest rate indices.

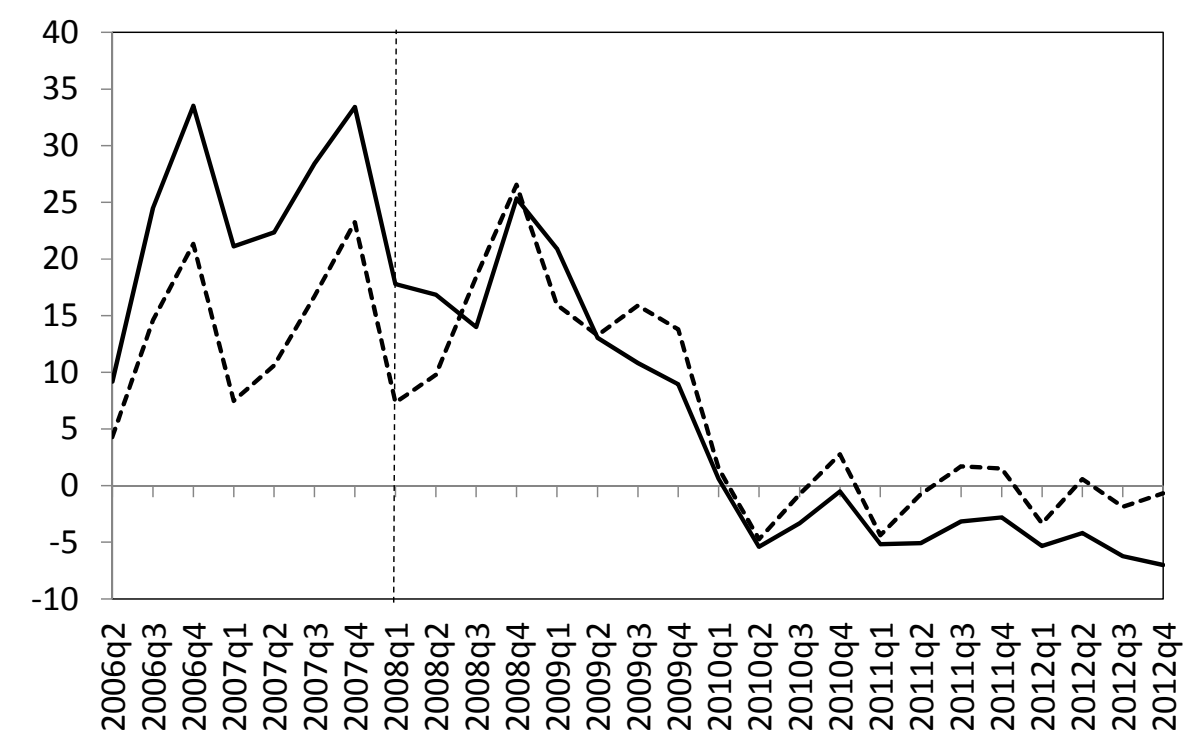

(a) Mortgage Delinquency Growth

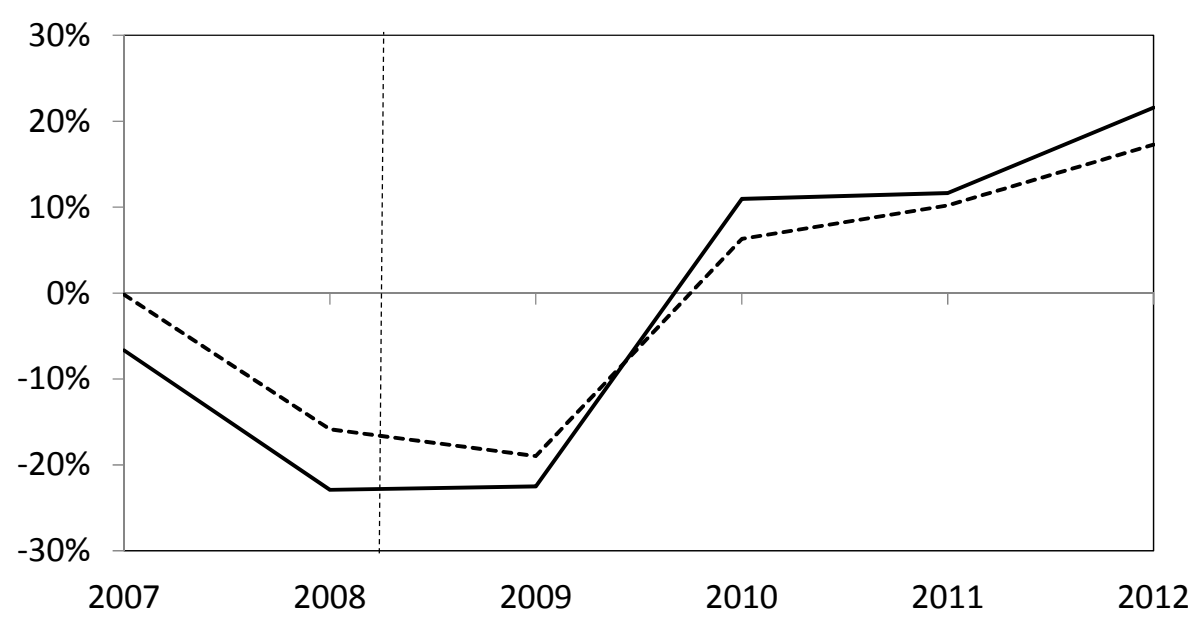

(c) Auto Sales Growth

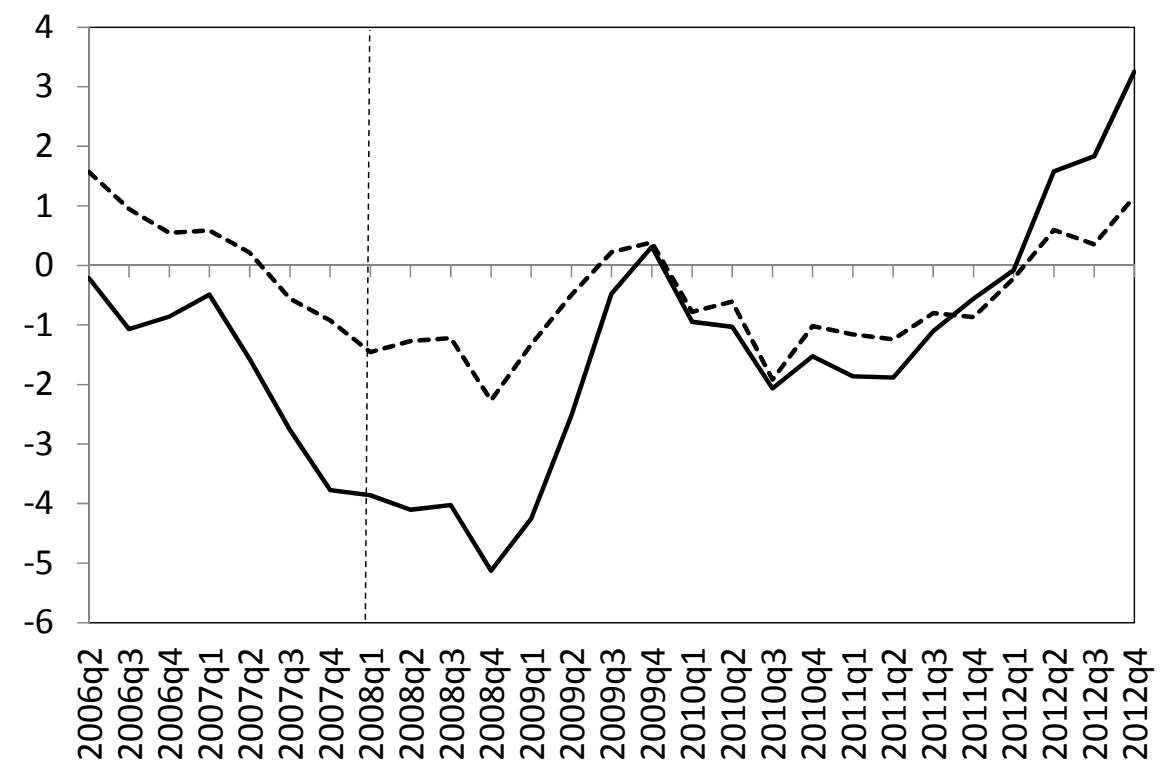

(b) House Price Growth

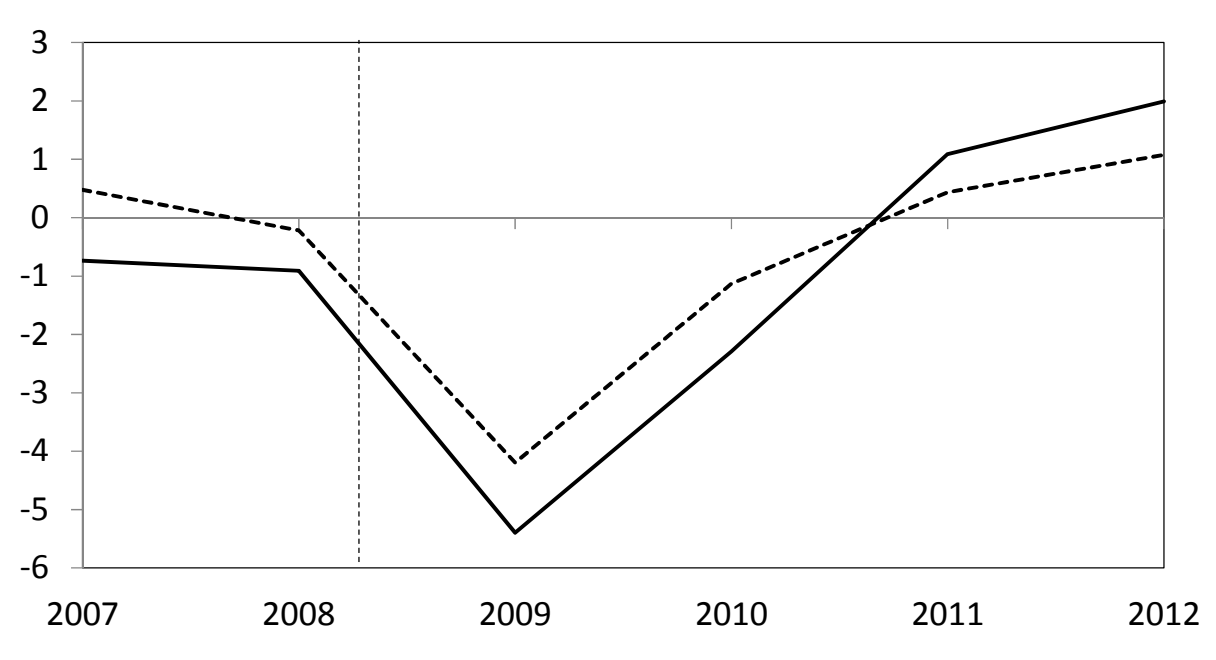

(d) Employment Growth 
Appendix 


\section{A1: Impact of Mortgage Payment Reduction on the Delinquency Rate of Mortgages, Revolving Debt, and Auto Debt}

This figure plots the average cumulative monthly delinquency rate for mortgages (panel a), revolving debt (panel b), and auto debt (panel c). The dashed line shows the results for 7/1 ARM contracts while the solid line shows the results for 5/1 ARM contracts. The two vertical dashed lines mark the timing of the two reset dates of 5/1 ARMs, which result in a substantial reduction of mortgage payments for 5/1 ARM borrowers.
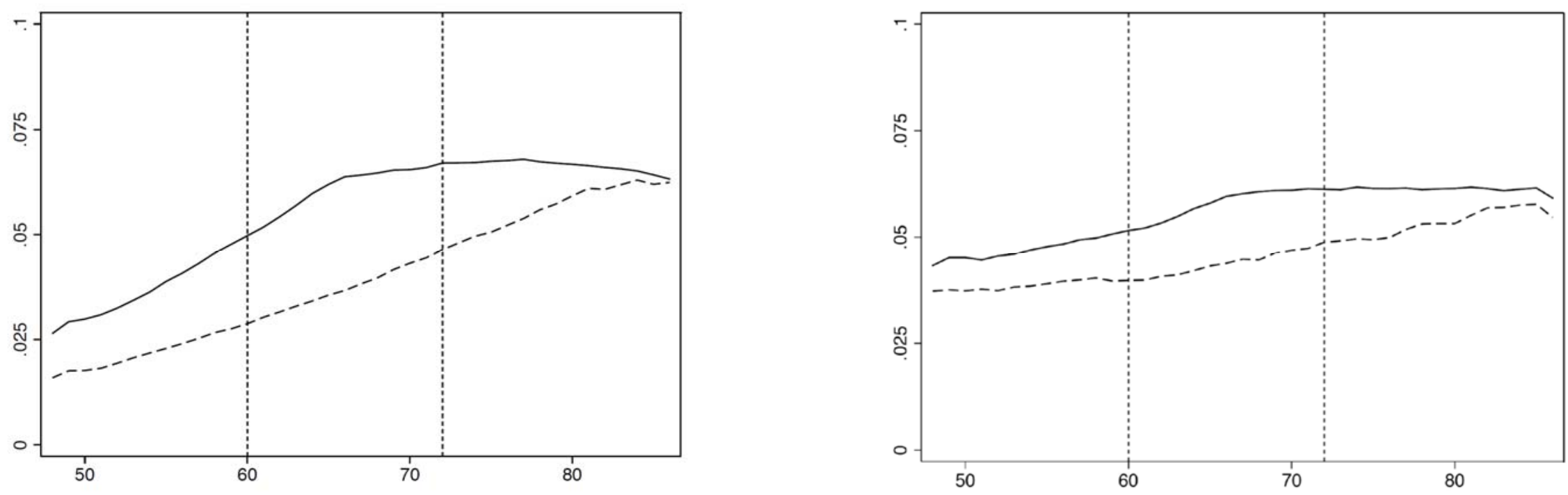

(a) Mortgage Delinquency Rate

(b) Revolving Delinquency Rate

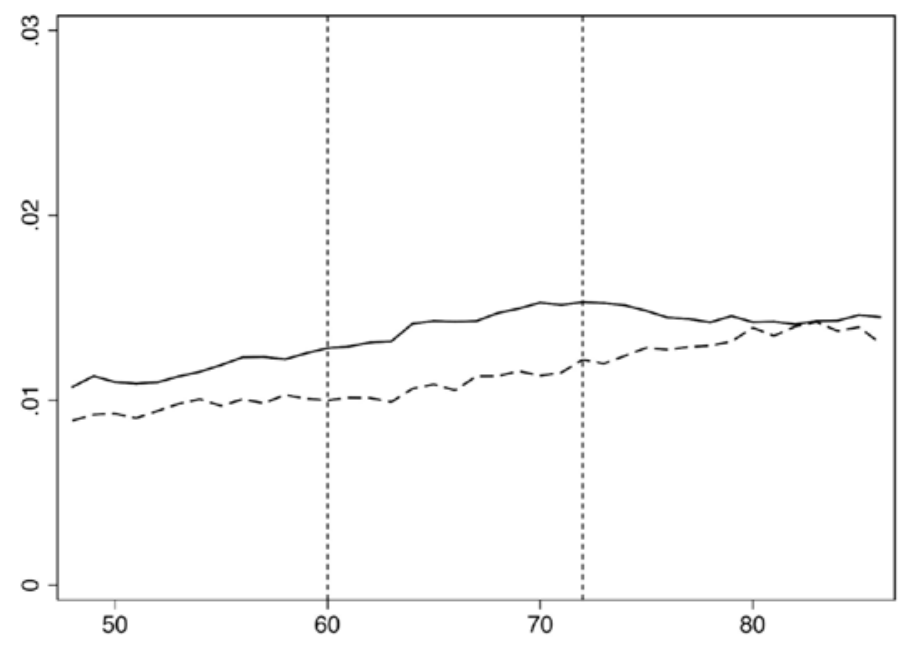

(c) Auto Delinquency Rate 


\section{A2: Impact of Mortgage Payment Reduction on Credit Inquires, Credit Utilization Rate, and Consumer Credit Score}

This figure plots the evolution of the average of recent credit inquires (panel a), credit utilization rate (panel b), and FICO consumer credit score (panel c). The dashed line shows the results for 7/1 ARM contracts while the solid line shows the results for 5/1 ARM contracts. The two vertical dashed lines mark the timing of the two reset dates of 5/1 ARMs, which result in a substantial reduction of mortgage payments for 5/1 ARM borrowers.
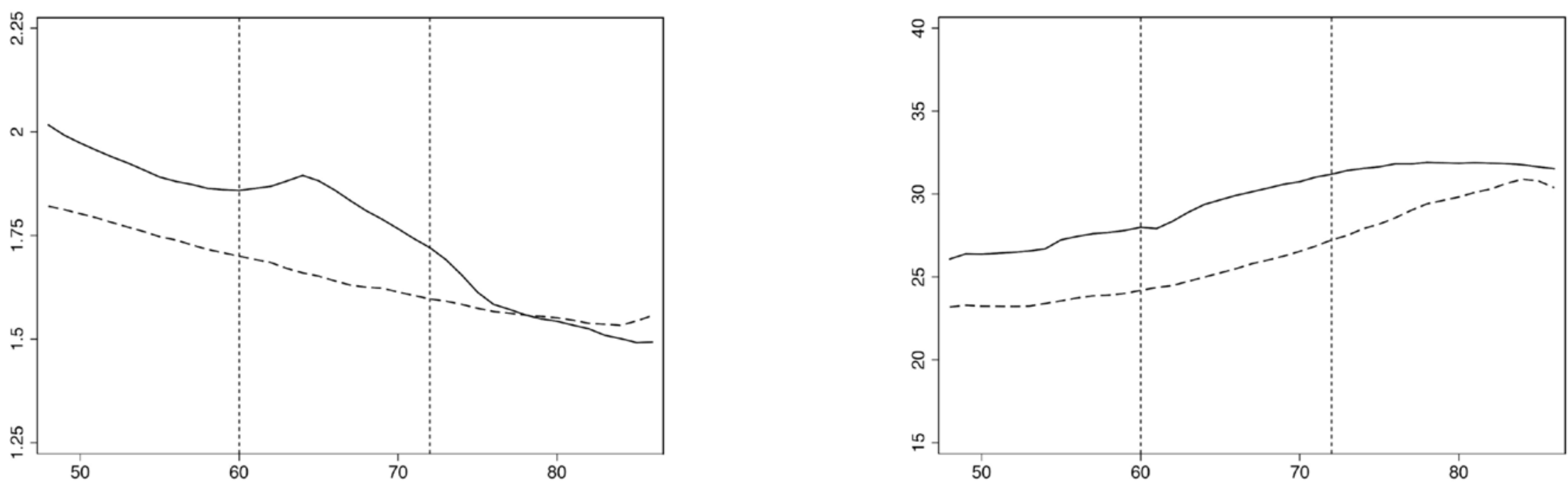

(a) Recent Credit Inquiries

(b) Credit Utilization Rate

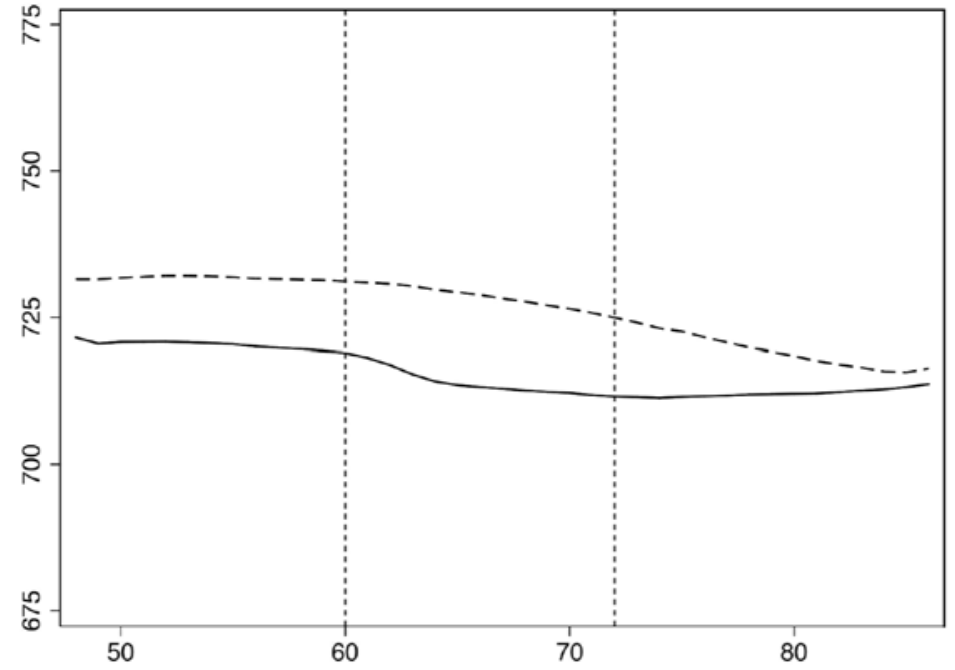

(c) FICO 


\section{A3: Heterogeneous Treatment Effects - By Above/Below Median Credit Utilization Rate}

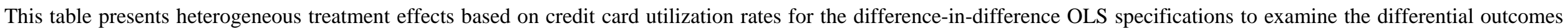

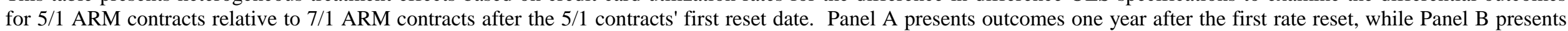

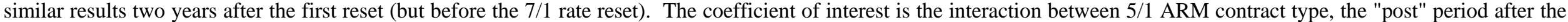

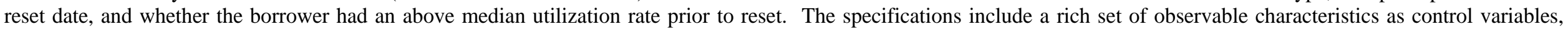

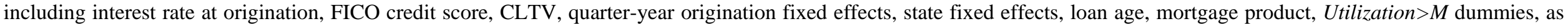
well as their appropriate interaction terms with other control variables. Standard errors clustered by quarter of origination are in parentheses.

Panel A: Heterogeneous Treatment Effects One Year after Reduction in Mortgage Payments

\begin{tabular}{|c|c|c|c|c|c|}
\hline & $\begin{array}{c}\text { Monthly } \\
\text { Mortgage } \\
\text { Payment } \\
\end{array}$ & $\begin{array}{c}\text { Mortgage } \\
\text { Delinquency } \\
\text { Rate } \\
\end{array}$ & $\begin{array}{c}\text { Revolving } \\
\text { Debt } \\
\text { Balance } \\
\end{array}$ & $\begin{array}{c}\text { Auto } \\
\text { Debt } \\
\text { Balance } \\
\end{array}$ & $\begin{array}{c}\text { Probability of } \\
\text { New Auto } \\
\text { Financing } \\
\end{array}$ \\
\hline Treatment & $\begin{array}{l}-117.53 \\
(23.44)\end{array}$ & $\begin{array}{l}-0.003 \\
(0.001)\end{array}$ & $\begin{array}{c}21.56 \\
(81.582)\end{array}$ & $\begin{array}{c}62.07 \\
(54.98)\end{array}$ & $\begin{array}{c}0.006 \\
(0.003)\end{array}$ \\
\hline Treatment $\times($ Utilization $>M)$ & $\begin{array}{c}-16.212 \\
(8.16)\end{array}$ & $\begin{array}{c}-0.007 \\
(0.001)\end{array}$ & $\begin{array}{c}-867.48 \\
(169.873)\end{array}$ & $\begin{array}{l}-116.70 \\
(53.40)\end{array}$ & $\begin{array}{c}-0.004 \\
(0.005)\end{array}$ \\
\hline $\begin{array}{l}\text { Number of Loans } \\
\text { Adjusted R-squared }\end{array}$ & $\begin{array}{c}348,259 \\
0.227\end{array}$ & $\begin{array}{c}348,259 \\
0.074\end{array}$ & $\begin{array}{c}348,259 \\
0.254\end{array}$ & $\begin{array}{c}348,259 \\
0.044\end{array}$ & $\begin{array}{c}348,259 \\
0.027\end{array}$ \\
\hline
\end{tabular}

Panel B: Heterogeneous Treatment Effects Two Years after Reduction in Mortgage Payments

\begin{tabular}{|c|c|c|c|c|c|}
\hline & $\begin{array}{c}\text { Monthly } \\
\text { Mortgage } \\
\text { Payment }\end{array}$ & $\begin{array}{c}\text { Mortgage } \\
\text { Delinquency } \\
\text { Rate } \\
\end{array}$ & $\begin{array}{c}\text { Revolving } \\
\text { Debt } \\
\text { Balance } \\
\end{array}$ & $\begin{array}{c}\text { Auto } \\
\text { Debt } \\
\text { Balance }\end{array}$ & $\begin{array}{c}\text { Probability of } \\
\text { New Auto } \\
\text { Financing }\end{array}$ \\
\hline Treatment & $\begin{array}{c}-159.74 \\
(9.32)\end{array}$ & $\begin{array}{r}-0.007 \\
(\mathbf{0 . 0 0 )}\end{array}$ & $\begin{array}{c}136.35 \\
(92.798)\end{array}$ & $\begin{array}{l}179.984 \\
(100.50)\end{array}$ & $\begin{array}{c}0.014 \\
(0.004)\end{array}$ \\
\hline Treatment $\times($ Utilization $>M)$ & $\begin{array}{l}-4.673 \\
(6.08)\end{array}$ & $\begin{array}{r}-0.022 \\
(0.01)\end{array}$ & $\begin{array}{l}-1131.61 \\
(174.90)\end{array}$ & $\begin{array}{c}-25.5 \\
(141.12)\end{array}$ & $\begin{array}{c}-0.003 \\
(0.004)\end{array}$ \\
\hline $\begin{array}{l}\text { Number of Loans } \\
\text { Adjusted R-squared }\end{array}$ & $\begin{array}{c}348,259 \\
0.252\end{array}$ & $\begin{array}{c}348,259 \\
0.069\end{array}$ & $\begin{array}{c}348,259 \\
0.232\end{array}$ & $\begin{array}{c}348,259 \\
0.043\end{array}$ & $\begin{array}{c}348,259 \\
0.08\end{array}$ \\
\hline
\end{tabular}




\section{A4: Heterogeneous Treatment Effects - By Above/Below Median FICO Score}

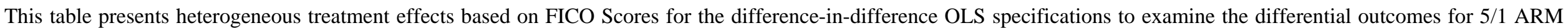

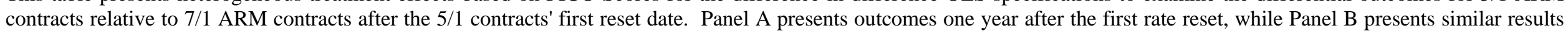

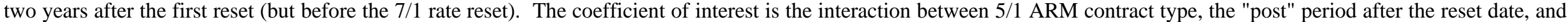

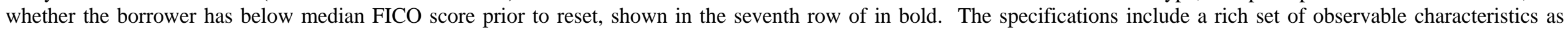

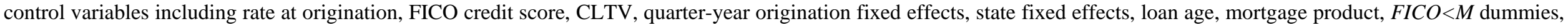
as well as their appropriate interaction terms with other control variables. Standard errors clustered by quarter of origination are in parentheses.

Panel A: Heterogeneous Treatment Effects One Year after Reduction in Mortgage Payments

\begin{tabular}{|c|c|c|c|c|c|}
\hline & $\begin{array}{c}\text { Monthly } \\
\text { Mortgage } \\
\text { Payment } \\
\end{array}$ & $\begin{array}{c}\text { Mortgage } \\
\text { Delinquency } \\
\text { Rate } \\
\end{array}$ & $\begin{array}{c}\text { Revolving } \\
\text { Debt } \\
\text { Balance } \\
\end{array}$ & $\begin{array}{c}\text { Auto } \\
\text { Debt } \\
\text { Balance } \\
\end{array}$ & $\begin{array}{c}\text { Probability of } \\
\text { New Auto } \\
\text { Financing } \\
\end{array}$ \\
\hline Treatment & $\begin{array}{l}-115.66 \\
(23.13)\end{array}$ & $\begin{array}{l}-0.001 \\
(0.00)\end{array}$ & $\begin{array}{l}310.680 \\
(90.795)\end{array}$ & $\begin{array}{c}177.076 \\
(67.00)\end{array}$ & $\begin{array}{c}0.005 \\
(0.003)\end{array}$ \\
\hline Treatment $\times($ FICO $<M)$ & $\begin{array}{c}-19.734 \\
(7.89)\end{array}$ & $\begin{array}{l}-0.012 \\
(0.01)\end{array}$ & $\begin{array}{l}-899.851 \\
(154.962)\end{array}$ & $\begin{array}{c}-293.164 \\
(76.38)\end{array}$ & $\begin{array}{l}-0.004 \\
(0.002)\end{array}$ \\
\hline $\begin{array}{l}\text { Number of Loans } \\
\text { Adjusted R-squared }\end{array}$ & $\begin{array}{c}348,259 \\
0.227\end{array}$ & $\begin{array}{c}348,259 \\
0.0810\end{array}$ & $\begin{array}{c}348,259 \\
0.147\end{array}$ & $\begin{array}{c}348,259 \\
0.042\end{array}$ & $\begin{array}{c}348,259 \\
0.028\end{array}$ \\
\hline
\end{tabular}

Panel B: Heterogeneous Treatment Effects Two Years after Reduction in Mortgage Payments

\begin{tabular}{|c|c|c|c|c|c|}
\hline & $\begin{array}{c}\text { Monthly } \\
\text { Mortgage } \\
\text { Payment }\end{array}$ & $\begin{array}{c}\text { Mortgage } \\
\text { Delinquency } \\
\text { Rate }\end{array}$ & $\begin{array}{c}\text { Revolving } \\
\text { Debt } \\
\text { Balance } \\
\end{array}$ & $\begin{array}{c}\text { Auto } \\
\text { Debt } \\
\text { Balance }\end{array}$ & $\begin{array}{c}\text { Probability of } \\
\text { New Auto } \\
\text { Financing }\end{array}$ \\
\hline Treatment & $\begin{array}{c}-157.38 \\
(9.21)\end{array}$ & $\begin{array}{r}-0.003 \\
(0.00)\end{array}$ & $\begin{array}{c}72.617 \\
(157.102)\end{array}$ & $\begin{array}{c}322.019 \\
(99.16)\end{array}$ & $\begin{array}{c}0.012 \\
(0.004)\end{array}$ \\
\hline Treatment $\times($ FICO $<M)$ & $\begin{array}{l}-8.616 \\
(5.92)\end{array}$ & $\begin{array}{r}-0.030 \\
(0.01)\end{array}$ & $\begin{array}{l}-970.88 \\
(234.58)\end{array}$ & $\begin{array}{l}-251.808 \\
(126.94)\end{array}$ & $\begin{array}{l}-0.003 \\
(0.001)\end{array}$ \\
\hline $\begin{array}{l}\text { Number of Loans } \\
\text { Adjusted R-squared }\end{array}$ & $\begin{array}{c}348,259 \\
0.252\end{array}$ & $\begin{array}{c}348,259 \\
0.076\end{array}$ & $\begin{array}{c}348,259 \\
0.134\end{array}$ & $\begin{array}{c}348,259 \\
0.041\end{array}$ & $\begin{array}{c}348,259 \\
0.04\end{array}$ \\
\hline
\end{tabular}




\section{A5: Distribution of CLTV Ratios}

This table shows distribution of current CLTV ratios (by the percentile of distribution) as of month 48, 60, 72, and 84 of the loan's life for all loans originated in $2006-2007$ period in our sample (Panel A) as well as for 5/1 ARMs (Panel B) and 7/1 ARMs (Panel C).

Panel A: Distribution of CLTV Ratios (All Loans)

\begin{tabular}{cccccc}
\hline \hline Month & 10th & 25th & Median & 75th & 90th \\
\hline 48 & 66.0 & 82.0 & 98.7 & 123.4 & 158.2 \\
60 & 70.0 & 86.3 & 105.6 & 135.1 & 171.3 \\
72 & 69.9 & 86.3 & 106.2 & 134.6 & 168.2 \\
84 & 65.7 & 81.4 & 99.7 & 125.5 & 152.7 \\
\hline \hline
\end{tabular}

Panel B: Distribution of CLTV Ratios (5/1 ARMs)

\begin{tabular}{cccccc}
\hline \hline Month & 10th & 25th & Median & 75th & 90th \\
\hline 48 & 66.8 & 82.7 & 99.1 & 124.4 & 160.9 \\
60 & 70.8 & 86.5 & 106.1 & 136.3 & 174.0 \\
72 & 70.3 & 86.3 & 106.4 & 135.3 & 169.2 \\
84 & 65.7 & 80.9 & 99.4 & 125.2 & 152.6 \\
\hline \hline
\end{tabular}

Panel C: Distribution of CLTV Ratios (7/1 ARMs)

\begin{tabular}{cccccc}
\hline \hline Month & 10th & 25th & Median & 75th & 90th \\
\hline 48 & 62.9 & 79.5 & 97.3 & 119.2 & 148.8 \\
60 & 66.8 & 85.3 & 104.3 & 130.5 & 163.6 \\
72 & 68.0 & 85.9 & 105.9 & 132.4 & 164.1 \\
84 & 65.1 & 83.0 & 102.2 & 126.7 & 152.8 \\
\hline \hline
\end{tabular}




\section{A6: Impact of Mortgage Payment Reduction in a Sample of Borrowers Unlikely to Prepay}

This table presents results for the difference-in-difference OLS specifications to examine the differential outcomes for 5/1 ARM contracts relative to 7/1 ARM contracts after the $5 / 1$ contracts' first reset date. The sample is restricted to only those loans with estimated below-median propensities to prepay (based on a prediction from a regression of which loans prepay by their $48^{\text {th }}$ month). Panel A presents outcomes one year after the first rate reset, while Panel B presents similar results two years after the first reset (but before the 7/1 rate reset). The coefficient of interest, Treatment, is the estimated change in the difference between outcomes of 5/1 ARM and 7/1 ARM contract types during the period after the reset date. Thus, this coefficient captures the differential effect of mortgage rate decline (due to a reset) on outcomes of mortgages subject to a reset (5/1 ARM contracts) relative to outcomes of mortgages that did not experience a change in interest rate (7/1 ARM contracts). The specifications include a rich set of observable characteristics as control variables including loan age and mortgage product dummies, rate at origination, FICO credit score, CLTV, quarter-year origination fixed effects and state fixed effects. Standard errors clustered by quarter of origination are in parentheses.

Panel A: One Year after Mortgage Payment Reduction

\begin{tabular}{|c|c|c|c|c|c|c|c|c|}
\hline & $\begin{array}{c}\text { Monthly } \\
\text { Interest } \\
\text { Rate } \\
\end{array}$ & $\begin{array}{c}\text { Monthly } \\
\text { Mortgage } \\
\text { Payment }\end{array}$ & $\begin{array}{c}\text { Mortgage } \\
\text { Delinquency } \\
\text { Rate } \\
\end{array}$ & $\begin{array}{c}\text { Revolving } \\
\text { Debt } \\
\text { Balance } \\
\end{array}$ & $\begin{array}{c}\text { Auto } \\
\text { Debt } \\
\text { Balance }\end{array}$ & $\begin{array}{c}\text { Probability of } \\
\text { New Auto } \\
\text { Financing } \\
\end{array}$ & $\begin{array}{c}\text { Recent } \\
\text { Credit } \\
\text { Inquiries } \\
\end{array}$ & $\begin{array}{c}\text { Current } \\
\text { Credit Score } \\
\text { (FICO) }\end{array}$ \\
\hline Treatment & $\begin{array}{l}-1.01 \\
(0.31)\end{array}$ & $\begin{array}{r}-109.80 \\
(22.57)\end{array}$ & $\begin{array}{c}-0.005 \\
(0.004)\end{array}$ & $\begin{array}{c}-22.30 \\
(102.44)\end{array}$ & $\begin{array}{c}146.58 \\
(52.19)\end{array}$ & $\begin{array}{c}0.002 \\
(0.003)\end{array}$ & $\begin{array}{c}0.045 \\
(0.022)\end{array}$ & $\begin{array}{l}-0.24 \\
(0.85)\end{array}$ \\
\hline Number of Loans & 174,129 & 174,129 & 174,129 & 174,129 & 174,129 & 174,129 & 174,129 & 174,129 \\
\hline Adjusted R-squared & 0.520 & 0.187 & 0.056 & 0.070 & 0.042 & 0.004 & 0.084 & 0.367 \\
\hline
\end{tabular}

Panel B: Two Years after Mortgage Payment Reduction

\begin{tabular}{|c|c|c|c|c|c|c|c|c|}
\hline & $\begin{array}{c}\text { Monthly } \\
\text { Interest } \\
\text { Rate } \\
\end{array}$ & $\begin{array}{c}\text { Monthly } \\
\text { Mortgage } \\
\text { Payment }\end{array}$ & $\begin{array}{c}\text { Mortgage } \\
\text { Delinquency } \\
\text { Rate } \\
\end{array}$ & $\begin{array}{c}\text { Revolving } \\
\text { Debt } \\
\text { Balance } \\
\end{array}$ & $\begin{array}{c}\text { Auto } \\
\text { Debt } \\
\text { Balance } \\
\end{array}$ & $\begin{array}{c}\text { Probability of } \\
\text { New Auto } \\
\text { Financing } \\
\end{array}$ & $\begin{array}{c}\text { Recent } \\
\text { Credit } \\
\text { Inquiries } \\
\end{array}$ & $\begin{array}{c}\text { Current } \\
\text { Credit Score } \\
\text { (FICO) }\end{array}$ \\
\hline Treatment & $\begin{array}{l}-1.58 \\
(0.14)\end{array}$ & $\begin{array}{c}-146.97 \\
(9.83)\end{array}$ & $\begin{array}{c}-0.013 \\
(0.005)\end{array}$ & $\begin{array}{l}-247.81 \\
(95.607)\end{array}$ & $\begin{array}{l}173.79 \\
(62.66)\end{array}$ & $\begin{array}{c}0.010 \\
(0.002)\end{array}$ & $\begin{array}{c}-0.106 \\
(0.019)\end{array}$ & $\begin{array}{c}5.00 \\
(1.26)\end{array}$ \\
\hline Number of Loans & 174,129 & 174,129 & 174,129 & 174,129 & 174,129 & 174,129 & 174,129 & 174,129 \\
\hline Adjusted R-squared & 0.891 & 0.210 & 0.051 & 0.066 & 0.041 & 0.004 & 0.085 & 0.351 \\
\hline
\end{tabular}




\section{A7: Impact of Mortgage Payment Reduction on New Durable Consumption (Auto) Financing among Agency and Non-Agency Borrowers}

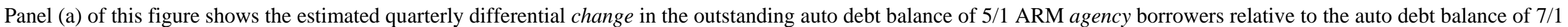

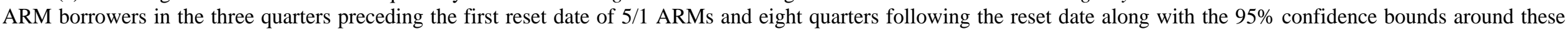

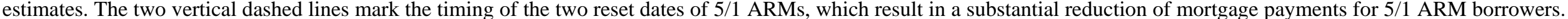

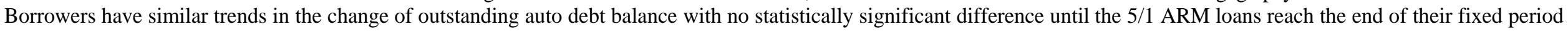

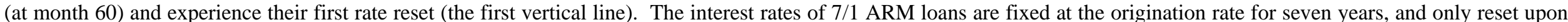

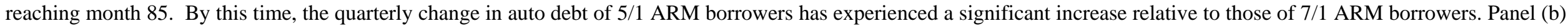

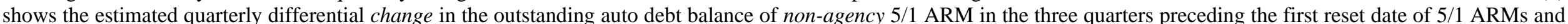

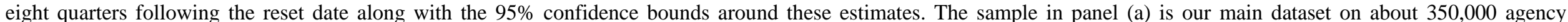

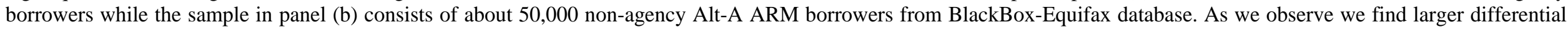

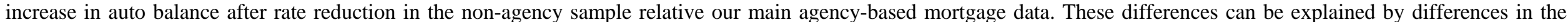
borrower characteristics, loan amounts, and contract terms across these two samples of borrowers (see Section IV.E for more discussion).

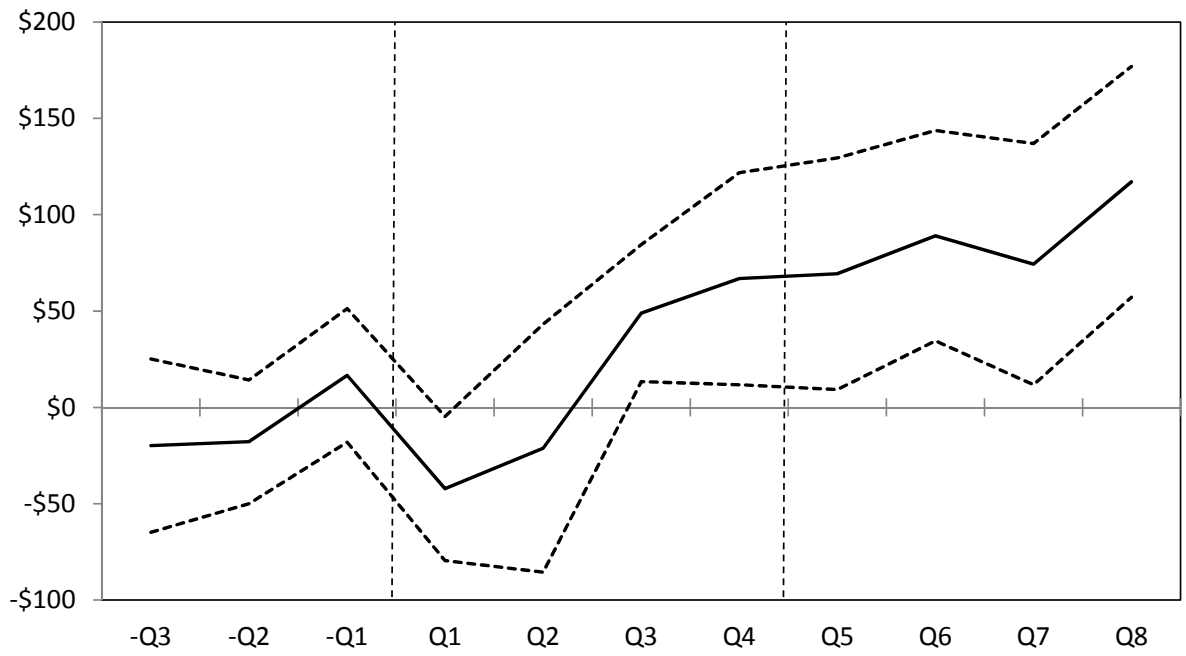

(a) Quarterly Differential Change in Auto Debt Balance Borrowers with Agency Mortgages

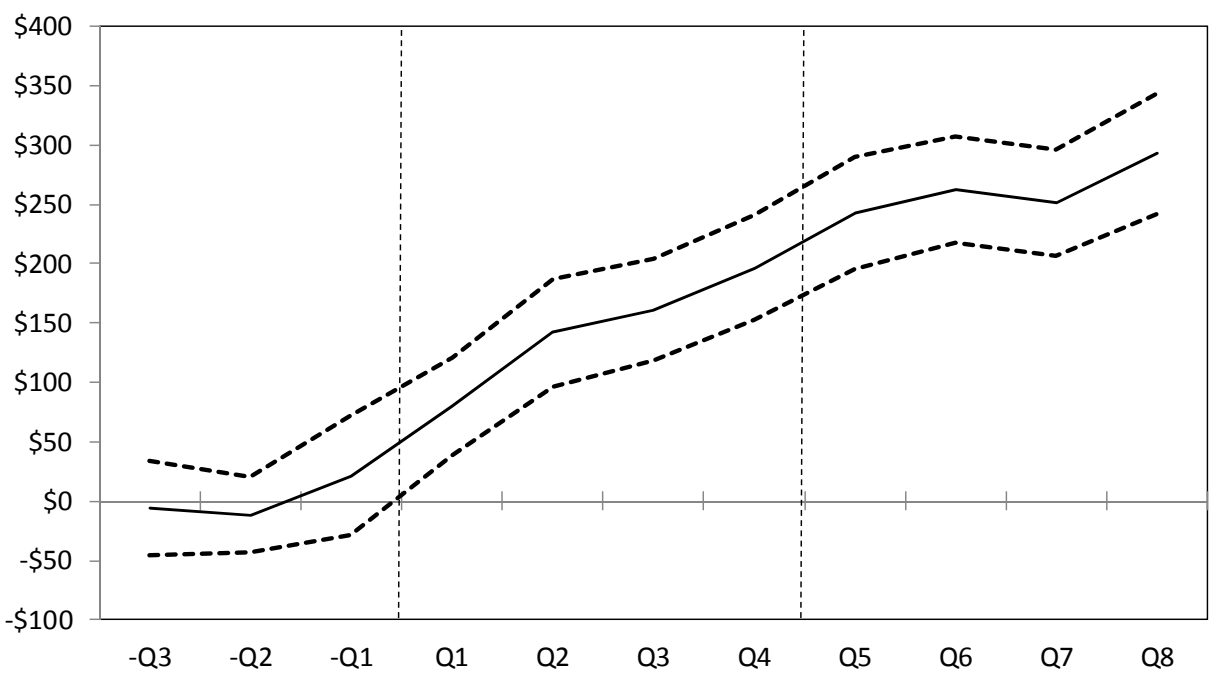

(b) Quarterly Differential Change in Auto Debt Balance Borrowers with Non-Agency Mortgages 


\section{A8: Instrumental Variable Analysis:}

\section{Mortgage Delinquency, House Prices, Auto Sales Growth, and the Zip Code Change in Mortgage Interest Rates}

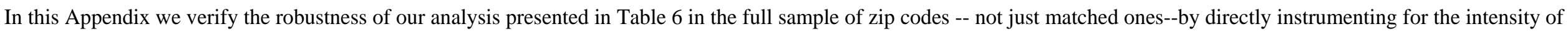

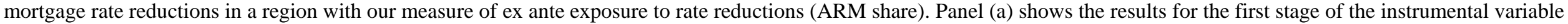

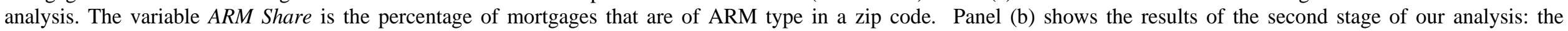

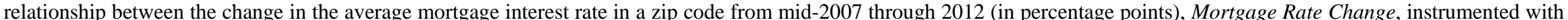

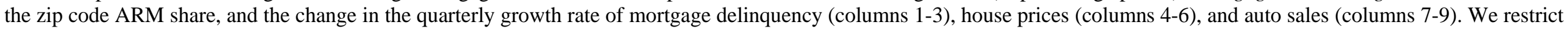

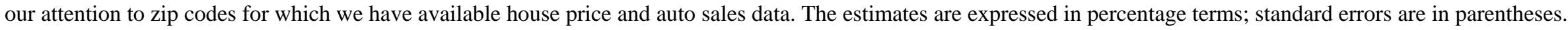

Panel A: Zip Code ARM Share and Change in a Zip Code Mortgage Interest Rate (First Stage)

\begin{tabular}{lccc}
\hline \hline & $(1)$ & $(2)$ & $(3)$ \\
\hline ARM Share & $\mathbf{- 0 . 0 2 0 9}$ & $\mathbf{- 0 . 0 2 0 1}$ & $\mathbf{- 0 . 0 1 9 8}$ \\
& $\mathbf{( 0 . 0 0 0 2 )}$ & $\mathbf{( 0 . 0 0 0 2 )}$ & $\mathbf{( 0 . 0 0 0 3 )}$ \\
Zip Code Controls & No & Yes & Yes \\
State FE & No & No & Yes \\
\hline Number of Zip Codes & 8084 & 7488 & 7488 \\
R-Squared & 0.571 & 0.711 & 0.728 \\
\hline \hline
\end{tabular}

Panel B: Change in the Mortgage Delinquency, House Price, and Auto Sales Growth Rate and the Zip Code Change in Mortgage Interest Rate

\begin{tabular}{|c|c|c|c|c|c|c|c|c|c|}
\hline & \multicolumn{3}{|c|}{ Mortgage Delinquency Growth } & \multicolumn{3}{|c|}{ House Price Growth } & \multicolumn{3}{|c|}{ Auto Sale Growth } \\
\hline & $(1)$ & $(2)$ & (3) & $(4)$ & $(5)$ & (6) & $(7)$ & $(8)$ & (9) \\
\hline \multirow[t]{2}{*}{ Mortgage Rate Change } & 28.93 & 30.17 & 18.08 & -0.39 & -1.36 & -0.79 & -2.70 & -4.38 & -1.26 \\
\hline & $(0.82)$ & (1.07) & (1.31) & $(0.07)$ & $(0.09)$ & $(0.10)$ & $(0.15)$ & $(0.22)$ & $(0.27)$ \\
\hline Zip Code Controls & No & Yes & Yes & No & Yes & Yes & No & Yes & Yes \\
\hline State FE & No & No & Yes & No & No & Yes & No & No & Yes \\
\hline Number of Zip Codes & 8082 & 7487 & 7487 & 8000 & 7487 & 7487 & 8084 & 7488 & 7488 \\
\hline Adjusted R-squared & 0.091 & 0.222 & 0.341 & 0.05 & 0.197 & 0.429 & 0.020 & 0.042 & 0.185 \\
\hline
\end{tabular}

